\title{
NF1 regulates mesenchymal glioblastoma plasticity and aggressiveness through the AP-1 transcription factor FOSL1
}

\section{Carolina Marques ${ }^{1}$, Thomas Unterkircher ${ }^{2}$, Paula Kroon ${ }^{1}$, Barbara Oldrini ${ }^{1}$, Annalisa Izzo일. Yuliia Dramaretska ${ }^{3}$, Roberto Ferrarese ${ }^{2}$, Eva Kling ${ }^{2}$, Oliver Schnell ${ }^{2}$, Sven Nelander ${ }^{4,5}$, Erwin F Wagner ${ }^{6,7,8}$, Latifa Bakiri, ${ }^{6,7}$, Gaetano Gargiulo ${ }^{3}$, Maria Stella Carro ${ }^{2 *}$, Massimo Squatrito ${ }^{1 *}$}

${ }^{1}$ Seve Ballesteros Foundation Brain Tumor Group, Spanish National Cancer Research Centre, Madrid, Spain; ${ }^{2}$ Department of Neurosurgery, Faculty of Medicine Freiburg, Freiburg, Germany; ${ }^{3}$ Max-Delbrück-Center for Molecular Medicine in the Helmholtz Association (MDC), Berlin, Germany; ${ }^{4}$ Dept of Immunology, Genetics and Pathology and Science for Life Laboratory, Uppsala University, Rudbecklaboratoriet, Uppsala, Sweden; ${ }^{5}$ Science for Life Laboratory, Uppsala University, Rudbecklaboratoriet, Uppsala, Sweden; 'Genes, Development, and Disease Group, Spanish National Cancer Research Centre, Madrid, Spain; ${ }^{7}$ Laboratory Medicine Department, Medical University of Vienna, Vienna, Austria; ${ }^{8}$ Dermatology Department, Medical University of Vienna, Vienna, Austria
*For correspondence:

Correspondence: maria.carro@ uniklinik-freiburg.de;

msquatrito@cnio.es

Competing interests: The authors declare that no competing interests exist.

Funding: See page 30

Preprinted: 07 November 2019 Received: 12 November 2020 Accepted: 18 July 2021 Published: 17 August 2021

Reviewing editor: Arezu JahaniAsl, McGill University, Canada

(c) Copyright Marques et al. This article is distributed under the terms of the Creative Commons Attribution License, which permits unrestricted use and redistribution provided that the original author and source are credited.
Abstract The molecular basis underlying glioblastoma (GBM) heterogeneity and plasticity is not fully understood. Using transcriptomic data of human patient-derived brain tumor stem cell lines (BTSCs), classified based on GBM-intrinsic signatures, we identify the AP-1 transcription factor FOSL1 as a key regulator of the mesenchymal (MES) subtype. We provide a mechanistic basis to the role of the neurofibromatosis type 1 gene (NF1), a negative regulator of the RAS/MAPK pathway, in GBM mesenchymal transformation through the modulation of FOSL1 expression. Depletion of FOSL1 in NF1-mutant human BTSCs and Kras-mutant mouse neural stem cells results in loss of the mesenchymal gene signature and reduction in stem cell properties and in vivo tumorigenic potential. Our data demonstrate that FOSL1 controls GBM plasticity and aggressiveness in response to NF1 alterations.

\section{Introduction}

Gliomas are the most common primary brain tumor in adults. Given the strong association of the isocitrate dehydrogenase 1 and 2 (IDH1/2) genes mutations with glioma patients survival, the 2016 WHO classification, which integrates both histological and molecular features, has introduced the distinction of IDH-wildtype (IDH-wt) or IDH-mutant (IDH-mut) in diffuse gliomas (Louis et al., 2016). IDH-wt glioblastoma (GBM) represents the most frequent and aggressive form of gliomas, characterized by high molecular and cellular inter- and intra-tumoral heterogeneity.

Large-scale sequencing approaches have evidenced how concurrent perturbations of cell cycle regulators, growth and survival pathways, mediated by RAS/MAPK and PI3K/AKT signaling, play a significant role in driving adult GBMs (Brennan et al., 2013; Cancer Genome Atlas Research Network, 2008; Verhaak et al., 2010). Moreover, various studies have classified GBM in different subtypes, using transcriptional profiling, being now the proneural (PN), classical (CL), and mesenchymal (MES) the most widely accepted (Phillips et al., 2006; Verhaak et al., 2010; Wang et al., 2017). 
Patients with the MES subtype tend to have worse survival rates compared to other subtypes, both in the primary and recurrent tumor settings (Wang et al., 2017). The most frequent genetic alterations - neurofibromatosis type 1 gene (NF1) copy number loss or mutation - and important regulators of the MES subtype, such as STAT3, CEBPB, and TAZ, have been identified (Bhat et al., 2011; Carro et al., 2010; Verhaak et al., 2010). Nevertheless, the mechanisms of regulation of MES GBMs are still not fully understood. For example, whether the MES transcriptional signature is controlled through tumor cell-intrinsic mechanisms or influenced by the tumor microenvironment (TME) is still an unsolved question. In fact, the critical contribution of the TME adds another layer of complexity to MES GBMs. Tumors from this subtype are highly infiltrated by non-neoplastic cells as compared to PN and CL subtypes (Wang et al., 2017). Additionally, MES tumors express high levels of angiogenic markers and exhibit high levels of necrosis (Cooper et al., 2012).

Even though each subtype is associated with specific genetic alterations, there is a considerable plasticity among them: different subtypes coexist in the same tumors and shifts in subtypes can occur over time (Patel et alo, 2014; Sottoriva et al., 2013). This plasticity may be explained by acquisition of new genetic and epigenetic abnormalities, stem-like reprogramming, or clonal variation (Fedele et al., 2019). It is also not fully understood whether the distinct subtypes evolve from a common glioma precursor (Ozawa et al., 2014). For instance, PN and CL tumors often switch phenotype to MES upon recurrence, and treatment also increases the mesenchymal gene signature, suggesting that MES transition, or epithelial to mesenchymal (EMT)-like, in GBM is associated with tumor progression and therapy resistance (Bhat et al., 2013; Halliday et al., 2014; Phillips et al., 2006). Yet, the frequency and relevance of this EMT-like phenomenon in glioma progression remains unclear. EMT has also been associated with stemness in other cancers (Mani et al., 2008; Tam and Weinberg, 2013; Ye et al., 2015). Glioma stem cells (GSCs) share features with normal neural stem cells (NSCs) such as self-renewal and ability to differentiate into distinct cellular lineages (astrocytes, oligodendrocytes, and neurons) but are thought to be responsible for tumor relapse, given their ability to repopulate tumors and their resistance to treatment (Bao et al., 2006; Chen et al., 2012). GSCs heterogeneity is also being increasingly observed (Bhat et al., 2013; Mack et al., 2019; Richards et al., 2021), but whether genotype-to-phenotype connections exist remain to be clarified.

FOSL1, which encodes FRA-1, is an AP-1 transcription factor (TF) with prognostic value in different epithelial tumors, where its overexpression correlates with tumor progression or worse patient survival (Chiappetta et alı, 2007; Gao et alı, 2017; Usui et alı, 2012; Vallejo et al., 2017; Wu et al., 2015; Xu et al., 2017). Moreover, the role of FOSL1 in EMT has been documented in breast and colorectal cancers (Andreolas et al., 2008; Bakiri et al., 2015; Diesch et al., 2014). In GBM, it has been shown that FOSL1 modulates in vitro glioma cell malignancy (Debinski and Gibo, 2005).

Here we report that NF1 loss, by increasing RAS/MAPK activity, modulates FOSL1 expression, which in turn plays a central function in the regulation of MES GBM. Using a surrogate mouse model of MES GBM and patient-derived MES brain tumor stem cells (BTSCs), we show that FOSL1 is responsible for sustaining cell growth in vitro and in vivo, and for the maintenance of stem-like properties. We propose that FOSL1 is an important regulator of GBM stemness, MES features and plasticity, controlling an EMT-like process with therapeutically relevant implications.

\section{Results}

\section{FOSL1 is a key regulator of the MES subtype}

To study the tumor cell-intrinsic signaling pathways that modulate the GBM expression subtypes, we assembled a collection of transcriptomic data (both expression arrays and RNA-sequencing) of 144 samples derived from 116 independent BTSC lines (see Materials and methods for details). Samples were then classified according to the previously reported 50-gene glioma-intrinsic transcriptional subtype signatures and the single-sample gene set enrichment analysis (ssGSEA)-based equivalent distribution resampling classification strategy (Wang et al., 2017). Principal component analysis (PCA) showed a large overlap of the transcription profile among BTSCs classified either as CL/PN while most of the MES appeared as separate groups (Figure 1A and Supplementary file 1). This separation is consistent with early evidence in GSCs (Bhat et al., 2013) and holds $92 \%$ of concordance in the identification of a recent two transcriptional subgroups classification of single-GSCs 
A

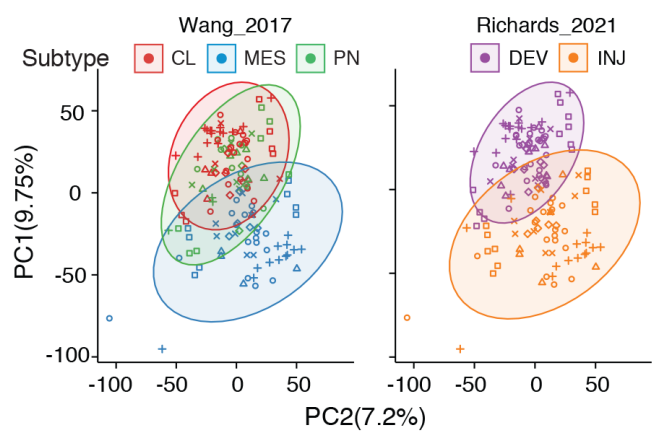

C

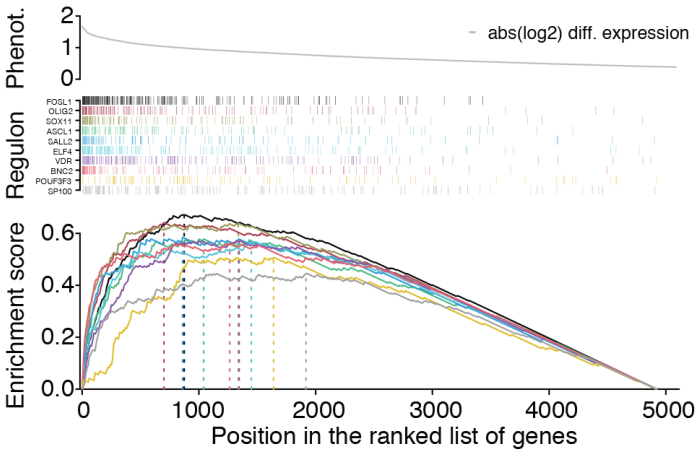

E

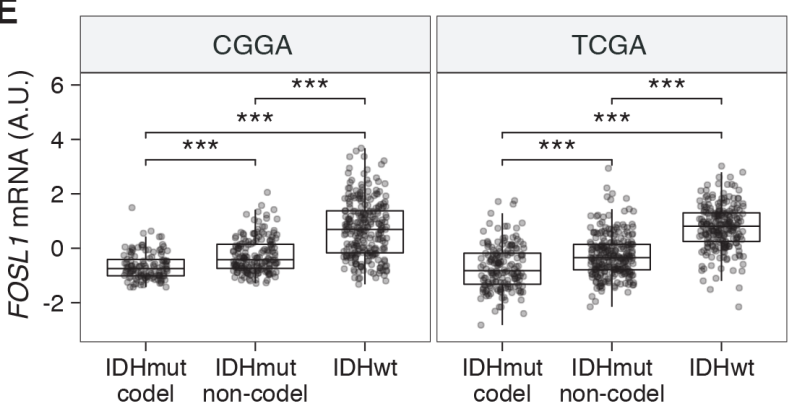

B

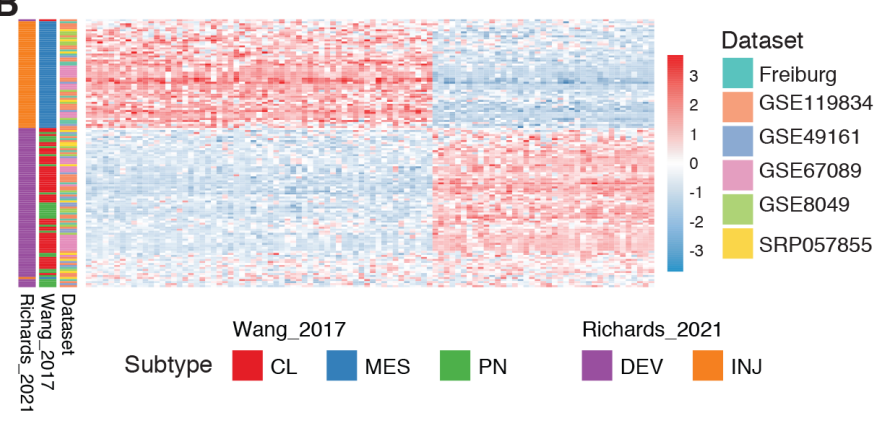

D

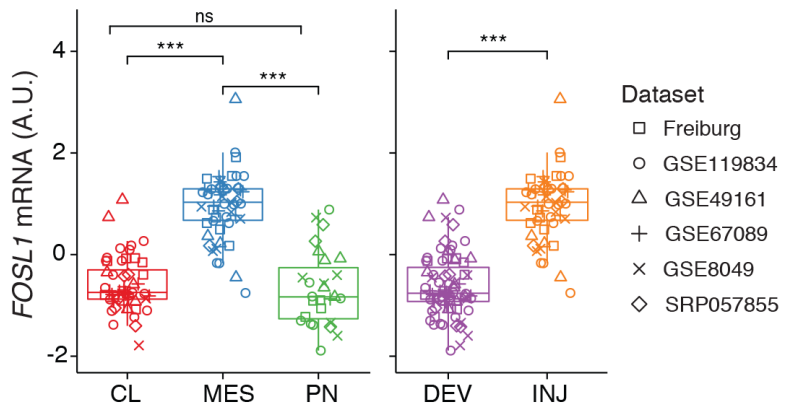

F

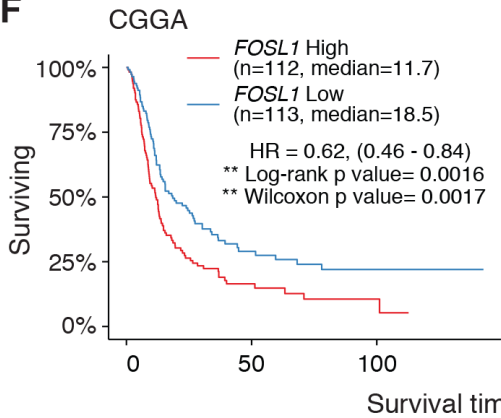

TCGA

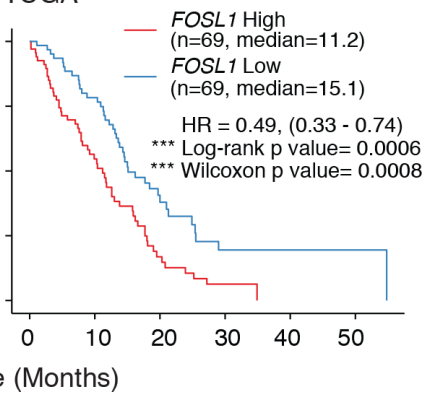

Figure 1. FOSL1 is a bona fide regulator of the glioma-intrinsic mesenchymal (MES) transcriptional signature. (A) Principal component (PC) analysis of the brain tumor stem cells (BTSCs) expression dataset. (B) Heatmap of the top 100 differentially expressed genes between MES and non-MES BTSCs. (C) One-tail gene set enrichment analysis (GSEA) of the top 10 scoring transcription factors (TFs) in the master regulator analysis (MRA). (D) FOSL1 mRNA expression in the BTSCs dataset. One-way ANOVA with Tukey multiple pairwise comparison, ${ }^{\star \star *} \mathrm{p} \leq 0.001$, ns $=$ not significant. (E) FOSL1 mRNA expression in the CGGA and TCGA datasets. Tumors were separated according to their molecular subtype classification. One-way ANOVA with Tukey multiple pairwise comparison, ${ }^{\star \star \star} p \leq 0.001$. (F) Kaplan-Meier survival curves of IDH-wt gliomas in the CGGA and TCGA datasets stratified based on FOSL1 expression (see Materials and methods for details).

The online version of this article includes the following source data and figure supplement(s) for figure 1:

Source data 1. Source data of Figure 1A, B, D-F.

Figure supplement 1. Expression, bulk and single-cell RNA-seq, of the top 10 transcription factors (TFs) identified in the master regulator analysis (MRA).

Figure supplement 1-source data 1. Source data of Figure 1-figure supplement 1A, C, D, and E.

Figure supplement 2. Expression in human glioblastomas (GBMs) of FOSL1 and the top 10 transcription factors (TFs) identified in the master regulator analysis (MRA).

Figure supplement 2-source data 1. Source data of Figure 1-figure supplement 2A-C.

defined as developmental (DEV) and injury response (INJ) (Richards et al., 2021). Differential gene expression analysis comparing mesenchymal versus non-mesenchymal BTSCs confirmed the clear separation among the two groups, with only a minor fraction of cell lines showing a mixed 
expression profile (Figure 1B and Supplementary file 2), further supporting that GSCs exist along a major transcriptional gradient between two cellular states (Bhat et al., 2013; Richards et al., 2021).

To reveal the signaling pathways underlying the differences between MES and non-MES BTSCs, we then applied a network-based approach based on the Algorithm for the Reconstruction of Accurate Cellular Networks (ARACNe) (Basso et al., 2005; Carro et al., 2010), which identifies a list of TFs with their predicted targets, defined as regulons. The regulon for each TF is constituted by all the genes whose expression data exhibit significant mutual information with that of a given TF and are thus expected to be regulated by that TF (Castro et al., 2016; Fletcher et al., 2013). Enrichment of a relevant gene signature in each of the regulons can point to the TFs acting as master regulators (MRs) of the response or phenotype (Carro et al., 2010; Fletcher et al., 2013). Master regulator analysis (MRA) identified a series of TFs, among which FOSL1, VDR, OLIG2, SP100, ELF4, SOX11, BNC2, ASCL1, SALL2, and POU3F3 were the top 10 most statistically significant (BenjaminiHochberg $\mathrm{p}<0.0001$ ) (Figure $1 \mathrm{C}$ and Supplementary file 3). FOSL1, VDR, SP100, ELF4, and BNC2 were significantly upregulated in the MES BTSCs, while OLIG2, SOX11, ASCL1, SALL2, and POU3F3 were upregulated in the non-MES BTSCs (Figure 1D and Figure 1-figure supplement 1A). Gene set enrichment analysis (GSEA) evidenced how the regulons for the top 10 TFs are enriched for genes that are differentially expressed among the two classes (MES and non-MES) with FOSL1 having the highest enrichment score (Figure 1C, Figure 1-figure supplement 1B, and Supplementary file 3). Lastly, an analysis of an independent BTSCs dataset (Richards et al., 2021) evidenced that the differential expression of FOSL1 and the other TFs was maintained both at bulk (Figure 1-figure supplement 1C) and at a single-cell level (Figure 1-figure supplement 1D, E).

We then analyzed the CGGA and TCGA pan-glioma datasets (Ceccarelli et al., 2016; Zhao et al., 2017) and observed that FOSL1 expression is elevated in the IDH-wt glioma molecular subgroup (Figure 1E and Supplementary file 4) with a significant upregulation in the MES subtype in bulk tumors, and it is also enriched in MES-like cells (Neftel et al., 2019) at the single-cell level (Figure 1-figure supplement 2A-C). Importantly, high expression levels were associated with worse prognosis in IDH-wt tumors (Figure 1F), thus suggesting that FOSL1 could represent not only a key regulator of the glioma-intrinsic MES signature, but also a putative key player in MES glioma pathogenesis.

\section{NF1 modulates the MES signature and FOSL1 expression}

NF1 alterations and activation of the RAS/MAPK signaling have been previously associated with the MES GBM subtype (Brennan et al., 2013; Verhaak et al., 2010; Wang et al., 2016; Wang et al., 2017). However, whether NF1 plays a broader functional role in the regulation of the MES gene signature (MGS) in IDH-wt gliomas still remains to be established.

We initially grouped, according to the previously described GBM subtype-specific gene signatures, a subset of IDH-wt glioma samples of the TCGA dataset for which RNA-seq data were available $(n=229$ ) (see Materials and methods for details). By analyzing the frequency of NF1 alterations (either point mutations or biallelic gene loss), we confirmed a significant enrichment of NF1 alterations in MES versus non-MES tumors (Fisher's exact test $p=0.0106$ ) (Figure 2A, B). Importantly, we detected higher level of FOSL1 mRNA in the cohort of IDH-wt gliomas with NF1 alterations (Student's t test $p=0.018$ ) (Figure $2 C$ ), as well as a significant negative correlation between FOSL1 and NF1 mRNA levels (Pearson $R=-0.44, p=7.8 e-12$ ) (Figure 2D and Supplementary file 4).

To test whether a NF1-MAPK signaling is involved in the regulation of FOSL1 and the MES subtype, we manipulated NF1 expression in patient-derived GBM tumorspheres of either MES or nonMES subtypes. To recapitulate the activity of the full-length NF1 protein, we transduced the cells with the NF1 GTPase-activating domain (NF1-GRD), spanning the whole predicted Ras GTPaseactivating (GAP) domain (McCormick, 1990). NF1-GRD expression in the MES cell line BTSC 233 led to (i) inhibition of RAS activity as confirmed by analysis of pERK expression upon EGF or serum stimulation (Figure 2-figure supplement 1A, B) as well as by RAS pull-down assay (Figure 2-figure supplement 1C); (ii) strong reduction of a RAS-induced oncogenic signature expression (NES = -1.7; FDR q-value < 0.001) (Figure 2-figure supplement 1D); and (iii) diminished cell proliferation (Figure 2-figure supplement 1E, F). Consistent with the negative correlation of FOSL1 and NF1 mRNA levels in IDH-wt gliomas (Figure 2D), NF1-GRD overexpression in two independent MES GBM lines (BTSC 233 and BTSC 232) was associated with a significative downregulation of FOSL1 and FOSL1-regulated genes (Figure 2E and Figure 2-figure supplement 2A-C). Concurrently, we 
A

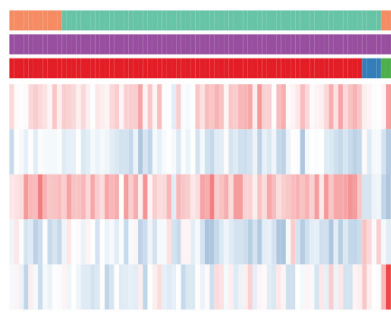

Wang_2017

$\square \mathrm{CL} \square$ MES $\square$ PN

C

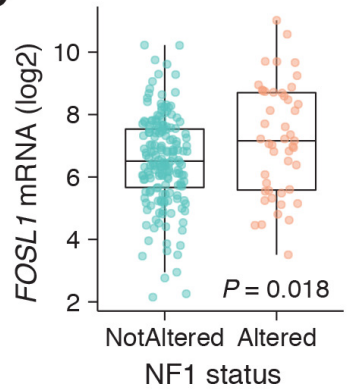

D

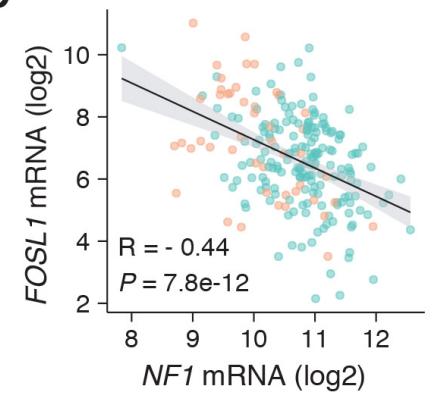

E

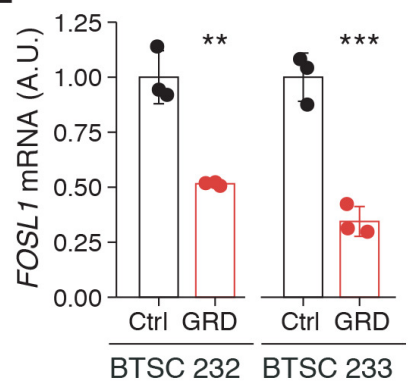

B

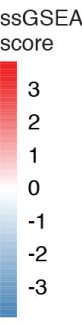

Richards_2021

DEV IINJ
NF1_status

Altered $\square$ NotAltered $\square$ Unknown
Fisher's exact test:

$P$ value $=0.0106$

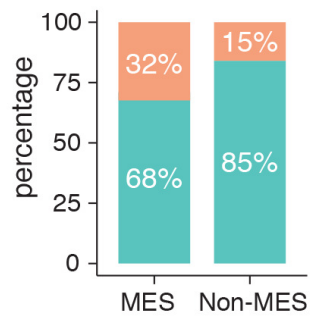

$\mathbf{F}$

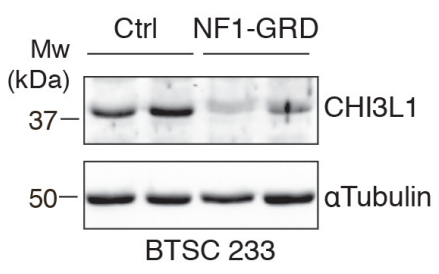

G

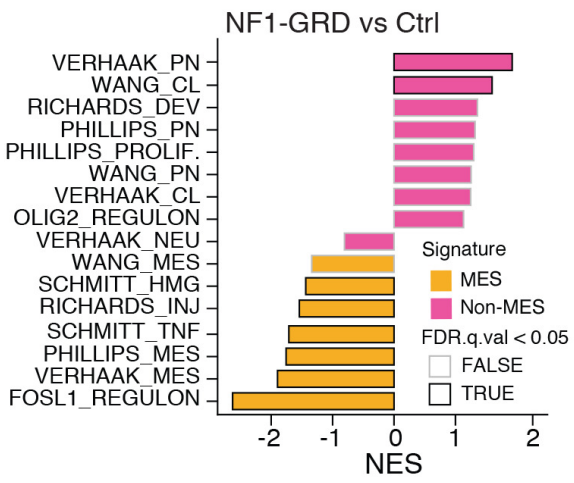

$\mathrm{H}$

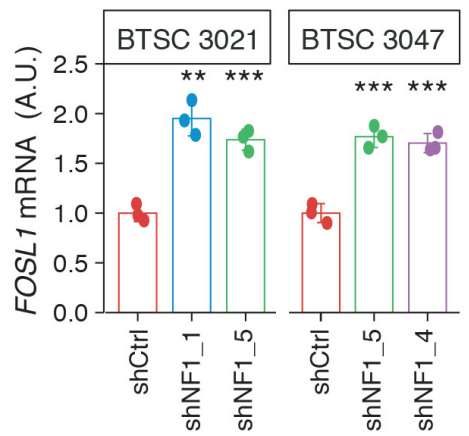

I

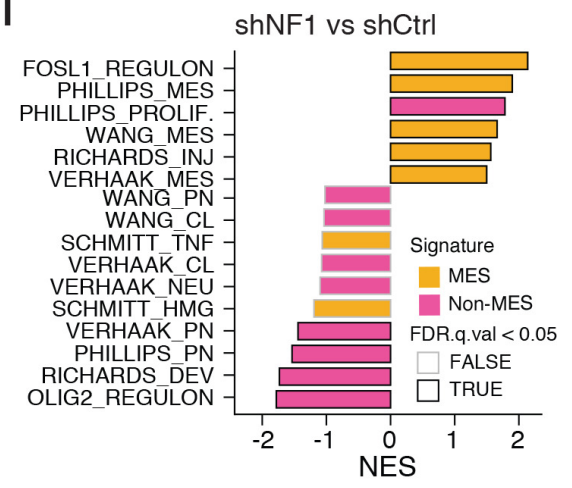

J
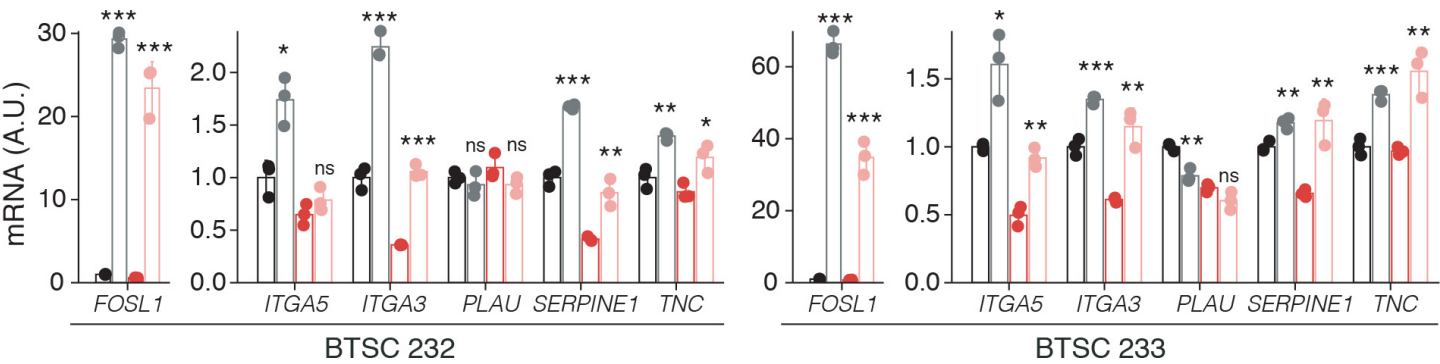

Sample

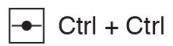

$\rightarrow$ Ctrl + FOSL1

$\bullet N F 1-G R D+$ Ctrl

$\rightarrow$ NF1-GRD + FOSL1

Figure 2. NF1 is a functional modulator of mesenchymal (MES) transcriptional signatures through FOSL1 expression regulation. (A) Heatmap of the subtypes single-sample gene set enrichment analysis (ssGSEA) scores and NF1 genetic alterations of the IDH-wt gliomas in the TCGA dataset. (B) Frequency of NF1 alterations in MES and non-MES IDH-wt gliomas. Colors are as in panel (A). (C) FOSL1 mRNA expression in IDH-wt gliomas, stratified according to NF1 alterations. Colors are as in panel (A). Student's t test, $p=0.018$. (D) Correlation of FOSL1 and NF1 mRNA expression in IDH-wt gliomas. Colors are as in panel (A). Pearson correlation, $R=-0.044, p=7.8 e-12$. (E) qRT-PCR analysis of FOSL1 expression upon NF1-GRD overexpression in BTSC 232 and BTSC 233 cells. (F) Western blot analysis of whole-cell extract of BTSC 233 cells showing CHI3L1 mesenchymal marker expression upon NF1-GRD transduction; $\alpha$-tubulin was used as loading control. Two biological replicates are shown. (G) Gene set enrichment analysis (GSEA) results of BTSC 233 cells transduced with NF1-GRD expressing lentivirus versus Ctrl. NES: normalized enrichment score. (H) qRT-PCR analysis of FOSL1 expression upon NF1 knockdown in BTSC 3021 and BTSC 3047 cells. (I) GSEA results of BTSC 3021 transduced with shNF1_5 versus Figure 2 continued on next page 
Figure 2 continued

Ctrl. (J) qRT-PCR analysis of MES genes expression upon NF1-GRD and FOSL1 co-expression in BTSC 232 and BTSC 233 cells. qRT-PCR data in (E), (H), and $(\mathrm{J})$ are presented as mean $\pm \mathrm{SD}\left(\mathrm{n}=3\right.$, technical replicates), normalized to $18 \mathrm{~S}$ rRNA expression; Student's $t$ test, ${ }^{\star} p \leq 0.05$, ${ }^{\star *} \mathrm{p} \leq 0.01,{ }^{* \star *} \mathrm{p} \leq 0.001$, ns $=$ not significant.

The online version of this article includes the following source data and figure supplement(s) for figure 2:

Source data 1. Source data of Figure 2F.

Source data 2. Source data of Figure 2A, C-E, G-J.

Figure supplement 1. NF1-GRD expression leads to downregulation of RAS signaling.

Figure supplement 1-source data 1. Source data of Figure 2-figure supplement 1A.

Figure supplement 1-source data 2. Source data of Figure 2-figure supplement 1C.

Figure supplement 2. Modulation of NF1 expression regulates FOSL1 targets and mesenchymal genes.

Figure supplement 2-source data 1. Source data of Figure 2-figure supplement 2A.

Figure supplement 2-source data 2. Source data of Figure 2-figure supplement 2E.

Figure supplement 2-source data 3. Source data of Figure 2-figure supplement 2J.

Figure supplement 2-source data 4. Source data of Figure 2-figure supplement 2C, G-I.

Figure supplement 3. MAPK inhibition reverts the effects of NF1 silencing on FOSL1 and mesenchymal genes expression.

Figure supplement 3-source data 1. Source data of Figure 2-figure supplement 3A.

Figure supplement 3-source data 2. Source data of Figure 2-figure supplement 3C.

Figure supplement 3-source data 3. Source data of Figure 2-figure supplement 3E.

Figure supplement 3-source data 4. Source data of Figure 2-figure supplement 3B, D, F, and G.

also observed a significant decrease of two well-characterized mesenchymal features, namely CHI3L1 expression (Figure 2F) as well as the ability of MES GBM cells to differentiate into osteocytes, a feature shared with mesenchymal stem cells (Ricci-Vitiani et al., 2008; Tso et al., 2006; Figure 2-figure supplement 2D). Moreover, NF1-GRD expression led to a significant reduction of the FOSL1 regulon and the MGSs, with a concurrent increase of the OLIG2 regulon and the non-MES gene signatures (non-MGSs) (Figure 2G).

Conversely, NF1 knockdown with three independent shRNAs (shNF1_1, shNF1_4, and shNF1_5) in two non-MES lines (BTSC 3021 and BTSC 3047) (Figure 2-figure supplement 2E) led to an upregulation of FOSL1 (Figure 2H), with a concomitant significant increase in its targets (Figure 2-figure supplement 2F, G), an upregulation of the MGSs, and downregulation of the N-MGSs (Figure 2l).

The observed NF1-mediated gene expression changes might be potentially driven by an effect on FOSL1 or other previously described mesenchymal TFs (such as BHLHB2, CEBPB, FOSL2, RUNX1, STAT3, and TAZ;) (Bhat et al., 2011; Carro et al., 2010). Interestingly, only FOSL1, and to some extent CEBPB, was consistently downregulated upon NF1-GRD expression (Figure 2-figure supplement $2 \mathrm{H}$ ) and upregulated following NF1 knockdown (Figure 2-figure supplement 2I). To then test whether FOSL1 was playing a direct role in the NF1-mediated regulation of mesenchymal genes expression, we overexpressed FOSL1 in the MES GBM lines transduced with the NF1-GRD (Figure 2-figure supplement 2J). qRT-PCR analysis showed that FOSL1 was able to rescue the NF1-GRD-mediated downregulation of mesenchymal genes, such as ITGA3, ITGA5, SERPINE1, and TNC (Figure 3J). Lastly, exposure of NF1 silenced cells to the MEK inhibitor GDC-0623, led to a reduction of FOSL1 upregulation, both at the protein and the mRNA levels, as well as to a downregulation of the mesenchymal genes ITGA3 and SERPINE1 (Figure 2-figure supplement 3A, B).

Overall these evidences implicate the NF1-MAPK signaling in the regulation of the MGSs through the modulation of FOSL1 expression.

\section{Fosl1 deletion induces a shift from a MES to a PN gene signature}

To further explore the NF1-MAPK-FOSL1 axis in MES GBM, we used a combination of the RCAS-Tva system with the CRISPR/Cas9 technology, recently developed in our laboratory (Oldrini et al., 2018), to induce Nf1 loss or Kras mutation. Mouse NSCs from hGFAP-Tva; hGFAP-Cre; Trp53 ${ }^{\text {lox; }}$ ROSA26-LSL-Cas9 pups were isolated and infected with viruses produced by DF1 packaging cells transduced with RCAS vectors targeting the expression of Nf1 through shRNA and sgRNA (shNf1 and $s g N f 1)$ or overexpressing a mutant form of Kras (Kras ${ }^{G 12 V}$ ). Loss of NF1 expression was confirmed by western blot, and FRA-1 was upregulated in the two models of Nf1 loss compared to 


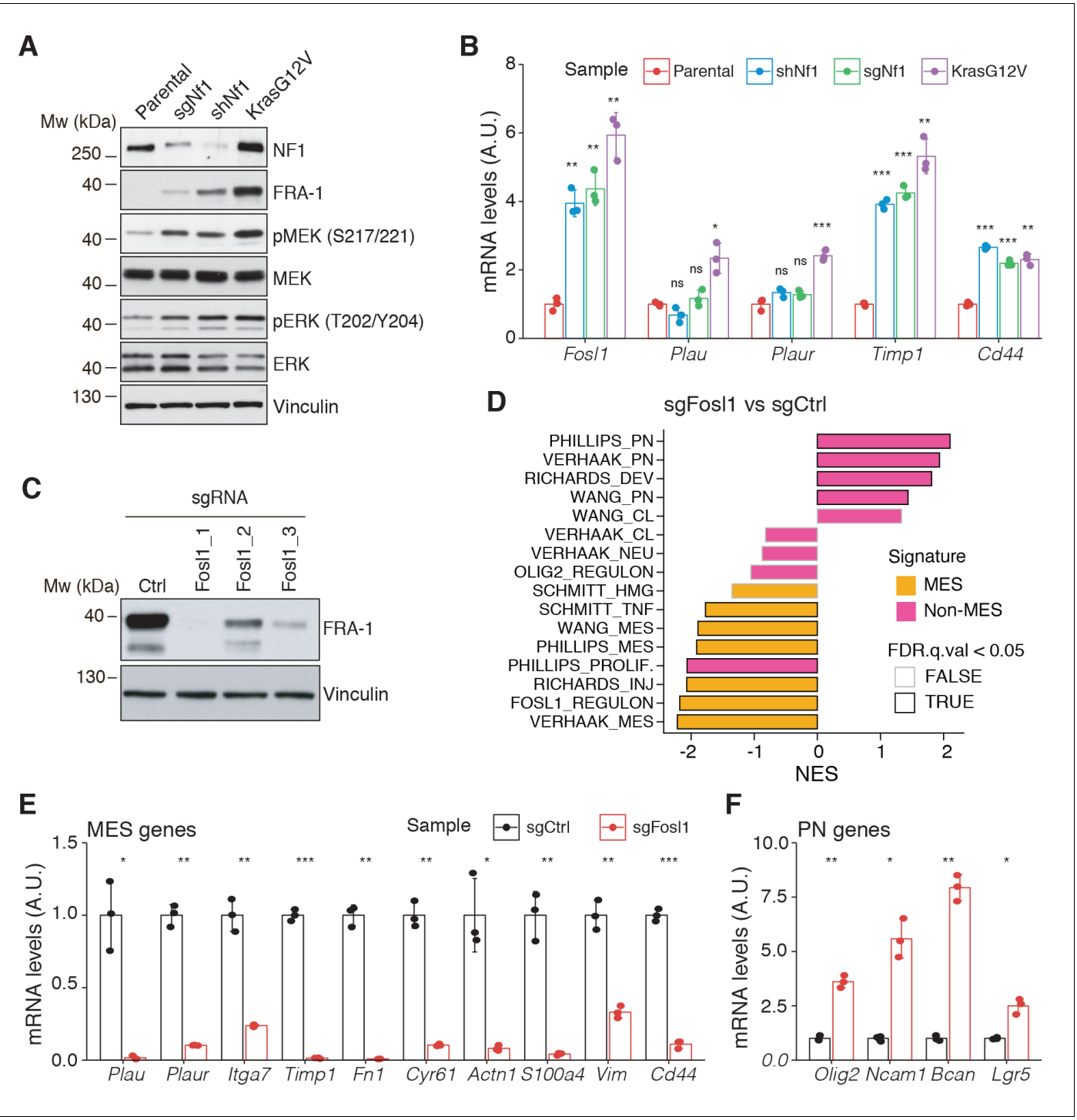

Figure 3. Fos/1 is induced by MAPK kinase activation and is required for mesenchymal (MES) gene expression. (A) Western blot analysis using the specified antibodies of p53-null neural stem cells (NSCs), parental and infected with sgNf1, shNf1, and Kras ${ }^{\text {G12V }}$; vinculin was used as loading control. (B) mRNA expression of Fos/1 and MES genes (Plau, Plaur, Timp1, and Cd44) in infected p53-null NSCs compared to parental cells (not infected). Data from a representative of two experiments are presented as mean \pm SD $(n=3)$, normalized to Gapdh expression. Student's $t$ test, relative to parental cells: ns = not significant, ${ }^{*} p \leq 0.05,{ }^{\star \star} p \leq 0.01,{ }^{\star \star \star} p \leq 0.001$. (C) FRA-1 expression detected by western blot in $p 53-n u l l ~ K r a s{ }^{G 12 V}$ NSCs upon transduction with sgRNAs targeting Fos/1, after selection with $1 \mu \mathrm{g} / \mathrm{mL}$ puromycin; vinculin was used as loading control. (D) Gene set enrichment analysis (GSEA) results of p53-null Kras ${ }^{G 12 V}$ sgFos/1_1 versus sgCtrl NSCs. (E, F) mRNA expression of MES (E) and PN genes (F) in sgCtrl and sgFos/1_1 p53-null Kras ${ }^{G 12 V}$ NSCs. Data from a representative of two experiments are presented as mean \pm SD $(n=3$, technical replicates), normalized to Gapdh expression. Student's t test, relative to sgCtrl: ${ }^{\star} p \leq 0.05 ;{ }^{* \star} p \leq 0.01 ;{ }^{\star \star \star} p \leq 0.001$.

The online version of this article includes the following source data for figure 3 :

Source data 1. Source data of Figure 3A.

Source data 2. Source data of Figure 3C.

Source data 3. Source data of Figure 3B, D-F.

parental cells and further upregulated in cells infected with Kras ${ }^{G 12 V}$ (Figure 3A). Consistent with activation of the Ras signaling, as a result of both Nf1 loss and Kras mutation, the MEK/ERK pathway was more active in infected cells compared to parental cells (Figure 3A). Higher levels of activation of the MEK/ERK pathway were more pronounced in the Kras mutant cells and were associated with a stronger induction of mesenchymal genes such as Plau, Plaur, Timp1, and Cd44 (Figure 3B). 
Moreover, the upregulation of both FRA-1 and the mesenchymal genes was blocked by exposing shNf1 and Kras mutant cells to the MAPK inhibitors trametinib or U0126 (Figure 2-figure supplement 3C, D).

Taking advantage of the Cas9 expression in the generated p53-null NSCs models, Fos/1 was knocked out through sgRNAs. Efficient downregulation of FRA-1 was achieved with two different sgRNAs (Figure 3C and Figure 2-figure supplement 3E). Cells transduced with sgFos/1_1 and sgFosl1_3 were then subjected to further studies.

As suggested by the data presented here on the human BTSCs datasets and cell lines, FOSL1 appears to be a key regulator of the MES subtype. Consistently, RNA-seq analysis followed by GSEA of p53-null Kras ${ }^{G 12 V}$ sgFos/1_1 versus sgCtrl revealed a significant loss of the MGSs and increase in the N-MGSs (Figure 3D). These findings were validated by qRT-PCR with a significant decrease in expression of a panel of MES genes (Plau, Itga7, Timp1, Plaur, Fn1, Cyr61, Actn1, S100a4, Vim, Cd44) (Figure 3E) and increased expression of PN genes (Olig2, Ncam1, Bcan, Lgr5) in the Fosl1 knock-out (KO) Kras ${ }^{G 12 V}$ NSCs (Figure 3F). A similar trend was observed in the Fos/1 KO shNf1 NSCs (Figure 2-figure supplement 3F, G), and the extent of MSG regulation appeared proportional to the extent of MAPK activation by individual perturbations (Figure 3A).

Altogether, these data indicated that Kras ${ }^{G 12 V}$-transduced cells, which show the highest FOSL1 expression and mesenchymal commitment, are a suitable model to functionally study the role of a MAPK-FOSL1 axis in MES GBM.

\section{Fos/1 depletion affects the chromatin accessibility of the mesenchymal transcription program and differentiation genes}

FOSL1 is a member of the AP-1 TF super family, which may be composed of a diverse set of homoand heterodimers of the individual members of the JUN, FOS, ATF, and MAF protein families. In GBM, AP-1 can act as a pioneer factor for other transcriptional regulators, such as ATF3, to coordinate response to stress in GSCs (Gargiulo et al., 2013). To test the effect of Fos/1 ablation on chromatin regulation, we performed open chromatin profiling using ATAC-seq in the p53-null Kras ${ }^{\text {G12V }}$ NSCs model (Figure 3C). This analysis revealed that Fos/1 loss strongly affects chromatin accessibility of known cis-regulatory elements such as transcription start sites (TSS) and CpG islands (CGI), as gauged by unsupervised clustering of Fos/1 wild-type and $\mathrm{KO}$ cells (Figure 4A). Consistent with a role for FOSL1/FRA-1 in maintaining chromatin accessibility at direct target genes, deletion of Fos/1 caused the selective closing of chromatin associated with the major AP-1 TFs binding sites (Figure 4B). Upon Fos/1 loss, profiling of the motifs indicated that chromatin associated with AP-1/2 TFs binding were closed and - conversely - a diverse set of general and lineage-specific TFs, including MFZ1, NRF1, RREB1, and others (Figure 4C), were opened. The genes associated with changes in chromatin accessibility upon Fos/1 loss are involved in several cell fate commitment, differentiation, and morphogenesis programs (Figure 4D, E). Next, we investigated chromatin remodeling dynamics using limma and identified 9749 regions with significant differential accessibility (absolute log2 fold-change $>1$, FDR < 0.05). Importantly, Fos/1 loss induced opening of chromatin associated with lineage-specific markers, along with closing of chromatin at the loci of genes, associated with mesenchymal GBM identity in human tumors and BTSC lines (Figure 4F-H). Taken all together, this evidence further indicates that FOSL1/FRA-1 might modulate the mesenchymal transcriptional program by regulating the chromatin accessibility of MES genes.

\section{Fosl1 deletion reduces stemness and tumor growth}

Ras activating mutations have been widely used to study gliomagenesis, in combination with other alterations as Akt mutation, loss of Ink4a/Arf or Trp53 (Friedmann-Morvinski et al., 2012; Holland et al., 2000; Koschmann et al., 2016; Muñoz et al., 2013; Uhrbom et al., 2002). Thus, we then explored the possibility that Fos/1 could modulate the tumorigenic potential of the p53-null Kras mutant cells.

Cell viability was significantly decreased in Fos/1 $\mathrm{KO}$ cell lines as compared to sgCtrl (Figure 5A). Concomitantly, we observed a significant decreased percentage of cells in S-phase (mean values: sgCtrl = 42.6\%; sgFosl1_1 = 21.6\%, Student's t test $p \leq 0.001 ;$ sgFosl1_3 $=20.4 \%$, Student's t test $\mathrm{p}=0.003$ ), an increase in percentage of cells in G2/M (mean values: sgCtrl $=11.7 \%$, sgFosl1_1 $=$ $28.4 \%$, Student's t test $p \leq 0.001$; sgFosl1_3 $=23.4 \%$, Student's t test $p=0.012$ ) (Figure $5 B$ ), and a 
A

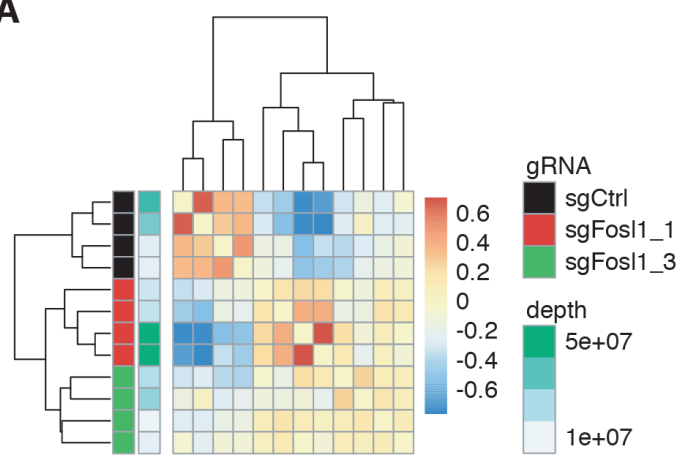

B

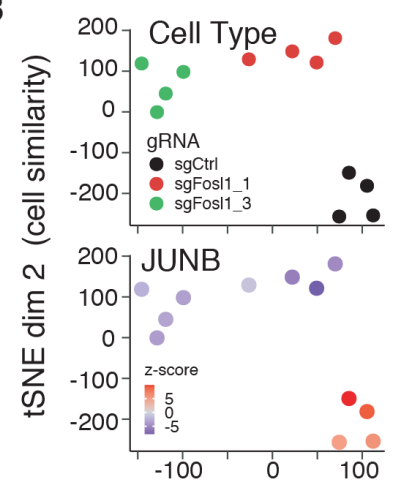

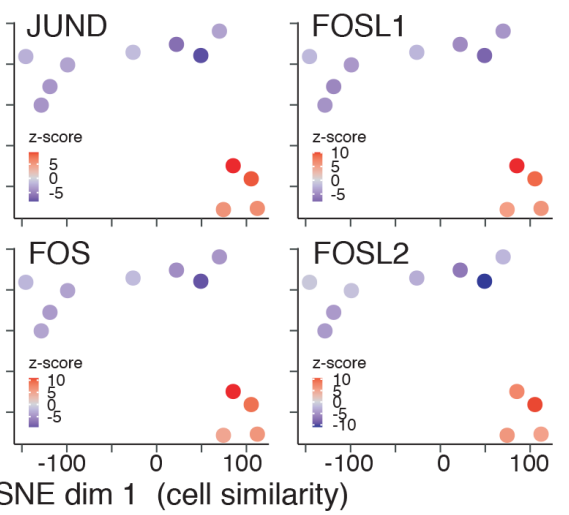

E

GO pathways TFs enriched in Fosl1-KO open regions in Fosl1-KO closed regions

anterior/posterior pattern specification appendage developmentevelopment

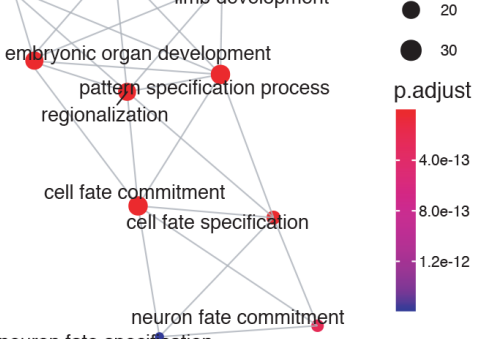

neuron fate speciffcation

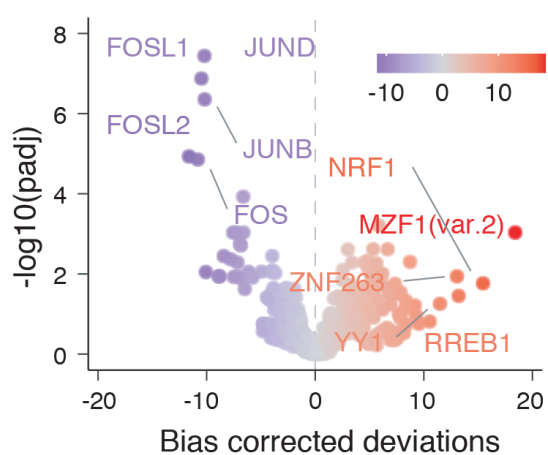

G

F

Wang_2017

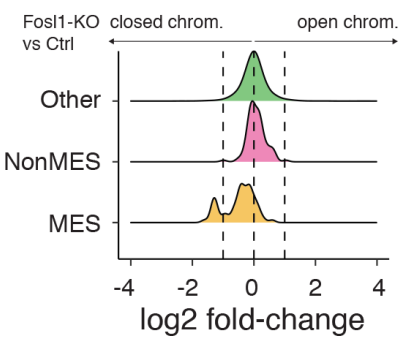

BTSCs-DE genes

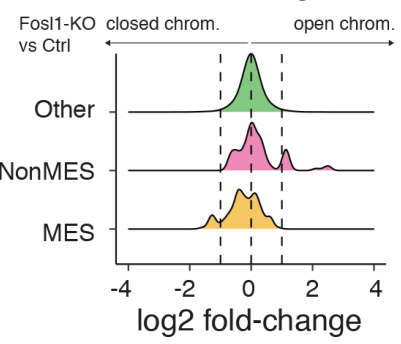

H

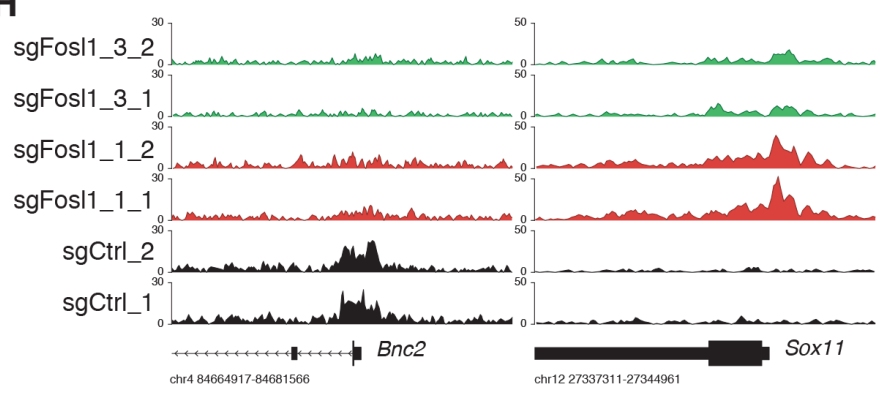

Figure 4. Fos/1 depletion affects the chromatin accessibility of mesenchymal (MES) transcription program and differentiation genes in mouse gliomainitiating cells. (A) Correlation heatmap of the ATAC-seq samples. Clustering of the Fos/1-WT (sgCtrl, $\mathrm{n}=4$ ) and Fos/1-depleted (sgFos/1_1 and sgFos/1_3, $n=8$ ) samples is based upon the bias corrected deviations in chromatin accessibility (see Materials and methods). (B) tSNE visualization of cellular similarity between Fos/1-depleted and control cells based on chromatin accessibility. Samples are color-coded according to the cell type (black, red, and green for sgCtrl, sgFosl1_1, and sgFosl1_3 cells, respectively), or by directional z-scores. (C) Volcano plot illustrating the mean difference in bias-corrected accessibility deviations between Fos/1-deficient and control cells against the FDR-corrected p-value for that difference. The top differential motifs are highlighted in violet and red, indicating decreased and increased accessibility, respectively. (D, E) Top enriched Gene Ontology (GO) biological processes pathways for the regions with decreased (D) and increased (E) chromatin accessibility upon Fos/1 loss. The nodes represent the functional categories from the respective databases, color-coded by the significance of enrichment (FDR $<0.05)$. The node size indicates the number of query genes represented among the ontology term, and the edges highlight the relative relationships among these categories. ( $F$, $G$ ) Density plots showing the distributions of the log2 fold-changes in chromatin accessibility of the indicated probes, as measured with limma by comparing Fos/1-KO versus control cells. (H) Representative ATAC-seq tracks of two technical replicates for the MES Bnc2 and non-MES Sox11 markers loci. Tracks are color-coded as in panels (A) and (B).

The online version of this article includes the following source data for figure 4:

Source data 1. Source data of Figure 4A, C-G. 
A

$\bullet$ sgCtrl $\rightarrow$ sgFosl1_1 $\rightarrow$ sgFosl1_3

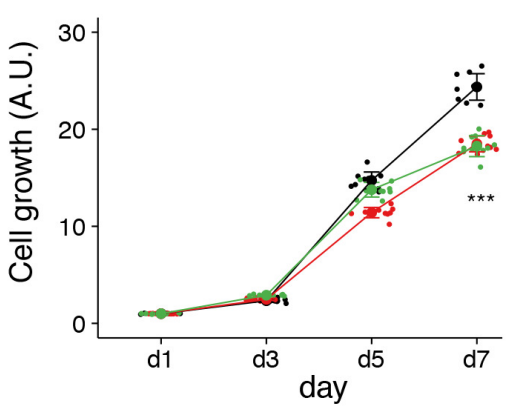

D

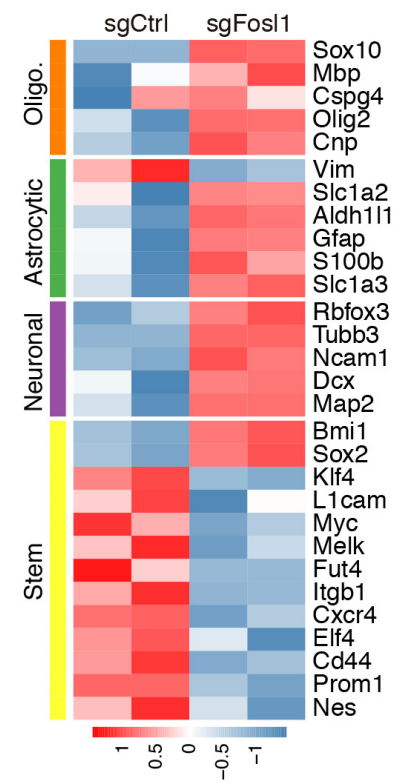

E

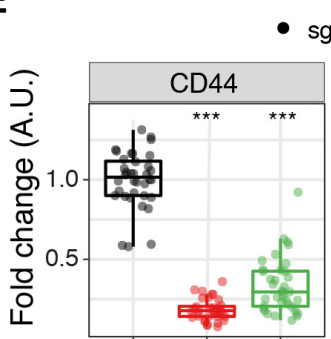

- sgCtrl • sgFosl1_1 • sgFosl1_3

G

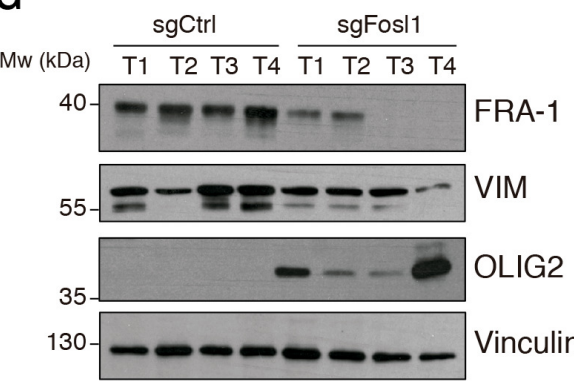

B

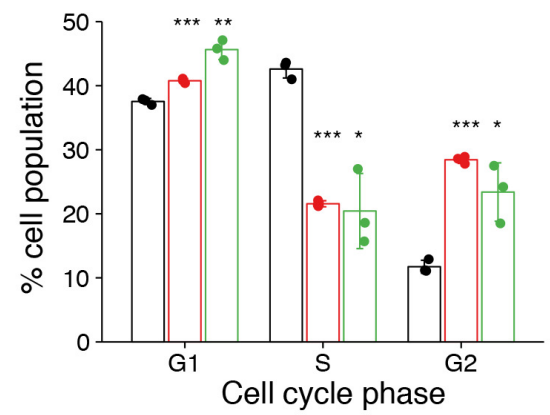

C

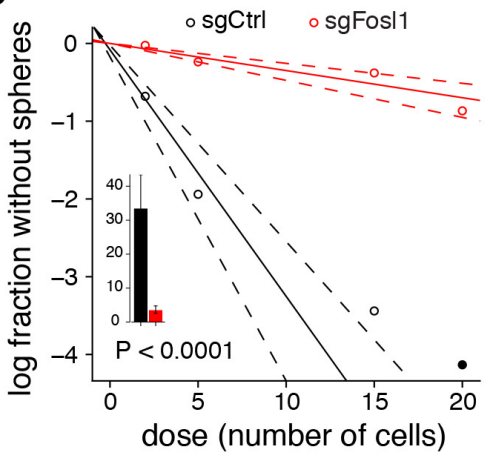

I

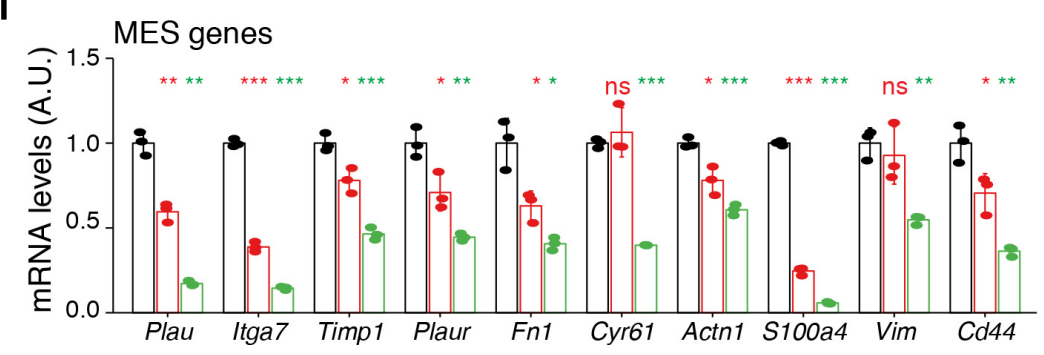

$\mathbf{F}$

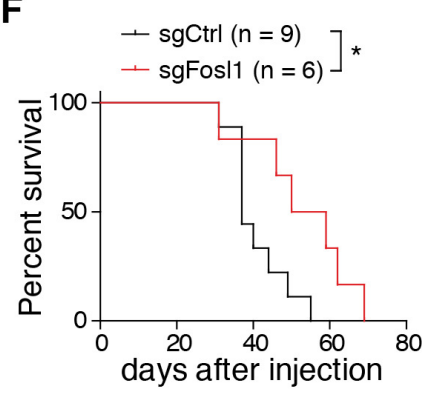

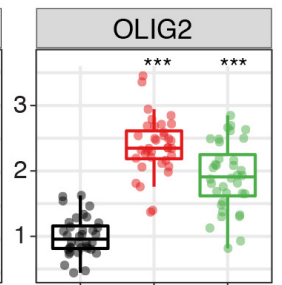

H
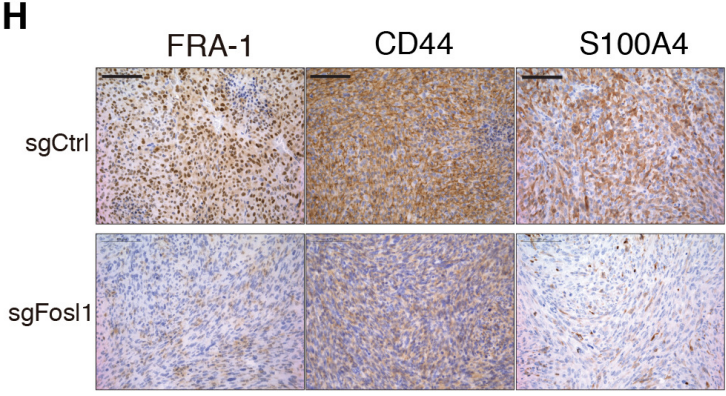

\section{J}

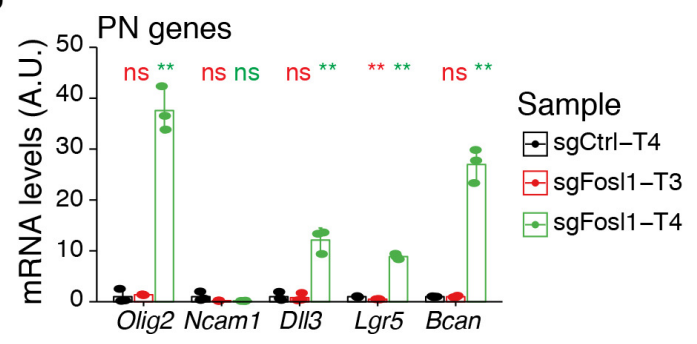

Figure 5. Fos/1 knock-out (KO) impairs cell growth and stemness in vitro and increases survival in a orthotopic glioma model. (A) Cell viability of control and Fos/1 KO p53-null Kras ${ }^{\mathrm{G} 12 \mathrm{~V}}$ neural stem cells (NSCs) measured by MTT assay; absorbance values were normalized to day 1. Data from a representative of three independent experiments are presented as mean $\pm S D(n=10$, technical replicates). Two-way ANOVA, relative to sgCtrl for both sgFos/1_1 and sgFos/1_3: ${ }^{* *} \mathrm{p} \leq 0.001$. (B) Quantification of cell cycle populations of control and Fos/1 KO p53-null Kras ${ }^{\mathrm{G} 12 V}$ NSCs by flow cytometry analysis of PI staining. Data from a representative of two independent experiments are presented as mean $\pm S D(n=3$, technical replicates).

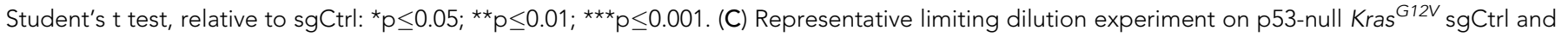
sgFos/1_1 NSCs, calculated with extreme limiting dilution assay (ELDA) analysis; bar plot inlet shows the estimated stem cell frequency with the confidence interval; chi-square $p<0.0001$. (D) Heatmap of expression of stem cell (yellow) and lineage-specific (neuronal - purple, astrocytic - green, and oligodendrocytic - orange) genes, comparing sgCtrl and sgFos/1_1 p53-null Kras ${ }^{G 12 V}$ NSCs. Two biological replicates are shown. (E) Quantification of pixel area (fold-change relative to sgCtrl) of CD44, GFAP, and OLIG2 relative to DAPI pixel area per field of view in control and Fos/1 KO p53-null Kras $^{G 12 V}$ NSCs. Data from a representative of two independent experiments; Student's t test, relative to sgCtrl: ${ }^{\star \star *} p \leq 0.001$. (F) Kaplan-Meier survival Figure 5 continued on next page 
Figure 5 continued

curves of nu/nu mice injected with p53-null Kras ${ }^{G 12 V} \operatorname{sgCtrl}(n=9)$ and sgFos/1_1 $(n=6)$ NSCs. Log-rank p=0.0263. (G) Western blot analysis using the indicated antibodies of four sgCtrl and four sgFos/1_1 tumors (showing low or no detectable expression of FRA-1); vinculin was used as loading control. (H) Representative images of IHCs using the indicated antibodies. Scale bars represent $100 \mu \mathrm{m}$. (I) mRNA expression of MES genes in the samples sgCtrl-T4 (higher FRA-1 expression) and sgFosl1_1-T3 and -T4 (no detectable FRA-1 expression). (J) mRNA expression of PN genes in samples as in $(H)$. Data from a representative of two experiments are presented as mean $\pm S D(n=3$, technical replicates), normalized to Gapdh expression. Student's t test for sgFosl1_1 tumors, relative to sgCtrl-T4: ns = not significant, ${ }^{\star} p \leq 0.05,{ }^{* \star} p \leq 0.01,{ }^{\star \star *} p \leq 0.001$.

The online version of this article includes the following source data and figure supplement(s) for figure 5 :

Source data 1. Source data of Figure 5G.

Source data 2. Source data of Figure $5 A-C, E, F, I, J$.

Figure supplement 1. Fos/1 loss is associated with the reduction of proliferative genes and increase in differentiation genes.

reduction of the expression of cell cycle regulator genes (Ccnb1, Ccnd1, Ccne1, and Cdk1, among others) (Figure 5-figure supplement 1A).

Another aspect that contributes to GBM aggressiveness is its heterogeneity, attributable in part to the presence of GSCs. By using limiting dilution assays, we found that Fos/1 is required for the maintenance of stem cell activity, with a stem cell frequency estimate of sgFosl1_1 $=28.6$ compared to $\mathrm{sgCtrl}=3$ (chi-square $\mathrm{p}<2.2 \mathrm{e}-16$ ) (Figure $5 \mathrm{C}$ ). Moreover, RNA-seq analysis showed that sgFosl1_1 cells downregulated the expression of stem genes (Elf4, Klf4, Itgb1, Nes, Sall4, L1cam, Melk, Cd44, Myc, Fut4, Cxcr4, Prom1) while upregulating the expression of lineage-specific genes: neuronal (Map2, Ncam1, Tubb3, Slc1a2, Rbfox3, Dcx), astrocytic (Aldh1/1, Gfap, S100b, Slc1a3), and oligodendrocytic (Olig2, Sox10, Cnp, Mbp, Cspg4) (Figure 5D). The different expression of some of the stem/differentiation markers was confirmed also by immunofluorescence analysis. While Fos/1 $\mathrm{KO}$ cells presented low expression of the stem cell marker CD44, differentiation markers as GFAP and OLIG2 were significantly higher when compared to sgCtrl cells (Figure 5E and Figure 5-figure supplement 1B).

We then sought to test whether (i) p53-null Kras ${ }^{G 12 V}$ NSCs were tumorigenic and (ii) Fos/1 played any role in their tumorigenic potential. Intracranial injections of p53-null Kras ${ }^{G 12 V}$ NSCs in nu/nu mice led to the development of high-grade tumors with a median survival of 37 days in control cells $(n=9)$. In contrast, sgFos/1_1-injected mice $(n=6)$ had a significant increase in median survival (54.5 days, log-rank $\mathrm{p}=0.0263$ ) (Figure 5F). Consistent with our in vitro experiments (Figure 3D-F), Fos/1depleted tumors failed to support mesenchymal program (Figure 5G-I). Western blot, immunohistochemical, and QPCR analysis show the reduction of MES markers (VIM, CD44, and S100A4) and the expression of the PN marker OLIG2 to depend on Fos/1 expression (Figure 5G-J).

Overall, our data in p53-null Kras mutant NSCs support the conclusion that, besides controlling cell proliferation, Fos/1 plays a critical role in the maintenance of the stem cell activity and tumorigenicity.

\section{Fos/1 amplifies mesenchymal gene expression}

To further assess the role of Fos/1 as a key player in the control of the MGS, we used a mouse model of inducible Fos/1 overexpression containing the alleles Kras ${ }^{\text {LSLG12V; }}$;rp53 ${ }^{\text {lox; }}$; ROSA26 $6^{\text {LSLrTA-IRES- }}$ EGFP; Col1a $1^{\text {TetO-Fosl1 }}$ (here referred to as Fos $11^{\text {tetON }}$ ). Similar to the loss-of-function approach here used, this allelic combination allows the expression of $\mathrm{Kras}^{\mathrm{G} 12 \mathrm{~V}}$ and deletion of $\mathrm{p} 53$ after Cre recombination. Moreover, the expression of the reverse tetracycline transactivator (rtTA) allows, upon induction with doxycycline (Dox), the ectopic expression of Fos/1 (Flag tagged), under the control of the Col1a1 locus and a tetracycline-responsive element (TRE or Tet-O) (Belteki, 2005; Hasenfuss et al., 2014).

NSCs derived from Fos $11^{W T}$ and Fos $/ 1^{\text {tetON }}$ mice were infected in vitro with a lentiviral vector expressing the Cre recombinase and efficient infection was confirmed by fluorescence microscopy as the cells expressing the rtTA should express GFP (data not shown). FRA-1 overexpression, as well as Flag-tag expression, was then tested by western blot after $72 \mathrm{hr}$ of Dox induction (Figure 6A). When Fos $11^{\text {tetON }}$ NSCs were analyzed by qRT-PCR for the expression of MES/PN markers, a significant upregulation of most MES genes and downregulation of PN genes was found in the cells overexpressing Fos/1 (Figure 6B, C), thereby complementing our findings in Fos/1 KO cells. 
A

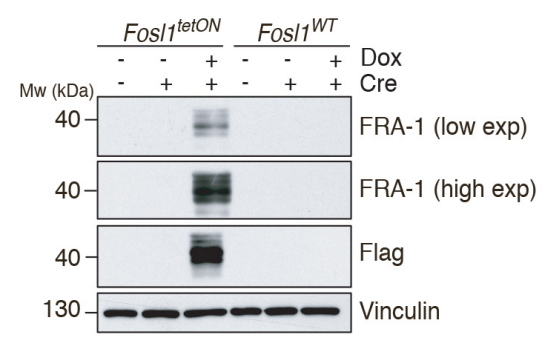

D

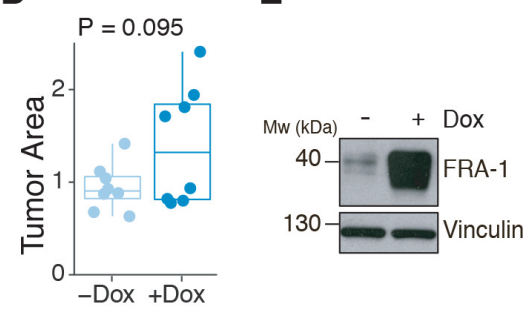

H

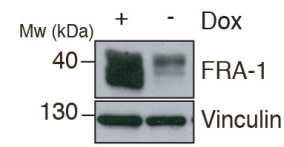

B

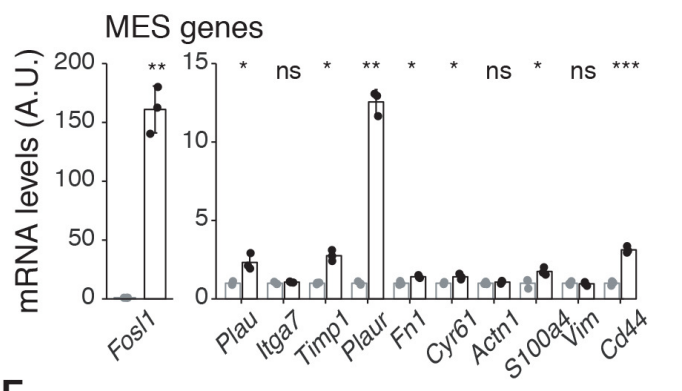

$\mathrm{F}$

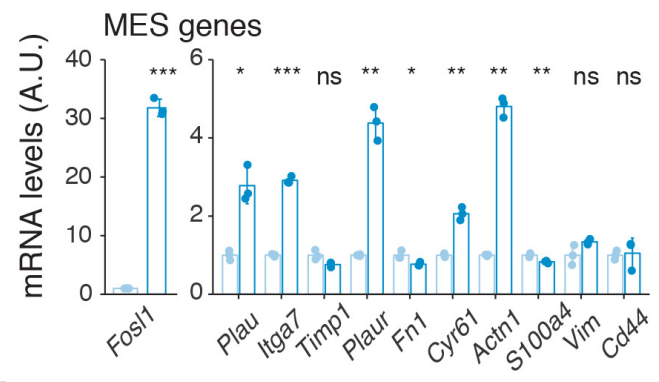

|

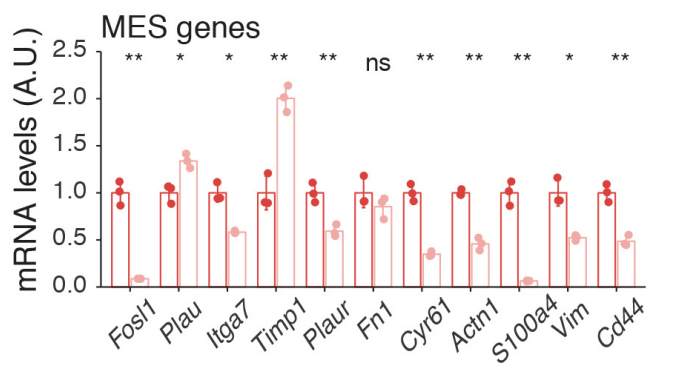

C

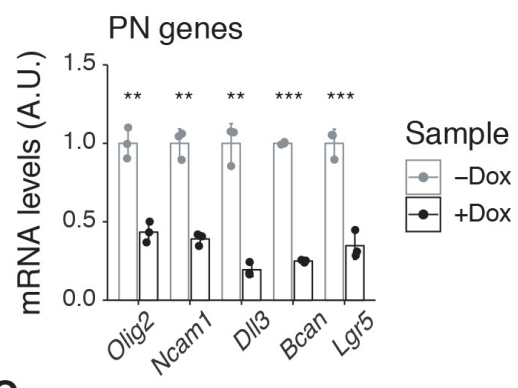

G

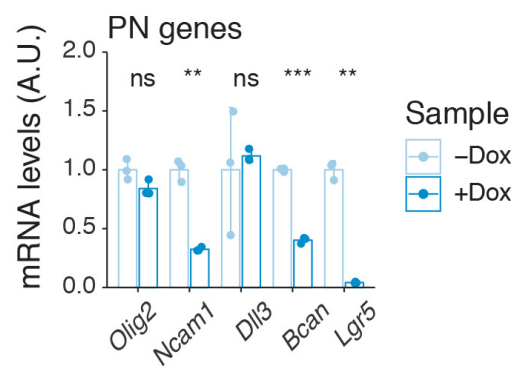

J

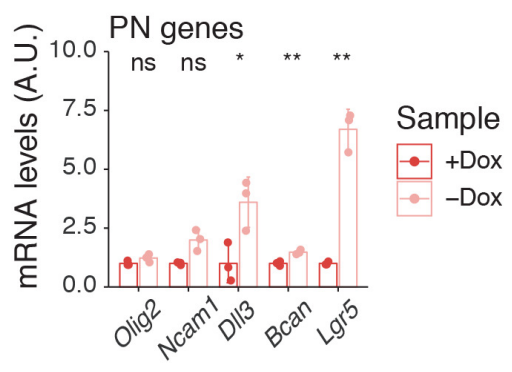

Figure 6. Fos/1 overexpression upregulates the MES gene signature (MGS) and induces larger tumors in vivo. (A) Western blot analysis of FRA-1 and Flag expression on Fos $11^{\text {tetON }}$ and Fos $11^{W T}$ neural stem cells (NSCs) derived from Kras LSLG12V; Trp53 ${ }^{\text {lox }}$; ROSA26 LSLrtTA-IRES-EGFP. Col1a $1^{\text {TetO-Fos } 11}$ mice upon in vitro infection with Cre and induction of Fos/1 overexpression with $1 \mu \mathrm{g} / \mathrm{mL}$ doxycycline (Dox) for $72 \mathrm{hr}$; vinculin was used as loading control. (B) mRNA expression of Fos/1 and mesenchymal (MES) genes in Fos $11^{\text {tetON }}$ p53-null Kras ${ }^{\text {G12V }}$ cells upon $72 \mathrm{hr}$ induction with $1 \mu \mathrm{g} / \mathrm{mL}$ Dox. (C) mRNA expression of PN genes in Fos $/ 1^{\text {tetON }}$ p53-null Kras ${ }^{G 12 V}$ cells upon $72 \mathrm{hr}$ induction with $1 \mu \mathrm{g} / \mathrm{mL}$ Dox. (D) Quantification of tumor area ( $\mu \mathrm{m}^{2}$ ) of - Dox and +Dox tumors $(n=8 / 8)$. For each mouse, the brain section on the hematoxylin and eosin (H\&E) slide with a larger tumor was considered and quantified using the ZEN software (Zeiss). (E) Western blot detection of FRA-1 expression in tumorspheres derived from a control (-Dox) tumor. Tumorspheres were isolated and kept without Dox until first passage, when $1 \mu \mathrm{g} / \mathrm{mL}$ Dox was added and kept for 19 days (+Dox in vitro). (F) mRNA expression of Fos/1 and MES genes in tumorspheres in the absence or presence of Dox for 19 days. (G) mRNA expression of PN genes in tumorspheres in the absence or presence of Dox for 19 days. (H) Western blot detection of FRA-1 expression in tumorspheres derived from a Fos/1 overexpressing (+Dox) tumor. Tumorspheres were isolated and kept with $1 \mu \mathrm{g} / \mathrm{mL}$ Dox until first passage, when Dox was removed for 19 days (-Dox in vitro). (I) mRNA expression of Fos/1 and MES genes in tumorspheres in the presence or absence of Dox for 19 days. (J) mRNA expression of PN genes in tumorspheres in the presence or absence of Dox for 19 days. qRT-PCR data from a representative of two experiments are presented as mean \pm SD $(n=3$, technical replicates), normalized to Gapdh expression. Student's t test, relative to the respective control ( - Dox in B, C, F, and G; +Dox in I and J): ns = not significant, ${ }^{*} \mathrm{p} \leq 0.05,{ }^{* *} \mathrm{p} \leq 0.01,{ }^{\star * *} \mathrm{p} \leq 0.001$.

The online version of this article includes the following source data and figure supplement(s) for figure 6:

Source data 1. Source data of Figure 6A.

Source data 2. Source data of Figure 6E.

Source data 3. Source data of Figure $6 \mathrm{H}$.

Source data 4. Source data of Figure 6B-D, F, G, I,J.

Figure supplement 1. Characterization of Fos/1 overexpressing mouse tumors.

Figure supplement 1-source data 1. Source data of Figure 6-figure supplement 1A. 
To investigate if the MES phenotype induced with Fos/1 overexpression would have any effect in vivo, p53-null Kras ${ }^{G 12 V}$ Fos/1 ${ }^{\text {tetON }}$ NSCs were intracranially injected into syngeneic C57BL/6J wildtype mice. Injected mice were randomized and subjected to Dox diet (food pellets and drinking water) or kept as controls with regular food and drinking water with $1 \%$ sucrose. Fos 11 overexpressing mice (+Dox) developed larger tumors that were more infiltrative and aggressive than controls (Dox), which mostly grew as superficial tumor masses instead (Figure 6D). This phenotype appears to be independent of tumor cells proliferation as gauged by Ki-67 staining and does not affect overall survival (Figure 6-figure supplement 1A, B).

Tumorspheres were derived from -Dox and +Dox tumor-bearing mice, and Fos/1 expression was manipulated in vitro through addition or withdrawal of Dox from the culture medium. In the case of tumorspheres derived from a -Dox tumor, when Dox was added for 19 days, high levels of FRA-1 expression were detected by western blot (Figure 6E). At the mRNA level, Dox treatment also greatly increased Fos/1 expression, as well as some of the MES genes (Figure 6F), while the expression of PN genes was downregulated (Figure 6G). Conversely, when Dox was removed from +Doxderived tumorspheres for 19 days, the expression of FRA-1 decreased (Figure $6 \mathbf{H}$, I), along with the expression of MES genes (Figure 6I), while PN genes were upregulated (Figure 6J). These results

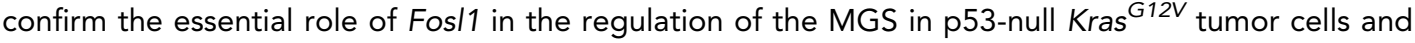
the plasticity between the PN and MES subtypes.

\section{FOSL1 controls growth, stemness, and mesenchymal gene expression in patient-derived BTSCs}

To prove the relevance of our findings in the context of human tumors, we analyzed BTSC lines characterized as non-MES (h676, h543, and BTSC 268) or MES (BTSC 349, BTSC 380, and BTSC 233) (this study and Ozawa et al., 2014). By western blot, we found that consistent with what was observed either in human BTSCs (Figure 1D) or mouse NSCs (Figure 3A), MES cell lines expressed high levels of FRA-1 and activation of the MEK/ERK pathway (Figure 7A).

To study the role of FOSL1 in the context of human BTSCs, its expression was modulated in the MES BTSC 380 using two Dox-inducible shRNAs (shFOSL1_3 and shFOSL1_10). We confirmed by western blot FRA-1 downregulation after 3 and 7 days of Dox treatment (Figure 7B). In line to what was observed in mouse glioma-initiating cells, FOSL1 silencing in MES BTSC 380 resulted in reduced cell growth (Figure $7 C$ ) with a significant reduction of the percentage of BrdU positive cells compared to Dox-untreated cells (Figure 7D). Moreover, FOSL1 silencing decreased the sphere-forming capacity of MES BTSC 380 with an estimated stem cell frequency of shGFP -Dox $=3.5$, shGFP +Dox $=3.4$, chi-square $\mathrm{p}=0.8457$; shFOSL1_3 - Dox $=4.3$, shFOSL1_3 +Dox = 7.6, chi-square $\mathrm{p}=0.0002195 ;$ shFOSL1_10 -Dox $=5.4$, shFOSL1_10 +Dox $=11.1$, chi-square $\mathrm{p}=5.918 \mathrm{e}-06$ (Figure 7E). Comparable results were also obtained in the MES BTSC 349 cells (Figure 7-figure supplement 1A-D). In line with our mouse experiments, FOSL1 silencing resulted in the significant downregulation of the MES genes (Figure 7-figure supplement 1E, left panel), whereas proneural gene expression was unchanged (Figure 7-figure supplement 1E, right panel). Of note, FOSL1 silencing affected BTSCs fitness also when propagated in differentiation conditions (Figure 7-figure supplement $1 F, G)$.

Similar to what was observed in mouse tumors (Figure 6-figure supplement 1B), FOSL1 overexpression in two non-MES lines (h543 and h676) did not lead to changes in their proliferation capacity (Figure 7-figure supplement 1H, I). Most importantly, FOSL1 silencing in these non-MES lines had no impact on cell growth (Figure 7-figure supplement $1 \mathrm{~J}, K)$, underscoring a mesenchymal context-dependent role for FOSL1 in glioma cells.

We then tested whether FOSL1/FRA-1 modulates the MGS via direct target regulation. To this end, we first identified high-confidence FOSL1/FRA-1 binding sites in chromatin immunoprecipitation-seq (ChIP-seq) previously generated in the KRAS mutant HCT116 colorectal cancer cell line (see Materials and methods), and then we determined the counts per million reads (CPM) of the enhancer histone mark H3K27Ac in a set of MES $(n=10)$ and non-MES BTSCs $(n=10)$ (Mack et al., 2019), selected based on the highest and lowest FOSL1 expression, respectively. PCA showed a marked separation of the two groups of BTSCs (Figure 7F). Differential enrichment analysis by DESeq2 revealed 11748 regions statistically significant (FDR < 0.005) for H3K27Ac at FOSL1/FRA-1 binding sites in either MES or non-MES BTSCs (Figure 7G). Next, we compared H3K27Ac distribution over FOSL1/FRA-1 binding sites to that of the non-MES MR OLIG2. This analysis showed that 
A

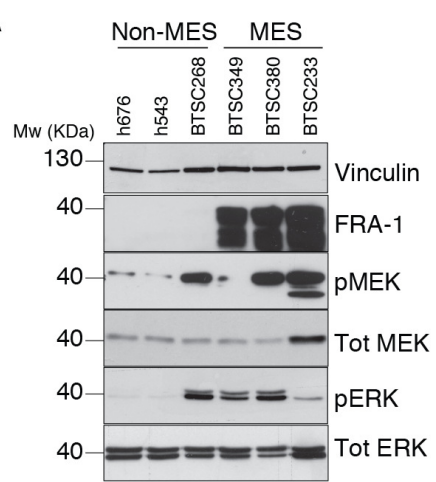

D

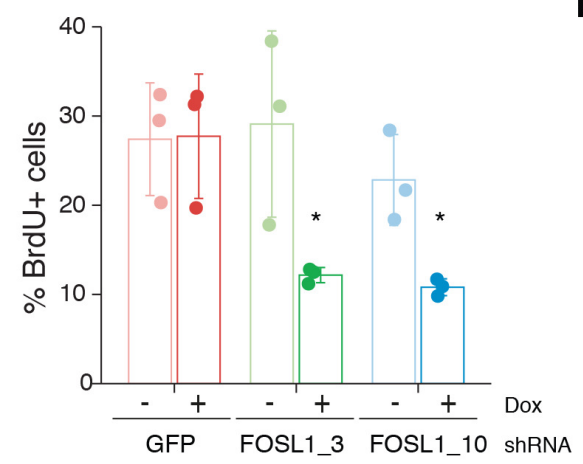

F

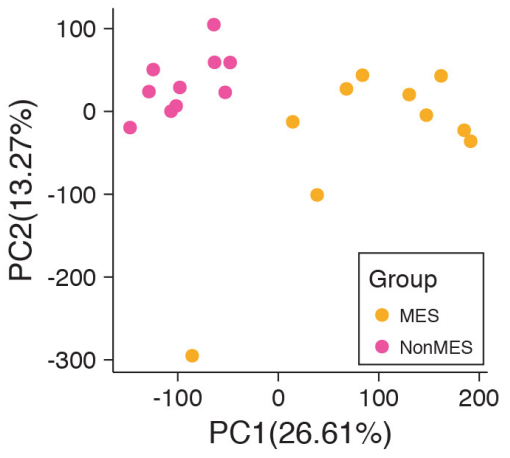

G
B

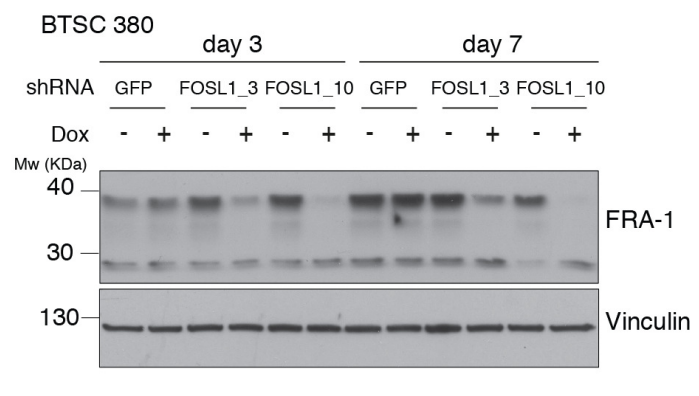

C

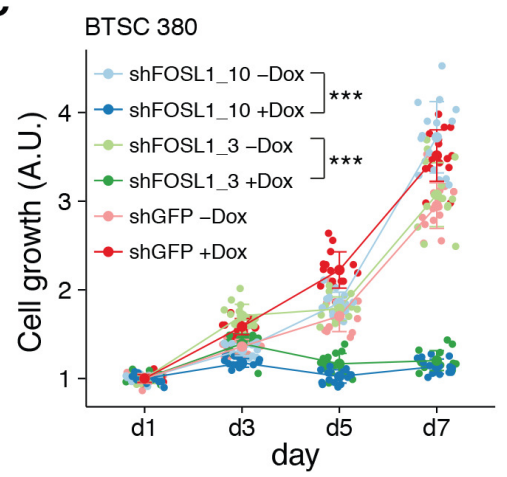

E
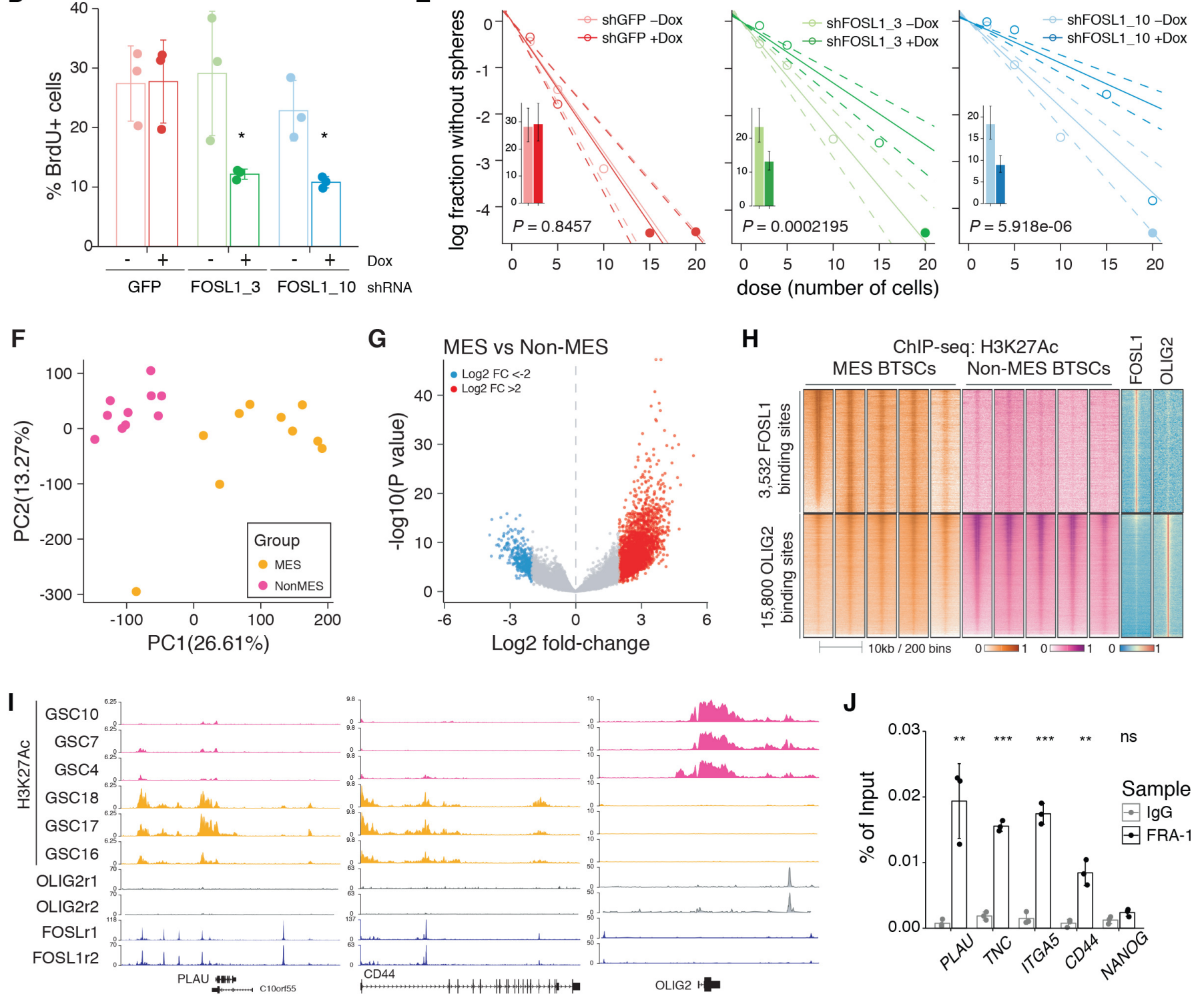

Figure 7. FOSL1 contributes to mesenchymal (MES) genes activation, cell growth, and stemness in MES brain tumor stem cells (BTSCs). (A) Western blot analysis using the specified antibodies of human BTSC lines, characterized as non-MES (left) and MES (right). (B) Western blot detection of FRA-1 in MES BTSC 380 upon transduction with inducible shRNAs targeting GFP (control) and FOSL1, analyzed after 3 and 7 days of doxycycline (Dox) treatment; vinculin was used as loading control. (C) Cell growth of BTSC 380 shGFP and shFOSL1, in the absence or presence of Dox, measured by Figure 7 continued on next page 
Figure 7 continued

MTT assay; absorbance values were normalized to day 1. Data from a representative of three independent experiments are presented as mean \pm SD ( $n=15$, technical replicates). Two-way ANOVA, -Dox vs. +Dox: ${ }^{\star \star \star} p \leq 0.001$. (D) BrdU of BTSC 380 shGFP and shFOSL1, in the absence or presence of Dox, analyzed by flow cytometry. Data from a representative of two independent experiments are presented as mean $\pm S D$ ( $n=3$, technical replicates). Student's t test, relative to the respective control (-Dox): ${ }^{*} p \leq 0.05$. (E) Representative limiting dilution analysis on BTSC380 for shGFP and shFOSL1, in the presence or absence of Dox, calculated with extreme limiting dilution assay (ELDA) analysis; bar plot inlets show the estimated stem cell frequency with the confidence interval; chi-square $p$-values are indicated. (F) Principal component analysis of H3K27Ac signal over FOSL1/FRA-1 binding sites, calculated using MACS on ENCODE samples (see Materials and methods), in non-MES ( $n=10$ ) and MES BTSC ( $n=10)$ (from Mack et al., 2019). (G) Volcano plot illustrating the log2 fold-change differences in H3K27Ac signal between non-MES and MES BTSCs against the p-value for that difference. Blue and red probes represent statistically significant differences (FDR < 0.005) in H3K27Ac signal between non-MES and MES BTSCs. (H) Heatmap of ChIP-seq enrichment of FOSL1/FRA-1 or OLIG2 binding sites for the indicated profiles. (I) View of the PLAU, CD44, and OLIG2 loci of selected profiles. (J) Representative ChIP experiment in BTSC 349 cells. The panel shows FRA-1 binding to the promoter of a subset of MES targets ( $\mathrm{n}=3$, technical replicates) expressed as a percentage of the initial DNA amount in the immune-precipitated fraction. NANOG gene was used as a negative control. Student's $t$ test, relative to lgG: $n s=$ not significant, ${ }^{* \star} p \leq 0.01,{ }^{* \star *} p \leq 0.001$.

The online version of this article includes the following source data and figure supplement(s) for figure 7 :

Source data 1. Source data of Figure 7A.

Source data 2. Source data of Figure 7B.

Source data 3. Source data of Figure 7C-G, J.

Figure supplement 1. Further characterization of FOSL1 role in human brain tumor stem cells (BTSCs).

Figure supplement 1-source data 1. Source data of Figure 7-figure supplement 1A.

Figure supplement 1-source data 2. Source data of Figure 7-figure supplement $1 \mathrm{H}$.

Figure supplement 1-source data 3. Source data of Figure 7-figure supplement $1 \mathrm{~J}$.

Figure supplement 1-source data 4. Source data of Figure 7-figure supplement 1B-E, G, I, K.

FOSL1/FRA-1 binding sites were systematically decorated with H3K27Ac in MES BTSCs, while the inverse trend was observed at OLIG2 binding sites (Figure $7 \mathrm{H}, \mathrm{I}$ ). Validation by ChIP-qPCR in an independent MES BTSC line (BTSC 349) confirmed FRA-1 direct binding at promoters of some MES genes including PLAU, TNC, ITGA5, and CD44 in GBM cells (Figure 7J).

Altogether, our data support that FOSL1/FRA-1 regulates MES gene expression and aggressiveness in human gliomas via direct transcriptional regulation, downstream of the NF1-MAPKFOSL1 signaling.

\section{Discussion}

The most broadly accepted transcriptional classification of GBM was originally based on gene expression profiles of bulk tumors (Verhaak et al., 2010), which did not discriminate the contribution of tumor cells and TME to the transcriptional signatures. It is now becoming evident that both cell-intrinsic and -extrinsic cues can contribute to the specification of the MES subtype (Bhat et al., 2013; Hara et al., 2021; Neftel et al., 2019; Schmitt et al., 2021; Wang et al., 2017). Bhat and colleagues had shown that while some of the MES GBMs maintained the mesenchymal characteristics when expanded in vitro as BTSCs, some others lost the MGS after few passages while exhibiting a higher non-MGSs (Bhat et al., 2013). These data, together with the evidence that xenografts into immunocompromised mice of BTSCs derived from MES GBMs were also unable to fully restore the MES phenotype (Bhat et al., 2013), suggested that the presence of an intact TME potentially contributed to the maintenance of a MGS. In support of this, Schmitt and colleagues have recently shown that innate immune cells divert GBM cells to a proneural-to-mesenchymal transition (PN-toMES) that also contributes to therapeutic resistance (Schmitt et al., 2021).

The transcriptional GBM subtypes were lately redefined based on the expression of glioma-intrinsic genes, thus excluding the genes expressed by cells of the TME (Richards et al., 2021; Wang et al., 2017). Our MRA on the BTSCs points to the AP-1 family member FOSL1 as one pioneer TF contributing to the cell-intrinsic MGS. Previous tumor bulk analysis identified a related AP-1 family member FOSL2, together with CEBPB, STAT3, and TAZ, as important regulators of the MES GBM subtype (Bhat et al., 2011; Carro et al., 2010). While FOSL1 was also listed as a putative MES MR (Carro et al., 2010), its function and mechanism of action have not been further characterized since then. Our experimental data show that FOSL1 is a key regulator of GBM subtype plasticity and MES transition, and define the molecular mechanism through which FOSL1 is regulated. While here 
we have focused on the TFs contributing to MES specifications, previous studies had highlighted the role of other TFs, some of which were also identified in our MRA, such as OLIG2, SALL2, and ASCL1, as important molecules for non-MES GBM cells (Suvà et al., 2014). Moreover, using a similar MRA, $\mathrm{Wu}$ and colleagues have recently described also SOX10 as another TF that contributes to the identity of non-MES GBM cells. Strikingly, loss of SOX10 resulted in MES transition associated with changes in chromatin accessibility in regions that are specifically enriched for FRA-1 binding motifs (Wu et al., 2020). Lastly, using an unbiased CRISPR/Cas9 genome-wide screening, Richards and colleagues had shown that few of the top TFs identified here, such as FOSL1, OLIG2, and ASCL1, are genes essential specifically either for MES GSCs (FOSL1) or for non-MES GSCs (OLIG2 and ASCL1) (Richards et al., 2021). This evidence further strengthen the relevance of the MRA that we have performed in the identification of important regulators of GBM subtype-specific cell biology.

Although consistently defined, GBM subtypes do not represent static entities. The plasticity between subtypes happens at several levels. Besides the referred MES-to-PN change in cultured GSCs compared to the parental tumor (Bhat et al., 2013), a PN-to-MES shift often occurs upon treatment and recurrence. Several independent studies comparing matched pairs of primary and recurrent tumors demonstrated a tendency to shift towards a MES phenotype, associated with a worse patient survival, likely as a result of treatment-induced changes in the tumor and/or the microenvironment (Phillips et al., 2006; Varn et al., 2021; Wang et al., 2016; Wang et al., 2017). Moreover, distinct subtypes/cellular states can coexist within the same tumor (Neftel et al., 2019; Patel et al., 2014; Richards et al., 2021; Sottoriva et al., 2013; Varn et al., 2021; Wang et al., 2019) and targeting these multiple cellular components could result in more effective treatments (Wang et al., 2019).

PN-to-MES transition is often considered an EMT-like phenomenon, associated with tumor progression (Fedele et al., 2019). The role of FOSL1 in EMT has been studied in other tumor types. In breast cancer cells, FOSL1 expression correlates with mesenchymal features and drives cancer stem cells (Tam et al., 2013) and the regulation of EMT seems to happen through the direct binding of FRA-1 to promoters of EMT genes such as Tgfb1, Zeb1, and Zeb2 (Bakiri et al., 2015). In colorectal cancer cells, FOSL1 was also shown to promote cancer aggressiveness through EMT by direct transcription regulation of EMT-related genes (Diesch et al., 2014; Liu et al., 2015).

It is well established that NF1 inactivation is a major genetic event associated with the MES subtype (Verhaak et al., 2010; Wang et al., 2017). However, this is probably a late event in MES gliomagenesis as all tumors possibly arise from a PN precursor and just later in disease progression acquire NF1 alterations that are directly associated with a transition to a MES subtype (Ozawa et al., 2014). Moreover, NF1 deficiency has been linked to macrophage/microglia infiltration in the MES subtype (Wang et al., 2017). The fact that the enriched macrophage/microglia microenvironment is also able to modulate a MES phenotype suggests that there might be a twoway interaction between tumor cells and TME. The mechanisms of NF1-regulated chemotaxis and whether this relationship between the TME and MGS in GBM is causal remain elusive.

Here, we provide evidence that manipulation of NF1 expression levels in patient-derived BTSCs has a direct consequence on the tumor-intrinsic MGS activation and that such activation can at least in part be mediated by the modulation of FOSL1. Among the previously validated MRs, only CEBPB appears also to be finely tuned by NF1 inactivation. This suggests that among the TFs previously characterized (such as FOSL2, STAT3, BHLHB2, and RUNX1), FOSL1 and CEBPB might play a dominant role in the NF1-mediated MES transition that occurs in a glioma cell-intrinsic manner. However, whether FOSL1 contributes also to the cross-talk between the TME and the cell-intrinsic MGS still has to be established.

Furthermore, we show that FOSL1 is a crucial player in glioma pathogenesis, particularly in a MAPK-driven MES GBM context (Figure 8). Most likely, the existence of a NF1-MAPK-FOSL1 axis goes beyond GBM pathogenesis since FOSL1 appears to be upregulated in concomitance with NF1 mutations in multiple tumor types (Figure 8-figure supplement 1). Our findings broaden its previously described role in KRAS-driven epithelial tumors, such as lung and pancreatic ductal adenocarcinoma (Vallejo et al., 2017). NF1 inactivation results in Ras activation, which stimulates downstream pathways as MAPK and PI3K/Akt/mTOR. RAS/MEK/ERK signaling in turn regulates FRA-1 protein stability (Casalino et al., 2003; Verde et al., 2007). FOSL1 mRNA expression is then most likely induced by binding of the SRF/Elk1 complex to the serum-responsive element (SRE) on FOSL1 promoter (Esnault et al., 2017). At the same time, FRA-1 can then directly bind to its own promoter to 


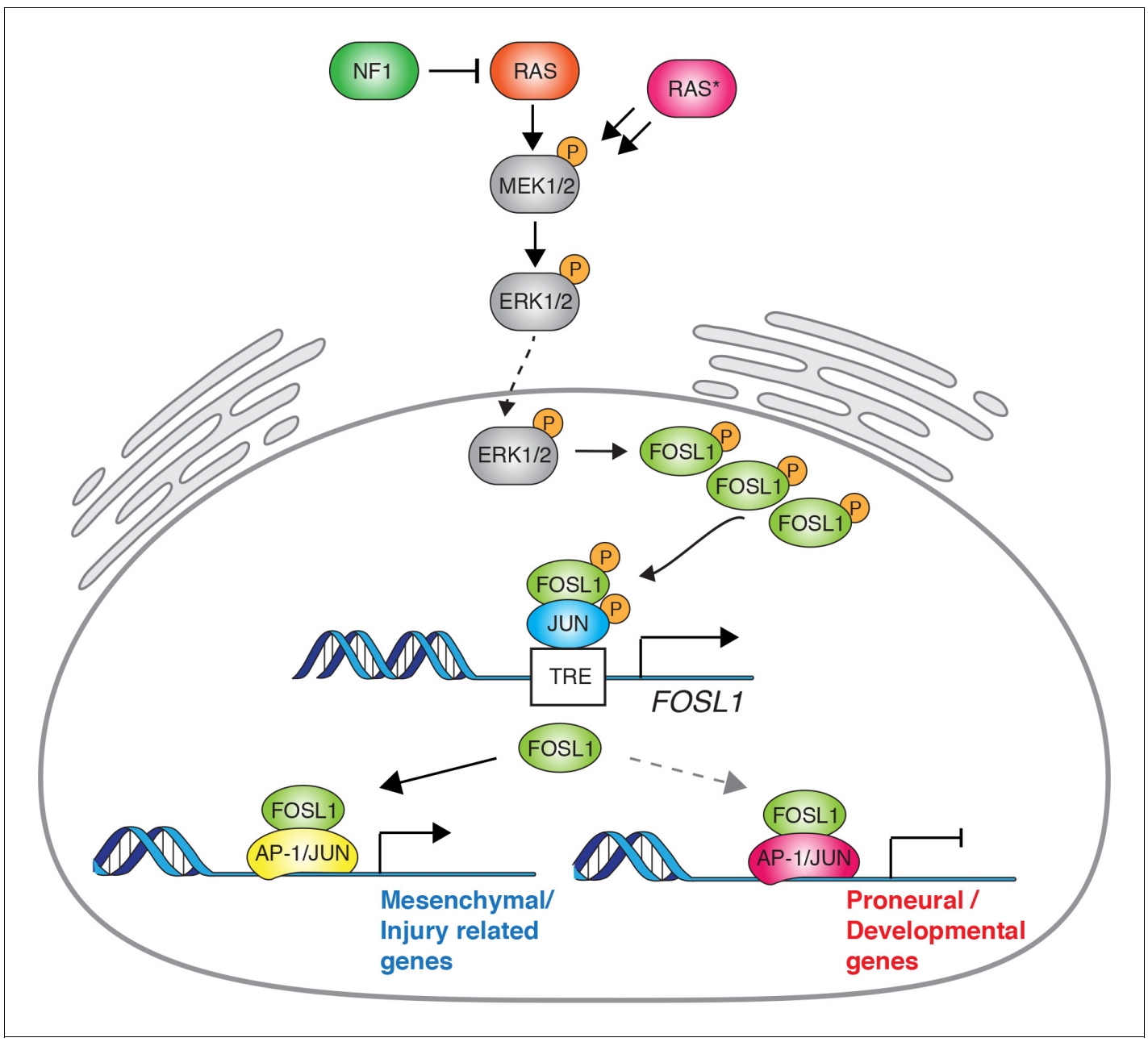

Figure 8. Schematic model of NF1-MAPK-FOSL1 axis in mesenchymal (MES) gliomas. NF1 alterations or RAS mutations lead to the activation of the MAPK signaling that in turn increases FOSL1 expression both at the mRNA and protein levels. FOSL1 then activates the expression of the MES gene signature and possibly inhibits the non-MES gene signature. The scheme integrates data presented in this work as well as previously published literature on the regulation of FOSL1 expression by MAPK activation.

The online version of this article includes the following figure supplement(s) for figure 8:

Figure supplement 1. NF1 mutations are associated with higher FOSL1 expression in multiple cancer types.

activate its own expression (Diesch et al., 2014; Lau et al., 2016) and those of MES genes. This further generates a feedback loop that induces MGS, increases proliferation and stemness, sustaining tumor growth. FRA-1 requires, for its transcriptional activity, heterodimerization with the AP-1 TFs JUN, JUNB, or JUND (Eferl and Wagner, 2003). Which of the JUN family members participate in the MES gene regulation and whether FOSL1/FRA-1 activates MES gene expression and simultaneously represses non-MES genes requires further investigation. Of note, pancancer analysis of anatomically distinct solid tumors suggested that c-JUN/JUNB and FOSL1/2 are bona fide canonical AP-1 TF configurations in mesenchymal states of lung, kidney, and stomach cancers (Serresi et al., 2021). Intriguingly, in support of a direct role in the repression of non-MES genes in GBM cells, it has been hypothesized, though not formally demonstrated, that FOSL1/FRA-1 could act as a transcriptional repressor of a core set of neurodevelopmental TFs, including OLIG2 and SALL2 (Fiscon et al., 2018).

In conclusion, FOSL1/FRA-1 is a key regulator of the MES subtype of GBM, significantly contributing to its stem cell features, which could open new therapeutic options. Although FOSL1/FRA-1 pharmacological inhibition is difficult to achieve due to its enzymatic activity, a gene therapy 
approach targeting FOSL1/FRA-1 expression through CRISPR/Cas9 or PROTAC, for instance, could constitute attractive alternatives to treat mesenchymal GBM patients.

\section{Materials and methods}

\section{Key resources table}

\begin{tabular}{|c|c|c|c|c|}
\hline $\begin{array}{l}\text { Reagent type } \\
\text { (species) or } \\
\text { resource }\end{array}$ & Designation & $\begin{array}{l}\text { Source or } \\
\text { reference }\end{array}$ & Identifiers & $\begin{array}{l}\text { Additional } \\
\text { information }\end{array}$ \\
\hline Antibody & $\begin{array}{l}\text { Anti-FRA-1 (Rabbit } \\
\text { polyclonal) }\end{array}$ & $\begin{array}{l}\text { Santa Cruz } \\
\text { Biotechnology }\end{array}$ & $\begin{array}{l}\text { Cat\#sc-183; } \\
\text { RRID:AB_2106928 }\end{array}$ & WB(1:1000) \\
\hline Antibody & $\begin{array}{l}\text { Anti-FRA-1 (Rabbit } \\
\text { polyclonal) }\end{array}$ & $\begin{array}{l}\text { Santa Cruz } \\
\text { Biotechnology }\end{array}$ & $\begin{array}{l}\text { Cat\#sc-605, } \\
\text { RRID:AB_2106927 }\end{array}$ & WB(1:1000) \\
\hline Antibody & $\begin{array}{l}\text { anti-CD44 (Rat } \\
\text { monoclonal) }\end{array}$ & BD Biosciences & $\begin{array}{l}\text { Cat\#550538; } \\
\text { RRID:AB_393732 }\end{array}$ & $I F(1: 100)$ \\
\hline Antibody & $\begin{array}{l}\text { Anti-S100A4 } \\
\text { (Rabbit polyclonal) }\end{array}$ & Abcam & Cat\#ab27957, RRID:AB_2183775 & $\mathrm{IHC}(1: 300)$ \\
\hline Antibody & $\begin{array}{l}\text { Anti-Ki67 } \\
\text { (Rabbit monoclonal) }\end{array}$ & $\begin{array}{l}\text { Master } \\
\text { Diagnostica }\end{array}$ & Cat\#0003100D & $\mathrm{IHC}$ (undiluted) \\
\hline Antibody & $\begin{array}{l}\text { Anti-FLAG (DYKDDDDK } \\
\text { Tag) (Rabbit } \\
\text { polyclonal) }\end{array}$ & $\begin{array}{l}\text { Cell Signaling } \\
\text { Technology }\end{array}$ & $\begin{array}{l}\text { Cat\#2368, } \\
\text { RRID:AB_2217020 }\end{array}$ & WB(1:2000) \\
\hline Antibody & $\begin{array}{l}\text { Anti-GFAP (Mouse } \\
\text { monoclonal) }\end{array}$ & Sigma-Aldrich & $\begin{array}{l}\text { Cat\#G3893, } \\
\text { RRID:AB_477010 }\end{array}$ & WB(1:5000) \\
\hline Antibody & $\begin{array}{l}\text { Anti-GFAP (Mouse } \\
\text { monoclonal) }\end{array}$ & Millipore & $\begin{array}{l}\text { Cat\#MAB360, } \\
\text { RRID:AB_11212597 }\end{array}$ & $\mathrm{IF}(1: 400)$ \\
\hline Antibody & $\begin{array}{l}\text { Anti-NF1 (Rabbit } \\
\text { polyclonal) }\end{array}$ & $\begin{array}{l}\text { Santa Cruz } \\
\text { Biotechnology }\end{array}$ & $\begin{array}{l}\text { Cat\#sc-67, } \\
\text { RRID:AB_2149681 }\end{array}$ & WB(1:500) \\
\hline Antibody & $\begin{array}{l}\text { Anti-NF1 (Rabbit } \\
\text { polyclonal) }\end{array}$ & Bethyl & $\begin{array}{l}\text { Cat\#A300-140A, } \\
\text { RRID:AB_2149790 }\end{array}$ & WB(1:1000) \\
\hline Antibody & $\begin{array}{l}\text { Anti-OLIG2 (Rabbit } \\
\text { polyclonal) }\end{array}$ & Millipore & $\begin{array}{l}\text { Cat\#AB9610, } \\
\text { RRID:AB_570666 }\end{array}$ & WB(1:2000) \\
\hline Antibody & $\begin{array}{l}\text { Anti-VIMENTIN } \\
\text { (Rabbit } \\
\text { monoclonal) }\end{array}$ & $\begin{array}{l}\text { Cell Signaling } \\
\text { Technology }\end{array}$ & $\begin{array}{l}\text { Cat\#5741, } \\
\text { RRID:AB_10695459 }\end{array}$ & WB(1:3000) \\
\hline Antibody & $\begin{array}{l}\text { Anti-phospho-p44/42 } \\
\text { MAPK (Erk1/2) } \\
\text { (Thr202/Tyr204) } \\
\text { (Rabbit polyclonal) }\end{array}$ & $\begin{array}{l}\text { Cell Signaling } \\
\text { Technology }\end{array}$ & $\begin{array}{l}\text { Cat\#9101, } \\
\text { RRID:AB_331646 }\end{array}$ & WB(1:2000) \\
\hline Antibody & $\begin{array}{l}\text { Anti-p44/42 MAPK } \\
\text { (Erk1/2) (Rabbit } \\
\text { polyclonal) }\end{array}$ & $\begin{array}{l}\text { Cell Signaling } \\
\text { Technology }\end{array}$ & $\begin{array}{l}\text { Cat\#9102, } \\
\text { RRID:AB_330744 }\end{array}$ & WB(1:1000) \\
\hline Antibody & $\begin{array}{l}\text { Anti-phospho-MEK1/2 } \\
\text { (Ser217/221) (Rabbit } \\
\text { polyclonal) }\end{array}$ & $\begin{array}{l}\text { Cell Signaling } \\
\text { Technology }\end{array}$ & $\begin{array}{l}\text { Cat\#9154, } \\
\text { RRID:AB_2138017 }\end{array}$ & WB(1:500) \\
\hline Antibody & $\begin{array}{l}\text { Anti-MEK1/2 (Rabbit } \\
\text { polyclonal) }\end{array}$ & $\begin{array}{l}\text { Cell Signaling } \\
\text { Technology }\end{array}$ & $\begin{array}{l}\text { Cat\#9122, } \\
\text { RRID:AB_823567 }\end{array}$ & WB(1:1000) \\
\hline Antibody & $\begin{array}{l}\text { Anti-human YKL40 } \\
\text { (Rabbit polyclonal) }\end{array}$ & Qidel & $\begin{array}{l}\text { Cat\#4815, } \\
\text { RRID:AB_452475 }\end{array}$ & WB(1:1000) \\
\hline Antibody & $\begin{array}{l}\text { Anti-PI3 kinase, } \\
\text { p85 } \\
\text { (Rabbit polyclonal) }\end{array}$ & Millipore & $\begin{array}{l}\text { Cat\#06-195, } \\
\text { RRID:AB_310069 }\end{array}$ & WB(1:10,000) \\
\hline Antibody & $\begin{array}{l}\text { Anti-vinculin (Mouse } \\
\text { monoclonal) }\end{array}$ & Sigma-Aldrich & $\begin{array}{l}\text { Cat\#V9131, } \\
\text { RRID:AB_477629 }\end{array}$ & WB(1:10,000) \\
\hline Antibody & $\begin{array}{l}\text { Anti- } \alpha \text {-tubulin } \\
\text { (Mouse monoclonal) }\end{array}$ & Abcam & $\begin{array}{l}\text { Cat\#ab7291, } \\
\text { RRID:AB_2241126 }\end{array}$ & WB(1:10,000) \\
\hline
\end{tabular}

Continued on next page 
Continued

\begin{tabular}{|c|c|c|c|c|}
\hline $\begin{array}{l}\text { Reagent type } \\
\text { (species) or } \\
\text { resource }\end{array}$ & Designation & $\begin{array}{l}\text { Source or } \\
\text { reference }\end{array}$ & Identifiers & $\begin{array}{l}\text { Additional } \\
\text { information }\end{array}$ \\
\hline Antibody & $\begin{array}{l}\text { Biotinylated anti- } \\
\text { rabbit lgG (Goat } \\
\text { polyclonal) }\end{array}$ & Vector Laboratories & $\begin{array}{l}\text { Cat\#BA-1000, } \\
\text { RRID:AB_2313606 }\end{array}$ & $\mathrm{IHC}(1: 200)$ \\
\hline Antibody & $\begin{array}{l}\text { Anti-rat lgG }(\mathrm{H}+\mathrm{L}) \\
\text { (goat unknown) }\end{array}$ & Vector Laboratories & $\begin{array}{l}\text { Cat\#BA-9400, } \\
\text { RRID:AB_2336202 }\end{array}$ & $\mathrm{IHC}(1: 200)$ \\
\hline Antibody & $\begin{array}{l}\text { Peroxidase-AffiniPure } \\
\text { anti-mouse IgG } \\
\text { (Goat polyclonal) }\end{array}$ & $\begin{array}{l}\text { Jackson Immuno } \\
\text { Research Labs }\end{array}$ & $\begin{array}{l}\text { Cat\#115-035-003, } \\
\text { RRID:AB_10015289 }\end{array}$ & WB(1:10,000) \\
\hline Antibody & $\begin{array}{l}\text { Peroxidase-AffiniPure } \\
\text { anti-rabbit } \\
\text { lgG (Goat } \\
\text { polyclonal) }\end{array}$ & $\begin{array}{l}\text { Jackson Immuno } \\
\text { Research Labs }\end{array}$ & $\begin{array}{l}\text { Cat\#111-035-003, } \\
\text { RRID:AB_2313567 }\end{array}$ & WB(1:10,000) \\
\hline Antibody & $\begin{array}{l}\text { Alexa Fluor } 488 \\
\text { anti-rabbit lgG } \\
(\mathrm{H}+\mathrm{L}) \\
\text { (Donkey } \\
\text { polyclonal) }\end{array}$ & $\begin{array}{l}\text { Thermo Fisher } \\
\text { Scientific }\end{array}$ & $\begin{array}{l}\text { Cat\#A21206; } \\
\text { RRID:AB_2535792 }\end{array}$ & $\mathrm{IF}(1: 400)$ \\
\hline Antibody & $\begin{array}{l}\text { Alexa Fluor } 488 \\
\text { anti-mouse } \\
\text { lgG }(\mathrm{H}+\mathrm{L}) \\
\text { (Donkey } \\
\text { polyclonal) }\end{array}$ & $\begin{array}{l}\text { Thermo Fisher } \\
\text { Scientific }\end{array}$ & $\begin{array}{l}\text { Cat\#A21202; } \\
\text { RRID:AB_141607 }\end{array}$ & $\mathrm{IF}(1: 400)$ \\
\hline Antibody & $\begin{array}{l}\text { Alexa Fluor } 594 \\
\text { anti-rat lgG }(\mathrm{H}+\mathrm{L}) \\
\text { (Donkey } \\
\text { polyclonal) }\end{array}$ & $\begin{array}{l}\text { Thermo Fisher } \\
\text { Scientific }\end{array}$ & $\begin{array}{l}\text { Cat\#A21209; } \\
\text { RRID:AB_2535795 }\end{array}$ & $\mathrm{IF}(1: 400)$ \\
\hline $\begin{array}{l}\text { Chemical } \\
\text { compound, } \\
\text { drug }\end{array}$ & Ovomucoid & Worthington & Cat\#LS003087 & \\
\hline $\begin{array}{l}\text { Chemical } \\
\text { compound, } \\
\text { drug }\end{array}$ & $\begin{array}{l}\mathrm{N} \text {-acetyl-L- } \\
\text { cysteine }\end{array}$ & Sigma-Aldrich & Cat\#A9165 & \\
\hline $\begin{array}{l}\text { Peptide, } \\
\text { recombinant } \\
\text { protein }\end{array}$ & $\begin{array}{l}\text { Recombinant } \\
\text { human EGF }\end{array}$ & Gibco & Cat\#PHG0313 & \\
\hline $\begin{array}{l}\text { Peptide, } \\
\text { recombinant } \\
\text { protein }\end{array}$ & Basic-FGF & Millipore & Cat\#GF003-AF & \\
\hline $\begin{array}{l}\text { Peptide, } \\
\text { recombinant } \\
\text { protein }\end{array}$ & Heparin & $\begin{array}{l}\text { Stem Cell } \\
\text { Technologies }\end{array}$ & Cat\#07980 & \\
\hline $\begin{array}{l}\text { Chemical } \\
\text { compound, } \\
\text { drug }\end{array}$ & L-glutamine & Hyclone & Cat\#SH3003401 & \\
\hline $\begin{array}{l}\text { Chemical } \\
\text { compound, } \\
\text { drug }\end{array}$ & Accumax & $\begin{array}{l}\text { Thermo Fisher } \\
\text { Scientific }\end{array}$ & Cat\#00-4666-56 & \\
\hline $\begin{array}{l}\text { Chemical } \\
\text { compound, } \\
\text { drug }\end{array}$ & Polybrene & Sigma-Aldrich & Cat\#H9268 & \\
\hline $\begin{array}{l}\text { Chemical } \\
\text { compound, } \\
\text { drug }\end{array}$ & Puromycin & Sigma-Aldrich & Cat\#P8833 & \\
\hline $\begin{array}{l}\text { Chemical } \\
\text { compound, } \\
\text { drug }\end{array}$ & Doxycycline & PanReac AppliChem & Cat\#A29510025 & \\
\hline
\end{tabular}

\section{Continued on next page}


Continued

\begin{tabular}{|c|c|c|c|c|}
\hline $\begin{array}{l}\text { Reagent type } \\
\text { (species) or } \\
\text { resource }\end{array}$ & Designation & $\begin{array}{l}\text { Source or } \\
\text { reference }\end{array}$ & Identifiers & $\begin{array}{l}\text { Additional } \\
\text { information }\end{array}$ \\
\hline $\begin{array}{l}\text { Chemical } \\
\text { compound, } \\
\text { drug }\end{array}$ & $\begin{array}{l}\text { Hydrogen } \\
\text { peroxide }\end{array}$ & Sigma-Aldrich & Cat\#H1009 & \\
\hline $\begin{array}{l}\text { Peptide, } \\
\text { recombinant } \\
\text { protein }\end{array}$ & BSA & Sigma-Aldrich & Cat\#A7906 & \\
\hline $\begin{array}{l}\text { Chemical } \\
\text { compound, } \\
\text { drug }\end{array}$ & BrdU & Sigma-Aldrich & Cat\#B9285 & \\
\hline $\begin{array}{l}\text { Chemical } \\
\text { compound, } \\
\text { drug }\end{array}$ & $\begin{array}{l}\text { Peroxidase } \\
\text { substrate DAB }\end{array}$ & Vector Laboratories & Cat\#SK-4100 & \\
\hline $\begin{array}{l}\text { Chemical } \\
\text { compound, } \\
\text { drug }\end{array}$ & TRIzol & Invitrogen & Cat\#15596-026 & \\
\hline $\begin{array}{l}\text { Chemical } \\
\text { compound, } \\
\text { drug }\end{array}$ & MTT & Sigma-Aldrich & Cat\#M5655 & \\
\hline $\begin{array}{l}\text { Chemical } \\
\text { compound, } \\
\text { drug }\end{array}$ & $\mathrm{PI}$ & Sigma-Aldrich & Cat\#P4170 & \\
\hline Other & Goat serum & Sigma-Aldrich & Cat\#G9023 & \\
\hline Other & RNase A & Roche & Cat\#10109142001 & \\
\hline Other & DAPI & Sigma-Aldrich & Cat\#D8417 & \\
\hline Other & $\begin{array}{l}\text { ProLong } \\
\text { Gold Antifade }\end{array}$ & Invitrogen & Cat\#P10144 & \\
\hline Other & $\begin{array}{l}\text { Protein A/G plus- } \\
\text { agarose beads }\end{array}$ & $\begin{array}{l}\text { Santa Cruz } \\
\text { Biotechnology }\end{array}$ & Cat\#sc-2003 & \\
\hline Other & $\begin{array}{l}\text { Salmon } \\
\text { sperm DNA }\end{array}$ & $\begin{array}{l}\text { Thermo Fisher } \\
\text { Scientific }\end{array}$ & Cat\#AM9680 & \\
\hline Other & Neurobasal medium & Gibco & Cat\#10888022 & \\
\hline Other & B27 supplement & Gibco & Cat\#12587010 & \\
\hline Other & N2 supplement & Gibco & Cat\#17502048 & \\
\hline Other & $\begin{array}{l}\text { Earl's Balanced } \\
\text { Salt Solution }\end{array}$ & Gibco & Cat\#14155-08 & \\
\hline Other & Papain & Worthington & Cat\#LS003119 & \\
\hline Other & DNasel & Roche & Cat\#10104159001 & \\
\hline Other & $\begin{array}{l}\text { Mouse NeuroCult } \\
\text { basal medium }\end{array}$ & $\begin{array}{l}\text { Stem Cell } \\
\text { Technologies }\end{array}$ & Cat\#05700 & \\
\hline Other & $\begin{array}{l}\text { Mouse NeuroCult } \\
\text { Proliferation } \\
\text { supplement }\end{array}$ & $\begin{array}{l}\text { Stem Cell } \\
\text { Technologies }\end{array}$ & Cat\#05701 & \\
\hline Other & ACK lysing buffer & Gibco & Cat\#A1049201 & \\
\hline Other & DMEM & Sigma-Aldrich & Cat\#D5796 & \\
\hline $\begin{array}{l}\text { Commercial } \\
\text { assay or kit }\end{array}$ & $\begin{array}{l}\text { High Capacity } \\
\text { cDNA } \\
\text { Reverse } \\
\text { Transcription Kit }\end{array}$ & Applied Biosystems & Cat\#4368814 & \\
\hline $\begin{array}{l}\text { Commercial } \\
\text { assay or kit }\end{array}$ & $\begin{array}{l}\text { SYBR Select } \\
\text { Master Mix }\end{array}$ & Applied Biosystems & Cat\#4472908 & \\
\hline $\begin{array}{l}\text { Commercial } \\
\text { assay or kit }\end{array}$ & $\begin{array}{l}\text { Superscriptlll reverse } \\
\text { transcriptase }\end{array}$ & Life Technologies & Cat\#18080-085 & \\
\hline
\end{tabular}

\section{Continued on next page}


Continued

\begin{tabular}{|c|c|c|c|c|}
\hline $\begin{array}{l}\text { Reagent type } \\
\text { (species) or } \\
\text { resource }\end{array}$ & Designation & $\begin{array}{l}\text { Source or } \\
\text { reference }\end{array}$ & Identifiers & $\begin{array}{l}\text { Additional } \\
\text { information }\end{array}$ \\
\hline $\begin{array}{l}\text { Commercial } \\
\text { assay or kit }\end{array}$ & $\begin{array}{l}\text { QuantSeq } 3^{\prime} \\
\text { mRNA-Seq } \\
\text { Library Prep } \\
\text { Kit (FWD) } \\
\text { for Illumina }\end{array}$ & Lexogen & Cat\#015 & \\
\hline $\begin{array}{l}\text { Commercial } \\
\text { assay or kit }\end{array}$ & $\begin{array}{l}\text { StemPro Osteogenesis } \\
\text { Differentiation Kit }\end{array}$ & Life Technologies & Cat\#A1007201 & \\
\hline $\begin{array}{l}\text { Commercial } \\
\text { assay or kit }\end{array}$ & $\begin{array}{l}\text { Active Ras pull } \\
\text { down assay kit }\end{array}$ & $\begin{array}{l}\text { Thermo Fisher } \\
\text { Scientific }\end{array}$ & Cat\#16117 & \\
\hline $\begin{array}{l}\text { Commercial } \\
\text { assay or kit }\end{array}$ & $\begin{array}{l}\text { QIAquick PCR } \\
\text { purification kit }\end{array}$ & QIAGEN & Cat\#28104 & \\
\hline $\begin{array}{l}\text { Commercial } \\
\text { assay or kit }\end{array}$ & $\begin{array}{l}\text { QIAGEN PCR } \\
\text { cloning kit }\end{array}$ & QIAGEN & Cat\#231124 & \\
\hline $\begin{array}{l}\text { Recombinant } \\
\text { DNA reagent }\end{array}$ & $\begin{array}{l}\text { PCHMWS- } \\
\text { NF1-GRD }\end{array}$ & This paper & $\mathrm{N} / \mathrm{A}$ & $\begin{array}{l}\text { NF1-GRD overexpressing } \\
\text { construct } \\
\text { generated } \\
\text { in the } \\
\text { Carro's lab }\end{array}$ \\
\hline $\begin{array}{l}\text { Recombinant } \\
\text { DNA reagent }\end{array}$ & pLKO-shNF1 & Sigma-Aldrich & TRCN0000238778 & \\
\hline $\begin{array}{l}\text { Recombinant } \\
\text { DNA reagent }\end{array}$ & pGIPZ-shNF1 & This paper & N/A & $\begin{array}{l}\text { Human NF1 } \\
\text { shRNA construct } \\
\text { generated in } \\
\text { the Carro's lab }\end{array}$ \\
\hline $\begin{array}{l}\text { Recombinant } \\
\text { DNA reagent }\end{array}$ & $\begin{array}{l}\text { pGIPZ-shNF1 clone } \\
\text { V2LHS_76027 (clone 4) }\end{array}$ & Open Biosystems & $\begin{array}{l}\text { RHS4430- } \\
98894408\end{array}$ & \\
\hline $\begin{array}{l}\text { Recombinant } \\
\text { DNA reagent }\end{array}$ & $\begin{array}{l}\text { pGIPZ-shNF1 clone } \\
\text { V2LHS_260806 } \\
\text { (clone 5) }\end{array}$ & Open Biosystems & $\begin{array}{l}\text { RHS4430- } \\
98912463\end{array}$ & \\
\hline $\begin{array}{l}\text { Recombinant } \\
\text { DNA reagent }\end{array}$ & $\begin{array}{l}\text { PKLV-U6gRNA- } \\
\text { PGKpuro2ABFP }\end{array}$ & $\begin{array}{l}\text { Kosuke Yusa } \\
\text { (Wellcome } \\
\text { Sanger Institute) }\end{array}$ & $\begin{array}{l}\text { Addgene } \\
\text { plasmid \#50946 }\end{array}$ & \\
\hline $\begin{array}{l}\text { Recombinant } \\
\text { DNA reagent }\end{array}$ & pLVX-Cre & Maria A. Blasco (CNIO) & $\mathrm{N} / \mathrm{A}$ & \\
\hline $\begin{array}{l}\text { Recombinant } \\
\text { DNA reagent }\end{array}$ & $\begin{array}{l}\text { PLKO.1-TET- } \\
\text { shFOSL1_3 and } \\
\text { shFOSL1_10 }\end{array}$ & Silve Vicent (CIMA) & $\mathrm{N} / \mathrm{A}$ & \\
\hline $\begin{array}{l}\text { Recombinant } \\
\text { DNA reagent }\end{array}$ & pMD2.G & Carro's lab & $\begin{array}{l}\text { Addgene } \\
\text { plasmid \#12259 }\end{array}$ & \\
\hline $\begin{array}{l}\text { Recombinant } \\
\text { DNA reagent }\end{array}$ & psPAX2 & Carro's lab & $\begin{array}{l}\text { Addgene } \\
\text { plasmid \#12260 }\end{array}$ & \\
\hline $\begin{array}{l}\text { Recombinant } \\
\text { DNA reagent }\end{array}$ & pBabe-FOSL1 & Matsuo et al., 2000 & N/A & \\
\hline $\begin{array}{l}\text { Recombinant } \\
\text { DNA reagent }\end{array}$ & $\begin{array}{l}\text { pSIN-EF1-puro- } \\
\text { FLAG-FOSL1 }\end{array}$ & Silve Vicent (CIMA) & N/A & \\
\hline $\begin{array}{l}\text { Recombinant } \\
\text { DNA reagent }\end{array}$ & pSIN-EF1-puro-eGFP & Silve Vicent (CIMA) & $\mathrm{N} / \mathrm{A}$ & \\
\hline $\begin{array}{l}\text { Recombinant } \\
\text { DNA reagent }\end{array}$ & RCAS-sgNf1 & This paper & $\mathrm{N} / \mathrm{A}$ & $\begin{array}{l}\text { Mouse Nf1 sgRNA } \\
\text { construct generated } \\
\text { in the Squatrito's lab }\end{array}$ \\
\hline $\begin{array}{l}\text { Recombinant } \\
\text { DNA reagent }\end{array}$ & RCAS-shNf1 & Ozawa et al., 2014 & $\mathrm{~N} / \mathrm{A}$ & \\
\hline
\end{tabular}

Continued on next page 
Continued

\begin{tabular}{|c|c|c|c|c|}
\hline $\begin{array}{l}\text { Reagent type } \\
\text { (species) or } \\
\text { resource }\end{array}$ & Designation & $\begin{array}{l}\text { Source or } \\
\text { reference }\end{array}$ & Identifiers & $\begin{array}{l}\text { Additional } \\
\text { information }\end{array}$ \\
\hline $\begin{array}{l}\text { Recombinant } \\
\text { DNA reagent }\end{array}$ & RCAS-KrasG12V & This paper & $\mathrm{N} / \mathrm{A}$ & $\begin{array}{l}\text { KRASG12V construct } \\
\text { generated } \\
\text { in the } \\
\text { Squatrito's lab }\end{array}$ \\
\hline $\begin{array}{l}\text { Software, } \\
\text { algorithm }\end{array}$ & FlowJo v10 & $\begin{array}{l}\text { BD (Becton, } \\
\text { Dickinson and } \\
\text { Company) }\end{array}$ & N/A & \\
\hline $\begin{array}{l}\text { Software, } \\
\text { algorithm }\end{array}$ & RStudio & $\begin{array}{l}\text { https://rstudio. } \\
\text { com/products/rstudio/ }\end{array}$ & N/A & \\
\hline $\begin{array}{l}\text { Software, } \\
\text { algorithm }\end{array}$ & $\begin{array}{l}\text { Nextpresso } \\
\text { RNA-Seq pipeline }\end{array}$ & Graña et al., 2018 & $\begin{array}{l}\text { https://hub.docker. } \\
\text { com/r/osvaldoge/ } \\
\text { nextpresso }\end{array}$ & \\
\hline $\begin{array}{l}\text { Software, } \\
\text { algorithm }\end{array}$ & deepTools2 & Ramírez et al., 2016 & $\begin{array}{l}\text { https://deeptools. } \\
\text { readthedocs.io/ } \\
\text { en/develop/ }\end{array}$ & \\
\hline $\begin{array}{l}\text { Software, } \\
\text { algorithm }\end{array}$ & bowtie2 v2.3.5 & $\begin{array}{l}\text { Langmead and } \\
\text { Salzberg, } 2012\end{array}$ & $\begin{array}{l}\text { Bowtie 2, } \\
\text { RRID:SCR_016368 }\end{array}$ & \\
\hline $\begin{array}{l}\text { Software, } \\
\text { algorithm }\end{array}$ & SeqMonk & $\begin{array}{l}\text { https://www. } \\
\text { bioinformatics. } \\
\text { babraham.ac.uk/ } \\
\text { projects/seqmonk/ }\end{array}$ & $\begin{array}{l}\text { SeqMonk, } \\
\text { RRID:SCR_001913 }\end{array}$ & \\
\hline $\begin{array}{l}\text { Software, } \\
\text { algorithm }\end{array}$ & ChaSE & Younesy et al., 2016 & $\begin{array}{l}\text { http://chase.cs. } \\
\text { univie.ac.at/ } \\
\text { overview }\end{array}$ & \\
\hline $\begin{array}{l}\text { Software, } \\
\text { algorithm }\end{array}$ & GSEA & Subramanian et al., 2005 & $\begin{array}{l}\text { Gene Set } \\
\text { Enrichment } \\
\text { Analysis, } \\
\text { RRID:SCR_003199 }\end{array}$ & \\
\hline $\begin{array}{l}\text { Software, } \\
\text { algorithm }\end{array}$ & $\begin{array}{l}\text { R programming } \\
\text { language }\end{array}$ & R Core team 2013 & $\begin{array}{l}\text { R Project for } \\
\text { Statistical Computing, } \\
\text { RRID:SCR_001905 }\end{array}$ & \\
\hline $\begin{array}{l}\text { Software, } \\
\text { algorithm }\end{array}$ & trim-galore v0.6.2 & $\begin{array}{l}\text { https://www. } \\
\text { bioinformatics. } \\
\text { babraham.ac.uk/ } \\
\text { projects/trim_galore/ }\end{array}$ & N/A & \\
\hline $\begin{array}{l}\text { Cell line } \\
\text { (Gallus gallus) }\end{array}$ & DF1 & ATCC & Cat\#CRL-12203 & \\
\hline $\begin{array}{l}\text { Cell line } \\
\text { (Homo sapiens) }\end{array}$ & Gp2-293 & Clontech & Cat\#631458 & \\
\hline $\begin{array}{l}\text { Cell line } \\
\text { (Homo sapiens) }\end{array}$ & BTSC 232 & Fedele et al., 2017 & $\mathrm{~N} / \mathrm{A}$ & \\
\hline $\begin{array}{l}\text { Cell line } \\
\text { (Homo sapiens) }\end{array}$ & $\begin{array}{l}\text { BTSC 233, BTSC } \\
\text { 3021, } \\
\text { BTSC 3047, BTSC } \\
\text { 349, BTSC } 380\end{array}$ & This paper & N/A & $\begin{array}{l}\text { Human patient- } \\
\text { derived lines } \\
\text { generated at Freiburg } \\
\text { University; see } \\
\text { Materials and } \\
\text { methods for details }\end{array}$ \\
\hline $\begin{array}{l}\text { Cell line } \\
\text { (Homo sapiens) }\end{array}$ & h543, h676 & Ozawa et al., 2014 & $\mathrm{~N} / \mathrm{A}$ & \\
\hline
\end{tabular}

\section{Generation of the BTSCs dataset and MRA}

The BTSC lines dataset $(n=144)$ was assembled with new and previously generated transcriptomic data: 22 Illumina HumanHT-12v4 expression BeadChip microarrays newly generated at Freiburg University (GSE137310, this study), 44 RNA-seq samples (Illumina HiSeq 2500) from GSE119834 (Mack et al., 2019), 14 RNA-seq samples (Illumina HiSeq 2000) from SRP057855 (Cusulin et al., 
2015), 30 Affymetrix Human Genome U219 microarrays from GSE67089 (Mao et al., 2013), 17 Affymetrix Human Genome U133 Plus 2.0 microarrays from GSE8049 (Günther et al., 2008), and 17 Affymetrix GeneChip Human Genome U133A 2.0 microarrays from GSE49161 (Bhat et al., 2013). To analyze the RNA-seq samples, we used the Nextpresso pipeline (Graña et al., 2018). For the Affymetrix microarrays, raw data were downloaded from the GEO repository (https://www.ncbi.nlm. nih.gov/geo/) and subsequently the 'affy' R package (Gautier et al., 2004) was used for robust multi-array average normalization followed by quantile normalization. For genes with several probe sets, the median of all probes had been chosen and only common genes among all the datasets $(n=$ 9889) were used for further analysis. To avoid issues with the use of different transcriptomic platforms, each dataset was then scaled (mean $=0, S D=1$ ) before assembling the combined final dataset. Transcriptional subtypes were obtained using the 'ssgsea.GBM.classification' $R$ package (Wang et al., 2017), using 1000 permutations. For differential gene expression studies, we selected the 133 BTSCs lines that had concordant ssGSEA results, with MES BTSCs classified both as MES and INJ and non-MES BTSCs classified both as PN/CL and DEV. Differential gene expression (MES vs. non-MES BTSCs) was performed using the 'limma' R package (Ritchie et al., 2015), taking into account the possible batch differences due the different datasets assembled.

The MRA was performed using the 'RTN' R package (Castro et al., 2016). Normalized BTSC expression data were used as input to build a transcriptional network (TN) for 887 TFs present in the dataset. TF annotations were obtained from the human TF atlas version 1.0.1 (http://humantfs.ccbr. utoronto.ca/) (Lambert et al., 2018). p-Values for network edges were computed from a pooled null distribution using 1000 permutations. Edges with an adjusted-p-value $<0.05$ were kept for data processing inequality (DPI) filtering. In the TN, each target can be connected to multiple TFs and regulation can occur as a result of both direct and indirect interactions. DPI filtering removes the weakest interaction in any triangle of two TFs and a target gene, therefore preserving the dominant TF-target pairs and resulting in a filtered TN that highlights the most significant interactions (Fletcher et al., 2013). Post-DPI filtering, the MRA computes the overlap between the transcriptional regulatory unities (regulons) and the input signature genes using the hypergeometric distribution (with multiple hypothesis testing corrections). To identify MRs, the differential gene expression between MES and non-MES was used as a phenotype.

\section{TCGA and CGGA data analysis}

RSEM normalized RNA-seq data for the TCGA GBMLGG and CGGA datasets were downloaded from the Broad Institute Firebrowse (http://gdac.broadinstitute.org) and the Chinese Glioma Genome Atlas (updated November 2019) (http://www.cgga.org.cn/), respectively. NF1 copy number alterations and point mutations for the TCGA GBMLGG were obtained at the cBioPortal (https:// www.cbioportal.org). FOSL1 expression and NF1 mutational status for the TCGA datasets in Figure 8-figure supplement 1 were obtained from the Timer2.0 web portal (http://timer.cistrome. org/) (Li et al., 2020). Transcriptional subtypes were inferred using the 'ssgsea.GBM.classification' R package as indicated above. Glioma molecular subtypes information was downloaded from the GlioVis web portal (http://gliovis.bioinfo.cnio.es) (Bowman et al., 2017). Survival analysis was performed using the 'survival' R package. Stratification of the patients has been done by comparing the patients with the $30 \%$ FOSL1 high expression to the $30 \%$ FOSL1 low expression.

\section{SCRNA-seq datasets}

Preprocessed scRNA-seq data were downloaded from the Broad Institute Single-Cell Portal (https:// singlecell.broadinstitute.org/single_cell/), study numbers SCP503 (Richards et al., 2021) and SCP393 (Neftel et al., 2019).

\section{Gene expression array and GSEA}

For gene expression profiling of the BTSC lines of the Freiburg dataset, total RNA was prepared using the RNeasy kit (QIAGEN \#74104) or the AllPrep DNA/RNA/Protein mini kit (QIAGEN \#80004) and quantified using 2100 Bioanalyzer (Agilent). One-and-a-half microgram of total RNA for each sample was sent to the genomic facility of the German Cancer Research Center (DKFZ) in Heidelberg (Germany), where hybridization and data normalization were performed. Hybridization was carried out on Illumina HumanHT-12v4 expression BeadChip. GSEA was performed using the GSEA 
software (http://www.broadinstitute.org/gsea/index.jsp) (Subramanian et al., 2005). Gene signatures are listed in Supplementary file 5.

\section{ATAC-seq}

ATAC-seq was performed on 60,000 p53-null Kras ${ }^{\mathrm{G} 12 \mathrm{~V}}$ mouse NSCs transduced with either sgFosl1_1, sgFosl1_3, or sgCtrl. Briefly, the cells were pelleted in PBS and tagmentation was performed in either $50 \mu \mathrm{L}$ of master mix containing $25 \mu \mathrm{L} 2$ xTD buffer, $2.5 \mu \mathrm{L}$ transposase, and $22.5 \mu \mathrm{L}$ nuclease-free water (Nextera DNA Library Prep, Illumina \#FC-121-1030) or in $50 \mu \mathrm{L}$ of tagmentation mix containing $25 \mu \mathrm{L}$ of TAPS-DMF buffer ( $80 \mathrm{mM}$ TAPS, $40 \mathrm{mM} \mathrm{MgCl} 2,50 \%$ vol/vol DMF), $0.625 \mu \mathrm{L}$ in-house-produced hyperactive Tn5 enzyme and $24.4 \mu \mathrm{L}$ nuclease-free water (adapted from Hennig et al., 2018). The tagmentation reactions were incubated for $1 \mathrm{hr}$ at $37^{\circ} \mathrm{C}$ with moderate agitation (500-800 rpm). After the incubation, $5 \mu \mathrm{L}$ of Proteinase $\mathrm{K}$ (Invitrogen \#AM2548) were added to the samples to stop the transposition. The cells were subsequently lysed by adding $50 \mu \mathrm{L}$ of $\mathrm{AL}$ buffer (QIAGEN \#19075) and incubating for $10 \mathrm{~min}$ at $56^{\circ} \mathrm{C}$. The DNA was extracted by means of $1.8 \times \mathrm{vol} / \mathrm{vol}$ AMPure XP beads (Beckman Coulter \#A63881) and eluted in $18 \mu \mathrm{L}$. To determine the optimal number of PCR cycles required for library amplification, $2 \mu \mathrm{L}$ of each sample were taken as template for qPCR using KAPA HiFi HotStart ReadyMix (Roche \#7958927001) and 1xEvaGreen Dye (Biotium \#31000). The whole probe amplification was performed in $50 \mu \mathrm{L}$ qPCR volume with 8-12 $\mu \mathrm{L}$ of template DNA. Primers were previously described (Buenrostro et al., 2013). Each library was individually quantified utilizing the Qubit 3.0 Fluorometer (Life Technologies). The appropriate ATAC-seq libraries laddering pattern was determined with TapeStation High Sensitivity D1000 ScreenTapes (Agilent \#5067-5584). The libraries were sequenced on the Illumina NextSeq500 using the High Output V2 150 cycles chemistry kit in a $2 \times 75$ bp mode.

\section{ATAC-seq analysis}

The reads were adaptor-trimmed using the trim-galore v0.6.2 -nextera (https://www.bioinformatics.babraham.ac.uk/projects/trim_galore/). The mapping was conducted using the bowtie2 v2.3.5 (Langmead and Salzberg, 2012) default parameters. The differential chromatin accessibility analysis was performed in SeqMonk taking mouse CpG islands ( $\mathrm{mCGl}$ ) and TSSs $\pm 500 \mathrm{bp}$ as the probe set (GRCm38 assembly). Counts were normalized by means of the 'Read Count Quantification' function with additional correction for total count (CPM), log transformation, and size factor normalization. The differential accessibility between the Fos/1-WT and Fos/1-depleted cells was determined utilizing the limma pipeline (Ritchie et al., 2015).

The 'chromVAR' R package (Schep et al., 2017) was used to analyze the chromatin accessibility data, perform corrections for known technical biases, and identify motifs with differential deviation in chromatin accessibility between the samples. The enrichGO function from the 'clusterProfiler' R package (Yu et al., 2012) was used to visualize the relevant pathways in Figure 4D, E. The bamCoverage function of the deepTools2 tool (Ramírez et al., 2016) was used to generate BigWig from aligned files for subsequent visualization with the 'karyoploteR' R package (Gel and Serra, 2017).

\section{ChIP-seq analysis}

We downloaded FOSL1 ChIP-seq profiling from the KRAS mutant HCT116 cell line ENCODE tracks ENCFF000OZR and ENCFF000OZQ. FOSL1/FRA-1 peaks $(29,738)$ were identified with SeqMonk using the MACS algorithm (Zhang et al., 2008) with a $10^{-7} \mathrm{p}$-value cutoff. OLIG2 binding sites and ChIP-seq profiles were downloaded from GEO: GSM1306365_MGG8TPC.OLIG2r1c and GSM1306367_MGG8TPC.OLIG2r2 (Suvà et al., 2014). H3K27Ac data were downloaded from GSE119755 (Mack et alı, 2019) for GSM3382275_GSC1_H3K27AC, GSM3382277_GSC10_H3K27AC, GSM3382285_GSC14_H3K27AC, GSM3382289_GSC16_H3K27AC, GSM3382291_GSC17_H3K27AC, GSM3382293_GSC18_H3K27AC, GSM3382295_GSC19_H3K27AC, GSM3382299_GSC20_H3K27AC, GSM3382303_GSC22_H3K27AC, GSM3382313_GSC27_H3K27AC, GSM3382319_GSC3_H3K27AC, GSM3382327_GSC33_H3K27AC, GSM3382331_GSC35_H3K27AC, GSM3382333_GSC36_H3K27AC, GSM3382341_GSC4_H3K27AC, GSM3382343_GSC40_H3K27AC, GSM3382345_GSC41_H3K27AC, GSM3382347_GSC43_H3K27AC, GSM3382351_GSC5_H3K27AC, GSM3382355_GSC7_H3K27AC. Quantitation was Read Count Quantitation using all reads correcting for total count only in probes normalized to the largest store, log transformed, and duplicates 
ignored. Differential H3K27Ac signal was measured through the DESeq2 pipeline (Love et al., 2014). Heatmaps were generated with ChaSE (Younesy et al., 2016), plotting H3K27AC signal over FOSL1 (3532 probes, MES vs. non-MES log2 fold-change >2) or OLIG2 (15800 probes) peaks, with a 10,000 bp probe window.

\section{Mouse strains and husbandry}

GFAP-tv-a; hGFAP-Cre; Rosa26-LSL-Cas9 mice were previously described (Oldrini et al., 2018). Kras $^{\text {LSLG12V }}$; Trp53 ${ }^{\text {lox }} ;$ Rosa26 $6^{\text {LSLrtTA-IRES-EGFP }}$; Col1a $1^{\text {TetO-Fosl1 }}$ mouse strain corresponds to the MGI Allele References 3582830, 1931011, 3583817, and 5585716, respectively. Immunodeficient nu/nu mice (MGI: 1856108) were obtained at the Spanish National Cancer Research Centre Animal Facility.

Mice were housed in the specific pathogen-free animal house of the Spanish National Cancer Research Centre under conditions in accordance with the recommendations of the Federation of European Laboratory Animal Science Associations (FELASA). All animal experiments were approved by the Ethical Committee (CElyBA) (\# CBA 31_2019-V2) and performed in accordance with the guidelines stated in the International Guiding Principles for Biomedical Research Involving Animals, developed by the Council for International Organizations of Medical Sciences (CIOMS).

\section{Cell lines, cell culture, and drug treatments}

Mouse NSCs were derived from the whole brain of newborn mice of Gtv-a; hGFAP-Cre; LSL-Cas9; $\operatorname{Trp53}^{\text {lox }}$ (referred to as p53-null NSCs) and Kras ${ }^{\text {LSLG12V. }}$ Trp53 ${ }^{\text {lox }} ;$ Rosa26 $^{\text {LSLrTTA-IRES-EGFP }}$; Col1a1 ${ }^{\text {TetO- }}$

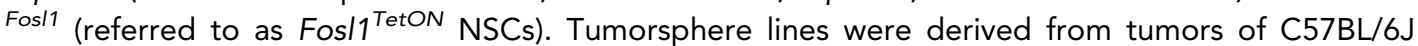
injected with Fos $11^{\text {TetON }}$ NSCs when mice were sacrificed after showing symptoms of brain tumor disease. For the derivation of mouse NSCs and tumorspheres, tissue was enzymatically digested with $5 \mathrm{~mL}$ of papain digestion solution $(0.94 \mathrm{mg} / \mathrm{mL}$ papain [Worthington \#LS003119], $0.48 \mathrm{mM}$ EDTA, $0.18 \mathrm{mg} / \mathrm{mL} \mathrm{N}$-acetyl-L-cysteine [Sigma-Aldrich \#A9165] in Earl's Balanced Salt Solution [Gibco \#14155-08]) and incubated at $37^{\circ} \mathrm{C}$ for $8 \mathrm{~min}$. After digestion, the enzyme was inactivated by the addition of $2 \mathrm{~mL}$ of $0.71 \mathrm{mg} / \mathrm{mL}$ ovomucoid (Worthington \#LS003087) and $0.06 \mathrm{mg} / \mathrm{mL}$ DNasel (Roche \#10104159001) diluted in Mouse NeuroCult basal medium (Stem Cell Technologies \#05700) without growth factors. Cell suspension was centrifuged at a low speed and then passed through a $40 \mu \mathrm{m}$ mesh filter to remove undigested tissue, washed first with PBS and then with ACK lysing buffer (Gibco \#A1049201) to remove red blood cells. NSCs and tumorspheres were grown in Mouse NeuroCult basal medium, supplemented with Proliferation supplement (Stem Cell Technologies \#05701), $20 \mathrm{ng} / \mathrm{mL}$ recombinant human EGF (Gibco \#PHG0313), $10 \mathrm{ng} / \mathrm{mL}$ basic-FGF (Millipore \#GF003-AF), $2 \mu \mathrm{g} / \mathrm{mL}$ heparin (Stem Cell Technologies \#07980), and L-glutamine (2 mM, Hyclone \#SH3003401). Spheres were dissociated with Accumax (Thermo Fisher Scientific \#00-4666-56) and re-plated every 4-5 days.

Patient-derived GBM stem cells (BTSCs) from Freiburg University were prepared from tumor specimens under IRB-approved guidelines (\#407/09_120965) as described before (Fedele et al., 2017). The gender of the main BTSCs lines used in this study are BTSC 232 (male), BTSC 233 (female), BTSC 349 (female), and BTSC 380 (male). BTSCs were grown as neurospheres in Neurobasal medium (Gibco \#10888022) containing B27 supplement (Gibco \#12587010), N2 supplement (Gibco \#17502048), b-FGF (20 ng/mL), EGF (20 ng/mL), LIF (10 ng/mL, CellGS \#GFH200-20), and 2 $\mu \mathrm{g} / \mathrm{mL}$ heparin and L-glutamine (2 mM). Patient-derived GBM stem cell lines h543 and h676, kindly provided by Eric C. Holland, were grown as neurospheres Human NeuroCult basal medium, supplemented with Proliferation supplement (Stem Cell Technologies \#05751) and growth factors, as the mouse NSCs or tumorspheres (see above). BTSC 380 were differentiated by culturing them for 5 days with $0.5 \%$ FBS and $5 \mathrm{ng} / \mathrm{mL}$ of TNFalpha (Tebu-bio \#300-01A-A) (Schmitt et al., 2021). All cell lines used were routinely tested for mycoplasma contamination by PCR.

The MAPK inhibitors GDC-0623, trametinib, and U0126 were purchased from Merck (Cat\# AMBH303C5C40), Selleckchem (Cat\# S2673), and Sigma-Aldrich (Cat\# 662005), respectively.

\section{Vectors, virus production, and infection}

Flag-tagged NF1-GRD (aminoacids 1131-1534) was amplified by PCR from human cortical tissue (epilepsy patient) and first cloned in the pDRIVE vector (QIAGEN \#231124). Primers are listed in Supplementary file 6 . The NF1-GRD sequence was then excised by restriction digestion using Pmel 
and Spel enzymes and subcloned in the modified pCHMWS lentiviral vector (kind gift from V. Baekelandt, University of Leuven, Belgium) sites by removing the fLUC region. The correct sequence was verified by sequencing. For NF1 silencing, shNF1 from pLKO (Sigma, TRCN0000238778) (shNF1_1) was subcloned in pGIPZ lentiviral vector (Open Biosystems). The corresponding short hairpin sequence was synthetized (GATC) and amplified by PCR using Xhol and EcoRI sites containing primers. The PCR product was digested using Xhol and EcoRI and subcloned into the pGIPZ vector previously digested with $\mathrm{Xhol}$ and Pmel followed by digestion with EcoRI. The two vector fragments were ligated with NF1 short hairpin fragment. The correct insertion and sequence was validated by sequencing. In addition, experiments were performed using shNF1-pGIPZ clone V2LHS_76027 (shNF1_4) and V2LHS_260806 (shNF1_5).

RCAS viruses (RCAS-shNf1, RCAS-sgNf1, and RCAS-Kras ${ }^{\mathrm{G} 12 \mathrm{~V}}$ ) used for infection of p53-null NSCs were obtained from previously transfected DF1 chicken fibroblasts (ATCC \#CRL-12203) using FuGENE 6 Transfection reagent (Promega \#E2691), according to the manufacturer's protocol. DF1 cells were grown at $39^{\circ} \mathrm{C}$ in DMEM containing GlutaMAX (Gibco \#31966-021) and 10\% FBS (SigmaAldrich \#F7524).

The pKLV-U6gRNA-PGKpuro2ABFP was a gift from Dr. Kosuke Yusa (Wellcome Sanger Institute) (Addgene plasmid \#50946). For cloning of single gRNAs, oligonucleotides containing the Bbsl site and the specific gRNA sequences were annealed, phosphorylated, and ligated into the pKLVU6gRNA(Bbsl)-PGKpuro2ABFP previously digested with Bbsl. Single gRNAs to target Fos/1 were designed with Guide Scan (http://www.guidescan.com/) and the sequences cloned were sgFos/1_1: TACCGAGACTACGGGGAACC; sgFos/1_2: CCTAGGGCTCGTATGACTCC; sgFos/1_3: ACCG TACGGGCTGCCAGCCC. These vectors and a non-targeting sgRNA control were used to transduce p53-null Kras ${ }^{G 12 V}$ NSCs.

The pLVX-Cre and respective control vector were kindly provided by Dr. Maria Blasco (CNIO) and

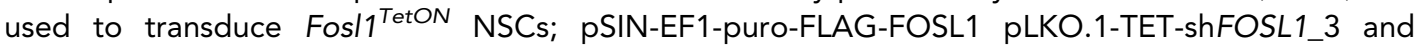
shFOSL1_10 and respective control vectors were a gift from Dr. Silve Vicent (CIMA, Navarra University); pBabe-FOSL1 was previously described (Matsuo et al., 2000).

Gp2-293 packaging cell line (Clontech \#631458) was grown in DMEM (Sigma-Aldrich \#D5796) with $10 \%$ FBS. Lentiviruses generated in this cell line were produced using calcium-phosphate precipitate transfection and co-transfected with second-generation packaging vectors (pMD2G and psPAX2). High-titer virus was collected at 36 and $60 \mathrm{hr}$ following transfection.

All cells were infected with lenti- or retroviruses by four cycles of spin infection (200 $\times \mathrm{g}$ for $2 \mathrm{hr}$ ) in the presence of $8 \mu \mathrm{g} / \mathrm{mL}$ polybrene (Sigma-Aldrich \#H9268). Transduced cells were selected after $48 \mathrm{hr}$ from the last infection with $1 \mu \mathrm{g} / \mathrm{mL}$ puromycin (Sigma-Aldrich \#P8833).

\section{Generation of murine gliomas p53-null Kras ${ }^{\text {G12V }}$}

Fosl1 ${ }^{\text {TetON }}$ NSCs $\left(5 \times 10^{5}\right.$ cells) were intracranially injected into 4- to 5-week-old wildtype C57BI/6J female mice that were fed ad libitum with $2 \mathrm{~g} / \mathrm{kg}$ doxycycline-containing pellets. Due to the limited penetration of the blood-brain barrier and to ensure enough Dox was reaching the brain, $2 \mathrm{mg} / \mathrm{mL}$ Dox (PanReac AppliChem \#A29510025) was also added to drinking water with 1\% sucrose (SigmaAldrich \#S0389) (Annibali et al., 2014; Mansuy and Bujard, 2000). Control mice were kept with regular food and $1 \%$ sucrose drinking water.

Mice were anesthetized with $4 \%$ isofluorane and then injected with a stereotactic apparatus (Stoelting) as previously described (Hambardzumyan et al., 2009). After intracranial injection, all mice were routinely checked and sacrificed when developed symptoms of disease (lethargy, poor grooming, weight loss, and macrocephaly).

\section{Immunohistochemistry}

Tissue samples were fixed in $10 \%$ formalin, paraffin-embedded, and cut in $3 \mu \mathrm{m}$ sections, which were mounted in Superfrost Plus microscope slides (Thermo Scientific \#J1810AMNZ) and dried. Tissues were deparaffinized in xylene and re-hydrated through graded concentrations of ethanol in water, ending in a final rinse in water.

For histopathological analysis, sections were stained with hematoxylin and eosin (H\&E).

For immunohistochemistry, deparaffinized sections underwent heat-induced antigen retrieval, endogenous peroxidase activity was blocked with $3 \%$ hydrogen peroxide (Sigma-Aldrich \#H1009) 
for $15 \mathrm{~min}$, and slides were then incubated in blocking solution (2.5\% BSA [Sigma-Aldrich \#A7906] and 10\% Goat serum [Sigma-Aldrich \#G9023], diluted in PBS) for at least $1 \mathrm{hr}$. Incubations with antiFRA-1 (Santa Cruz \#sc-183, 1:100) and anti-CD44 (BD Biosciences \#550538, 1:100) were carried out overnight at $4^{\circ} \mathrm{C}$. Slides were then incubated with secondary anti-rabbit (Vector \#BA-1000) or anti-rat (Vector \#BA-9400) for $1 \mathrm{hr}$ at RT and with AB (avidin and biotinylated peroxidase) solution (Vectastain Elite ABC HRP Kit, Vector, PK-6100) for 30 min. Slides were developed by incubation with peroxidase substrate DAB (Vector SK-4100) until desired stain intensity. Finally, slides were counterstained with hematoxylin, cleared, and mounted with a permanent mounting medium.

Immunohistochemistry for S100A4 (Abcam \#ab27957, 1:300) and Ki67 (Master Diagnostica \#0003110QD, undiluted) was performed using an automated immunostaining platform (Ventana discovery XT, Roche).

\section{Immunoblotting}

Cell pellets or frozen tumor tissues were lysed with JS lysis buffer (50 mM HEPES, $150 \mathrm{mM} \mathrm{NaCl}, 1 \%$ glycerol, 1\% Triton X-100, $1.5 \mathrm{mM} \mathrm{MgCl}$, $5 \mathrm{mM} \mathrm{EGTA),} \mathrm{and} \mathrm{protein} \mathrm{concentrations} \mathrm{were} \mathrm{deter-}$ mined by DC protein assay kit II (Bio-Rad \#5000112). Proteins were separated on house-made SDSPAGE gels and transferred to nitrocellulose membranes (Amersham \#10600003). Membranes were incubated in blocking buffer (5\% milk in TBST) and then with primary antibody overnight at $4^{\circ} \mathrm{C}$. The following primary antibodies and respective dilutions were used: FLAG (Cell Signaling Technology \#2368S, 1:2000), FRA-1 (Santa Cruz \#sc-183, 1:1000; \#sc-605, 1:1000), GFAP (Sigma-Aldrich \#G3893, 1:5000), NF1 (Santa Cruz \#sc-67, 1:500; Bethyl \#A300-140A, 1:1000), OLIG2 (Millipore \#AB9610, 1:2000), VIMENTIN (Cell Signaling Technology \#5741, 1:3000), p-ERK1/2 (T202/Y204) (Cell Signaling Technology, \#9101, 1:2000/3000; Assay Designs \#ADI-905-651, 1:250), ERK1/2 (Cell Signaling Technology, \#9102, 1:1000; Abcam \#ab17942, 1:1000), p-MEK (S217/221) (Cell Signaling Technology, \#9154, 1:500/1000), MEK (Cell Signaling Technology, \#9122 1:1000), CHI3L1 (Qidel \#4815, 1:1000), p85 (Millipore \#06-195, 1:10,000), vinculin (Sigma-Aldrich \#V9131, 1:10,000), and $\alpha$ tubulin (Abcam \#ab7291, 1:10,000). Anti-mouse or rabbit-HRP-conjugated antibodies (Jackson ImmunoResearch, \#115-035-003 and \#111-035-003) were used to detect desired protein by chemiluminescence with ECL Detection Reagent (Amersham, \#RPN2106).

\section{Reverse transcription quantitative PCR}

RNA from NSCs and frozen tissue was isolated with TRIzol reagent (Invitrogen \#15596-026) according to the manufacturer's instructions. For reverse transcription PCR (RT-PCR), 500 ng of total RNA was reverse transcribed using the High Capacity cDNA Reverse Transcription Kit (Applied Biosystems \#4368814). Quantitative PCR was performed using the SYBR Select Master Mix (Applied Biosystems \#4472908) according to the manufacturer's instructions. qPCRs were run and the melting curves of the amplified products were used to determine the specificity of the amplification. The threshold cycle number for the genes analyzed was normalized to GAPDH. Mouse and human primer sequences are listed in Supplementary file 6.

RNA from BTSC cells was prepared using the RNeasy kit or the AllPrep DNA/RNA Protein Mini Kit and used for first-strand cDNA synthesis using random primers and Superscriptlll reverse transcriptase (Life Technologies \#18080-085). Primer sequences used in qRT-PCR with SYBR Green are listed in Supplementary file 6. Quantitative real-time PCR (qRT-PCR) STAT3 and CEBPB were performed using pre-validated TaqMan assays (Applied Biosystems): STAT3: Hs01047580, CEBPB: Hs00270923 and 18S rRNA: Hs99999901.

\section{MTT assay}

Cells were seeded in 96-well culture plates (1000 cells per well, 10 wells per cell line) and grown for 7 days. At each timepoint (days 1, 3, 5, and 7), cell viability was determined by MTT assay. Briefly, $10 \mu \mathrm{L}$ of $5 \mathrm{mg} / \mathrm{mL}$ MTT (Sigma-Aldrich \#M5655) was added to each well and cells were incubated for $4 \mathrm{hr}$ before lysing with a formazan solubilization solution $(10 \%$ SDS in $0.01 \mathrm{M} \mathrm{HCl})$. Colorimetric intensity was quantified using a plate reader at $590 \mathrm{~nm}$. Values were obtained after subtraction of matched blanks (medium only). 


\section{Cell cycle analysis: propidium iodide (PI) staining}

Cells were harvested and washed twice with PBS prior to fixation with $70 \%$ cold ethanol, added drop-wise to the cell pellet while vortexing. Fixed cells were then washed, first with $1 \%$ BSA in PBS, then with PBS only and stained overnight with $50 \mu \mathrm{g} / \mathrm{mL}$ PI (Sigma-Aldrich \#P4170) and $100 \mu \mathrm{g} / \mathrm{mL}$ RNase A (Roche \#10109142001) in PBS. Samples were acquired in a FACSCanto II cytometer (BD Biosciences), and data were analyzed using FlowJo software.

\section{BrdU and EdU incorporation assays}

Cells were pulse-labeled with $10 \mu \mathrm{M}$ BrdU (Sigma-Aldrich \#B9285) for $2 \mathrm{hr}$, harvested and washed twice with PBS prior to fixation with $70 \%$ cold ethanol, and added drop-wise to the cell pellet while vortexing. DNA denaturation was performed by incubating samples for $10 \mathrm{~min}$ on ice with $0.1 \mathrm{M}$ $\mathrm{HCl}$ with $0.5 \%$ Tween-20, and samples were then resuspended in water and boiled at $100^{\circ} \mathrm{C}$ for 10 min. Anti-BrdU-FITC antibody (BD Biosciences \#556028) was incubated according to the manufacturer's protocol. After washing with PBSTB (PBS with $0.5 \%$ Tween-20\% and $1 \%$ BSA), samples were resuspended in $25 \mu \mathrm{g} / \mathrm{mL} \mathrm{PI}$ and $100 \mu \mathrm{g} / \mathrm{mL}$ RNase A diluted in PBS. Samples were acquired in a FACSCanto II cytometer (BD Biosciences), and data were analyzed using FlowJo software.

EdU incorporation was assessed using the EdU-Click594 Cell Proliferation Imaging Kit (Baseclick $\mathrm{GmbH}$ ) according to the manufacturer's instructions. $96 \mathrm{hr}$ after transduction, $2.0 \times 10^{4}$ BTSC 233 cells were seeded on laminin-coated glass coverslips in a 24-well cell culture plate. Pictures were acquired using an Axiovert Microscope (Zeiss).

\section{Immunofluorescence}

Cells were plated in laminin-coated coverslips and fixed with 4\% PFA for $15 \mathrm{~min}$. Cells were then permeabilized with $0.1 \%$ Triton X-100 in $0.2 \%$ BSA, and coverslips were washed and blocked with $10 \%$ donkey serum in $0.2 \%$ BSA for $1 \mathrm{hr}$. The following primary antibodies were incubated overnight at $4^{\circ} \mathrm{C}$ : CD44 (BD Biosciences \#550538, 1:100), GFAP (Millipore \#MAB360, 1:400), and OLIG2 (Millipore \#AB9610, 1:100). Secondary antibodies at 1:400 dilution (from Invitrogen, Alexa-Fluor anti-rabbit-488, anti-mouse-488, and anti-rat 594) were incubated for $1 \mathrm{hr}$ at RT and after washing coverslips were incubated for 4 min with DAPI (1:4000, Sigma-Aldrich \#D8417) and mounted with ProLong Gold Antifade reagent (Invitrogen \#P10144).

Fluorescence signal was quantified as the ratio of green/red pixel area relative to DAPI pixel area per field of view in a total of 36 fields per condition analyzed.

\section{Neurosphere formation assay and limiting dilution analysis}

Neurospheres were dissociated and passed through a $40 \mu \mathrm{m}$ mesh filter to eliminate non-single cells. Decreasing cell densities were plated in ultra-low attachment 96-well plates (Corning \#CLS3474), and fresh medium was added every 3-4 days. The number of positive wells for the presence of spheres was counted 2 weeks after plating. Limiting dilution analysis was performed using ELDA $R$ package (http://bioinf.wehi.edu.au/software/elda/).

\section{RNA-sequencing and analysis on mouse NSCs}

For the p53-null Kras ${ }^{G 12 V}$ NSCs, $1 \mu \mathrm{g}$ of total RNA from the samples was used. cDNA libraries were prepared using the 'QuantSeq 3 'mRNA-Seq Library Prep Kit (FWD) for Illumina' (Lexogen \#015) by following the manufacturer's instructions. Library generation is initiated by reverse transcription with oligo(dT) priming, and a second-strand synthesis is performed from random primers by a DNA polymerase. Primers from both steps contain Illumina-compatible sequences. Adapter-ligated libraries were completed by PCR, applied to an Illumina flow cell for cluster generation, and sequenced on an Illumina HiSeq 2500 by following the manufacturer's protocols. Sequencing read alignment and quantification and differential gene expression analysis was performed in the Bluebee Genomics Platform, a cloud-based service provider (https://www.illumina.com/company/about-us/mergersacquisitions/bluebee.html). Briefly, reads were first trimmed with bbduk from BBTools (BBMap Bushnell B, https://sourceforge.net/projects/bbmap/) to remove adapter sequences and polyA tails. Trimmed reads were aligned to the $\mathrm{GRCm} 38 / \mathrm{mm} 10$ genome assembly with STAR $\vee 2.5$ (Dobin et al., 2013). Read counting was performed with HTSeq (Anders et alo, 2015). The list of 
stem/differentiation markers was compiled by combining a previously described gene list (Sandberg et al., 2013) with other markers (Bazzoli et al., 2012).

For the p53-null shNf1 NSCs, total RNA samples (500 ng) were converted into sequencing libraries with the 'NEBNext Ultra II Directional RNA Library Prep Kit for Illumina' (NEB \#E7760), as recommended by the manufacturer. Briefly, polyA+ fraction is purified and randomly fragmented, converted to double-stranded cDNA, and processed through subsequent enzymatic treatments of end-repair, dA-tailing, and ligation to adapters. Adapter-ligated library is completed by PCR with Illumina PE primers. The resulting purified cDNA libraries were applied to an Illumina flow cell for cluster generation and sequenced on an Illumina NextSeq 550 by following the manufacturer's protocols. We then used the Nextpresso pipeline (Graña et al., 2018) for alignment and quantification.

\section{Osteogenesis differentiation assay}

The osteogenesis differentiation assay was performed using the StemPro Osteogenesis Differentiation Kit (Life Technologies \#A1007201) according to the manufacturer's instructions. Briefly, $5 \times 10^{3}$ cells $/ \mathrm{cm}^{2}$ were seeded on laminin-coated glass coverslips in a 24-well cell culture plate. Cells were incubated in MSC Growth Medium at $37^{\circ} \mathrm{C}, 5 \% \mathrm{CO}_{2}$ for 21 days, replacing the medium every 4 days. Cells were then fixed with $4 \%$ formaldehyde, stained with Alizarin Red S solution (pH 4.2), and mounted on microscope slides. Pictures were acquired using an Axiovert Microscope (Zeiss).

\section{Active Ras pull-down assay}

Active Ras pull-down assay was performed using Active Ras pull-down assay kit (Thermo Fisher Scientific \#16117) according to the manufacturer's instructions. Briefly, cells were grown in $10 \mathrm{~cm}$ plates at $80-90 \%$ confluency in the presence or absence of growth factors (EGF, FGF, and LIF) and lysed with the provided buffer. Lysates were incubated with either GDP or GTP for 30 min followed by precipitation with GST-Raf1-RBD. Western blot was performed with the provided anti-RAS antibody (1:250).

\section{Chromatin preparation and FRA-1 ChIP}

BTSC cells were collected at $2 \times 10^{6}$ cells confluency, washed in PBS, and fixed by addition of $1 \%$ formaldehyde for $20 \mathrm{~min}$ at room temperature. The cells were resuspended in $2 \mathrm{~mL}$ lysis buffer (50 $\mathrm{mM}$ Tris $\mathrm{pH}$ 7.5; $1 \mathrm{mM}$ EDTA pH 8.0; $1 \%$ Triton; 0.1\% Na-deoxycholate; $150 \mathrm{mM} \mathrm{NaCl}$; protease inhibitors) on ice for $20 \mathrm{~min}$. The suspension was sonicated in a cooled Bioruptor Pico (Diagenode) and cleared by centrifugation for $10 \mathrm{~min}$ at 13,000 rpm. The chromatin (DNA) concentration was quantified using NanoDrop (Thermo Scientific), and the sonication efficiency was monitored on an agarose gel. Protein A/G plus-agarose beads (Santa Cruz \#sc-2003) were blocked with sonicated salmon sperm (Thermo Fisher \#AM9680, $200 \mathrm{mg} / \mathrm{mL}$ beads) and BSA (NEB \#B9000S, $250 \mathrm{mg} / \mathrm{mL}$ beads) in dilution buffer (0.5\% NP40; $200 \mathrm{mM} \mathrm{NaCl} ; 50 \mathrm{mM}$ Tris $\mathrm{pH} 8.0$; protease inhibitors) for $2 \mathrm{hr}$ at room temperature. The chromatin was pre-cleared with $80 \mu \mathrm{L}$ of blocked beads for $1 \mathrm{hr}$ at $4^{\circ} \mathrm{C}$. Pre-cleared chromatin was incubated with $5 \mu \mathrm{g}$ of FRA-1 antibody (Santa Cruz \#sc-605) overnight at $4^{\circ} \mathrm{C}$, then with $40 \mu \mathrm{L}$ of blocked beads for further $2 \mathrm{hr}$ at $4^{\circ} \mathrm{C}$. Control mock immunoprecipitation was performed with blocked beads. The beads were washed $1 \times$ with Wash1 $(20 \mathrm{mM}$ Tris pH 7.5; $2 \mathrm{mM}$ EDTA pH 8.0; $1 \%$ Triton; 0.1\% SDS; $150 \mathrm{mM} \mathrm{NaCl}$ ), $1 \times$ with Wash2 (20 mM Tris pH 7.5; 2 mM EDTA $\mathrm{pH} 8.0 ; 1 \%$ Triton; $0.1 \%$ SDS; $500 \mathrm{mM} \mathrm{NaCl}), 1 \times$ with $\mathrm{LiCl}$ Wash $(20 \mathrm{mM}$ Tris $\mathrm{pH}$ 7.5; $1 \mathrm{mM}$ EDTA $\mathrm{pH} 8.0 ; 1 \%$ NP40; $1 \%$ deoxycholate; $250 \mathrm{mM} \mathrm{LiCl})$, and $2 \times$ in TE (10 mM Tris pH 7.5; $1 \mathrm{mM}$ EDTA). The immuno-complexes were eluted by two $15 \mathrm{~min}$ incubations at $30^{\circ} \mathrm{C}$ with $100 \mu \mathrm{L}$ Elution buffer (1\% SDS, $100 \mathrm{mM} \mathrm{NaHCO} 3$ ), and de-crosslinked overnight at $65^{\circ} \mathrm{C}$ in the presence of $10 \mathrm{U}$ Rase $\mathrm{A}$ (Ambion \#AM9780). The immune-precipitated DNA was then purified with the OIAquick PCR purification kit (QIAGEN \#28104) according to the manufacturer's protocol and analyzed by quantitative real-time PCR.

\section{Statistical analysis}

All statistical analyses were performed using $\mathrm{R}$ programming language (3.6.3). Statistical differences between groups were assessed by one-way ANOVA, two-way ANOVA, or unpaired two-tailed Student's t tests unless otherwise specified. 
Kaplan-Meier survival curves were produced with GraphPad Prism, and p-values were generated using the log-rank statistics.

Results are presented as mean \pm standard deviation (SD), and statistical significance was defined as $\mathrm{p} \leq 0.05$ for a $95 \%$ confidence interval.

\section{Code availability}

The accession numbers for data reported in this paper are GEO: GSE137310 (Freiburg BTSCs) and GSE138010 (mouse p53-null Kras ${ }^{G 12 V}$ NSCs). All the R code and data used for analysis and plots generation are available at: https://github.com/squatrim/Marques2020 [copy archived at swh:1:rev: 45e31e7d17f006d2d3a17e66a63449f758bf5998 (Squatrito, 2021)].

\section{Acknowledgements}

We thank Álvaro Ucero for his input on the project and Flora A Díaz for her technical support. We are grateful to Francisco X Real and Scott Lowe for critical input on the manuscript. We thank Pamela Franco for experimental support and discussion. We are grateful to Peter Dirks and Trevor Pugh for providing the processed bulk RNA-seq data of their GSCs dataset. CM was supported by a 'La Caixa' predoctoral fellowship. YD was supported by the Berlin School of Integrative Oncology (BSIO) of the Berlin Charite' Medical University. The GG lab acknowledges funding from MDC, Helmholtz (VH-NG-1153), and ERC (714922). This work was supported by a grant from the Marie Curie International re-integration Grants (MC-IRG), project no. 268303 (to MSC), and by grants from the ISCIII, project PI13/01028, cofounded by the European Regional Development Fund (ERDF), and from the Seve Ballesteros Foundation (to MS).

\section{Additional information}

Funding

\begin{tabular}{|c|c|c|}
\hline Funder & Grant reference number & Author \\
\hline La Caixa Foundation & & Carolina Marques \\
\hline $\begin{array}{l}\text { Berlin School of Integrative } \\
\text { Oncology, Charité - Universi- } \\
\text { tätsmedizin Berlin }\end{array}$ & & Yuliia Dramaretska \\
\hline MDC & VH-NG-1153 & Gaetano Gargiulo \\
\hline European Research Council & 714922 & Gaetano Gargiulo \\
\hline $\begin{array}{l}\text { Marie Curielnternational re-in- } \\
\text { tegration Grants }\end{array}$ & 268303 & Maria Stella Carro \\
\hline Instituto de Salud Carlos III & Pl13/01028 & Massimo Squatrito \\
\hline Seve Ballesteros Foundation & & Massimo Squatrito \\
\hline
\end{tabular}

The funders had no role in study design, data collection and interpretation, or the decision to submit the work for publication.

Author contributions

Carolina Marques, Formal analysis, Investigation, Methodology, Writing - original draft; Thomas Unterkircher, Paula Kroon, Barbara Oldrini, Annalisa Izzo, Roberto Ferrarese, Eva Kling, Investigation; Yuliia Dramaretska, Investigation, Visualization, Writing - original draft; Oliver Schnell, Sven Nelander, Resources; Erwin F Wagner, Latifa Bakiri, Conceptualization, Writing - review and editing; Gaetano Gargiulo, Conceptualization, Formal analysis, Supervision, Funding acquisition, Visualization, Writing - review and editing; Maria Stella Carro, Conceptualization, Resources, Data curation, Formal analysis, Supervision, Funding acquisition, Writing - original draft; Massimo Squatrito, Conceptualization, Resources, Data curation, Formal analysis, Supervision, Funding acquisition, Visualization, Methodology, Writing - original draft 
Author ORCIDs

Carolina Marques (iD) https://orcid.org/0000-0002-8308-5630

Sven Nelander (DiD http://orcid.org/0000-0003-1758-1262

Maria Stella Carro (iD) https://orcid.org/0000-0002-8570-7691

Massimo Squatrito (iD https://orcid.org/0000-0002-4593-3790

Ethics

Animal experimentation: Patient-derived glioblastoma stem cells (BTSCs) from Freiburg University were prepared from tumor specimens under IRB-approved guidelines (\# 407/09_120965). Mice were housed in the specific pathogen-free animal house of the Spanish National Cancer Research Centre under conditions in accordance with the recommendations of the Federation of European Laboratory Animal Science Associations (FELASA). All animal experiments were approved by the Ethical Committee (CElyBA) (\# CBA 31_2019-V2) and performed in accordance with the guidelines stated in the International Guiding Principles for Biomedical Research Involving Animals, developed by the Council for International Organizations of Medical Sciences (CIOMS).

Decision letter and Author response

Decision letter https://doi.org/10.7554/eLife.64846.sa1

Author response https://doi.org/10.7554/eLife.64846.sa2

\section{Additional files}

Supplementary files

- Source code 1. R programming code used for data analysis and plot generation.

- Source data 1. Raw images for western blots.

- Supplementary file 1. Transcriptional subtypes of the brain tumor stem cell (BTSC) lines.

- Supplementary file 2. Genes differentially expressed in brain tumor stem cells (BTSCs) (mesenchymal [MES] versus non-MES) at FDR $<0.05$.

- Supplementary file 3. Master regulator analysis (MRA) results.

- Supplementary file 4. TCGA and CGGA data.

- Supplementary file 5. Gene signatures used for the gene set enrichment analysis (GSEA).

- Supplementary file 6. Primers used in this study.

- Transparent reporting form

Data availability

The accession numbers for data reported in this paper are GEO: GSE137310 (Freiburg BTSCs) and GSE138010 (mouse p53-null KrasG12V NSCs). All the R code and data used for analysis and plots generation is available at: https://github.com/squatrim/Marques2020 (copy archived at https:// archive.softwareheritage.org/swh:1:rev:45e31e7d17f006d2d3a17e66a63449f758bf5998).

The following datasets were generated:

\begin{tabular}{lllll}
\hline Author(s) & Year & Dataset title & Dataset URL & Database and Identifier \\
\hline $\begin{array}{llll}\text { Unterkircher T, } \\
\text { Carro MS }\end{array}$ & 2019 & $\begin{array}{l}\text { Genome-wide analysis of } \\
\text { GBM-derived brain tumor } \\
\text { stem cells-like (BTSCs) }\end{array}$ & $\begin{array}{l}\text { https://www.ncbi.nlm. } \\
\text { nih.gov/geo/query/acc. } \\
\text { cgi?acc=GSE137310 }\end{array}$ & $\begin{array}{l}\text { NCBI Gene Expression } \\
\text { Cmibus, GSE137310 }\end{array}$ \\
\hline Squatrito M & 2020 & $\begin{array}{l}\text { Fosl1 regulates mesenchymal } \\
\text { GBM plasticity }\end{array}$ & $\begin{array}{l}\text { https://www.ncbi.nlm. } \\
\text { nih.gov/geo/query/acc. } \\
\text { cgi?acc=GSE138010 }\end{array}$ & OCBI Gene Expression \\
& & & &
\end{tabular}

The following previously published datasets were used: 


\begin{tabular}{|c|c|c|c|c|}
\hline Author(s) & Year & Dataset title & Dataset URL & $\begin{array}{l}\text { Database and } \\
\text { Identifier }\end{array}$ \\
\hline Squatrito $\mathrm{M}$ & 2019 & $\begin{array}{l}\text { CHROMATIN LANDSCAPES } \\
\text { REVEAL DEVELOPMENTALLY } \\
\text { ENCODED TRANSCRIPTIONAL } \\
\text { STATES THAT DEFINE } \\
\text { GLIOBLASTOMA }\end{array}$ & $\begin{array}{l}\text { https://www.ncbi.nlm. } \\
\text { nih.gov/geo/query/acc. } \\
\text { cgi/GSE119834 }\end{array}$ & $\begin{array}{l}\text { NCBI Gene } \\
\text { Expression Omnibus, } \\
\text { GSE119834 }\end{array}$ \\
\hline Squatrito $\mathrm{M}$ & 2015 & $\begin{array}{l}\text { Precursor States of Brain Tumor } \\
\text { Initiating Cell Lines Are Predictive } \\
\text { of Survival in Xenografts and } \\
\text { Associated With Glioblastoma } \\
\text { Subtypes }\end{array}$ & $\begin{array}{l}\text { https://trace.ddbj.nig.ac. } \\
\text { jp/DRASearch/study? } \\
\text { acc=SRP057855 }\end{array}$ & $\begin{array}{l}\text { DRASearch, SRPO } \\
57855\end{array}$ \\
\hline Squatrito $\mathrm{M}$ & 2015 & $\begin{array}{l}\text { Analysis of mRNA profiles } \\
\text { distinguishes proneural (PN) glioma } \\
\text { stem cells (GSC) from mesenchymal } \\
\text { (Mes) GSCs }\end{array}$ & $\begin{array}{l}\text { https://www.ncbi.nlm. } \\
\text { nih.gov/geo/query/acc. } \\
\text { cgi?acc=GSE67089 }\end{array}$ & $\begin{array}{l}\text { NCBI Gene } \\
\text { Expression Omnibus, } \\
\text { GSE67089 }\end{array}$ \\
\hline Squatrito $\mathrm{M}$ & 2007 & $\begin{array}{l}\text { Expression analyses of } \\
\text { glioblastoma derived neurosphere } \\
\text { cultures }\end{array}$ & $\begin{array}{l}\text { https://www.ncbi.nlm. } \\
\text { nih.gov/geo/query/acc. } \\
\text { cgi?acc=GSE8049 }\end{array}$ & $\begin{array}{l}\text { NCBI Gene } \\
\text { Expression Omnibus, } \\
\text { GSE8049 }\end{array}$ \\
\hline Squatrito $\mathrm{M}$ & 2013 & $\begin{array}{l}\text { A Proneural to Mesenchymal } \\
\text { Transition Mediated by NFkB } \\
\text { Promotes Radiation Resistance in } \\
\text { Glioblastoma (part 1) }\end{array}$ & $\begin{array}{l}\text { https://www.ncbi.nlm. } \\
\text { nih.gov/geo/query/acc. } \\
\text { cgi?acc=GSE49161 }\end{array}$ & $\begin{array}{l}\text { NCBI Gene } \\
\text { Expression Omnibus, } \\
\text { GSE49161 }\end{array}$ \\
\hline Squatrito $\mathrm{M}$ & 2021 & $\begin{array}{l}\text { Gradient of Developmental and } \\
\text { Injury Response transcriptional } \\
\text { states defines functional } \\
\text { vulnerabilities underpinning } \\
\text { glioblastoma heterogeneity. }\end{array}$ & $\begin{array}{l}\text { https://singlecell.broad- } \\
\text { institute.org/single_cell/ } \\
\text { study/SCP503/ }\end{array}$ & $\begin{array}{l}\text { SCP503, single_ } \\
\text { cell }\end{array}$ \\
\hline Squatrito $\mathrm{M}$ & 2019 & $\begin{array}{l}\text { An Integrative Model of Cellular } \\
\text { States, Plasticity, and Genetics for } \\
\text { Glioblastoma. }\end{array}$ & $\begin{array}{l}\text { https://singlecell.broad- } \\
\text { institute.org/single_cell/ } \\
\text { study/SCP393/ }\end{array}$ & single_cell, SCP393 \\
\hline
\end{tabular}

\section{References}

Anders S, Pyl PT, Huber W. 2015. HTSeq-a Python framework to work with high-throughput sequencing data.

Bioinformatics 31:166-169. DOI: https://doi.org/10.1093/bioinformatics/btu638, PMID: 25260700

Andreolas C, Kalogeropoulou M, Voulgari A, Pintzas A. 2008. Fra-1 regulates vimentin during Ha-RAS-induced epithelial mesenchymal transition in human Colon carcinoma cells. International Journal of Cancer 122:17451756. DOI: https://doi.org/10.1002/ijc.23309, PMID: 18098284

Annibali D, Whitfield JR, Favuzzi E, Jauset T, Serrano E, Cuartas I, Redondo-Campos S, Folch G, Gonzàlez-Juncà A, Sodir NM, Massó-Vallés D, Beaulieu M-E, Swigart LB, Mc Gee MM, Somma MP, Nasi S, Seoane J, Evan Gl, Soucek L. 2014. Myc inhibition is effective against glioma and reveals a role for myc in proficient mitosis. Nature Communications 5:1-11. DOI: https://doi.org/10.1038/ncomms5632

Bakiri L, Macho-Maschler S, Custic I, Niemiec J, Guío-Carrión A, Hasenfuss SC, Eger A, Müller M, Beug H, Wagner EF. 2015. Fra-1/AP-1 induces EMT in mammary epithelial cells by modulating Zeb1/2 and tgf $\beta$ expression. Cell Death \& Differentiation 22:336-350. DOI: https://doi.org/10.1038/cdd.2014.157, PMID: 25301070

Bao S, Wu Q, McLendon RE, Hao Y, Shi Q, Hjelmeland AB, Dewhirst MW, Bigner DD, Rich JN. 2006. Glioma stem cells promote radioresistance by preferential activation of the DNA damage response. Nature 444:756760. DOI: https://doi.org/10.1038/nature05236, PMID: 17051156

Basso K, Margolin AA, Stolovitzky G, Klein U, Dalla-Favera R, Califano A. 2005. Reverse engineering of regulatory networks in human B cells. Nature Genetics 37:382-390. DOI: https://doi.org/10.1038/ng1532, PMID: 15778709

Bazzoli E, Pulvirenti T, Oberstadt MC, Perna F, Wee B, Schultz N, Huse JT, Fomchenko El, Voza F, Tabar V, Brennan CW, DeAngelis LM, Nimer SD, Holland EC, Squatrito M. 2012. MEF promotes stemness in the pathogenesis of gliomas. Cell Stem Cell 11:836-844. DOl: https://doi.org/10.1016/j.stem.2012.09.012, PMID: 23217424

Belteki G. 2005. Conditional and inducible transgene expression in mice through the combinatorial use of Cremediated recombination and tetracycline induction. Nucleic Acids Research 33:2765. DOI: https://doi.org/10. 1093/nar/gki559

Bhat KP, Salazar KL, Balasubramaniyan V, Wani K, Heathcock L, Hollingsworth F, James JD, Gumin J, Diefes KL, Kim SH, Turski A, Azodi Y, Yang Y, Doucette T, Colman H, Sulman EP, Lang FF, Rao G, Copray S, Vaillant BD, et al. 2011. The transcriptional coactivator TAZ regulates mesenchymal differentiation in malignant glioma. Genes \& Development 25:2594-2609. DOI: https://doi.org/10.1101/gad.176800.111, PMID: 22190458 
Bhat KPL, Balasubramaniyan V, Vaillant B, Ezhilarasan R, Hummelink K, Hollingsworth F, Wani K, Heathcock L, James JD, Goodman LD, Conroy S, Long L, Lelic N, Wang S, Gumin J, Raj D, Kodama Y, Raghunathan A, Olar $A$, Joshi $K$, et al. 2013. Mesenchymal differentiation mediated by NF- $\kappa B$ promotes radiation resistance in glioblastoma. Cancer Cell 24:331-346. DOI: https://doi.org/10.1016/j.ccr.2013.08.001, PMID: 23993863

Bowman RL, Wang Q, Carro A, Verhaak RG, Squatrito M. 2017. GlioVis data portal for visualization and analysis of brain tumor expression datasets. Neuro-Oncology 19:139-141. DOI: https://doi.org/10.1093/neuonc/ now247, PMID: 28031383

Brennan CW, Verhaak RG, McKenna A, Campos B, Noushmehr H, Salama SR, Zheng S, Chakravarty D, Sanborn JZ, Berman SH, Beroukhim R, Bernard B, Wu CJ, Genovese G, Shmulevich I, Barnholtz-Sloan J, Zou L, Vegesna R, Shukla SA, Ciriello G, et al. 2013. The somatic genomic landscape of glioblastoma. Cell 155:462-477. DOI: https://doi.org/10.1016/j.cell.2013.09.034, PMID: 24120142

Buenrostro JD, Giresi PG, Zaba LC, Chang HY, Greenleaf WJ. 2013. Transposition of native chromatin for fast and sensitive epigenomic profiling of open chromatin, DNA-binding proteins and nucleosome position. Nature Methods 10:1213-1218. DOI: https://doi.org/10.1038/nmeth.2688, PMID: 24097267

Cancer Genome Atlas Research Network. 2008. Comprehensive genomic characterization defines human glioblastoma genes and core pathways. Nature 455:1061-1068. DOI: https://doi.org/10.1038/nature07385, PMID: 18772890

Carro MS, Lim WK, Alvarez MJ, Bollo RJ, Zhao X, Snyder EY, Sulman EP, Anne SL, Doetsch F, Colman H, Lasorella A, Aldape K, Califano A, lavarone A. 2010. The transcriptional network for mesenchymal transformation of brain tumours. Nature 463:318-325. DOI: https://doi.org/10.1038/nature08712, PMID: 20032 975

Casalino L, De Cesare D, Verde P. 2003. Accumulation of Fra-1 in ras-transformed cells depends on both transcriptional autoregulation and MEK-dependent posttranslational stabilization. Molecular and Cellular Biology 23:4401-4415. DOI: https://doi.org/10.1128/MCB.23.12.4401-4415.2003, PMID: 12773579

Castro MA, de Santiago I, Campbell TM, Vaughn C, Hickey TE, Ross E, Tilley WD, Markowetz F, Ponder BA, Meyer KB. 2016. Regulators of genetic risk of breast Cancer identified by integrative network analysis. Nature Genetics 48:12-21. DOI: https://doi.org/10.1038/ng.3458, PMID: 26618344

Ceccarelli M, Barthel FP, Malta TM, Sabedot TS, Salama SR, Murray BA, Morozova O, Newton Y, Radenbaugh A, Pagnotta SM, Anjum S, Wang J, Manyam G, Zoppoli P, Ling S, Rao AA, Grifford M, Cherniack AD, Zhang H, Poisson L, et al. 2016. Molecular profiling reveals biologically discrete subsets and pathways of progression in diffuse glioma. Cell 164:550-563. DOI: https://doi.org/10.1016/j.cell.2015.12.028, PMID: 26824661

Chen J, Li Y, Yu TS, McKay RM, Burns DK, Kernie SG, Parada LF. 2012. A restricted cell population propagates glioblastoma growth after chemotherapy. Nature 488:522-526. DOI: https://doi.org/10.1038/nature11287, PMID: 22854781

Chiappetta G, Ferraro A, Botti G, Monaco M, Pasquinelli R, Vuttariello E, Arnaldi L, Di Bonito M, D'Aiuto G, Pierantoni GM, Fusco A. 2007. FRA-1 protein overexpression is a feature of hyperplastic and neoplastic breast disorders. BMC Cancer 7:17. DOI: https://doi.org/10.1186/1471-2407-7-17, PMID: 17254320

Cooper LA, Gutman DA, Chisolm C, Appin C, Kong J, Rong Y, Kurc T, Van Meir EG, Saltz JH, Moreno CS, Brat DJ. 2012. The tumor microenvironment strongly impacts master transcriptional regulators and gene expression class of glioblastoma. The American Journal of Pathology 180:2108-2119. DOI: https://doi.org/10.1016/j. ajpath.2012.01.040, PMID: 22440258

Cusulin C, Chesnelong C, Bose P, Bilenky M, Kopciuk K, Chan JA, Cairncross JG, Jones SJ, Marra MA, Luchman HA, Weiss S. 2015. Precursor states of brain tumor initiating cell lines are predictive of survival in Xenografts and Associated with Glioblastoma Subtypes. Stem Cell Reports 5:1-9. DOI: https://doi.org/10.1016/j.stemcr. 2015.05.010, PMID: 26095605

Debinski W, Gibo DM. 2005. Fos-related antigen 1 modulates malignant features of glioma cells. Molecular Cancer Research 3:237-249. DOI: https://doi.org/10.1158/1541-7786.MCR-05-0004, PMID: 15831677

Diesch J, Sanij E, Gilan O, Love C, Tran H, Fleming NI, Ellul J, Amalia M, Haviv I, Pearson RB, Tulchinsky E, Mariadason JM, Sieber OM, Hannan RD, Dhillon AS. 2014. Widespread FRA1-Dependent control of mesenchymal transdifferentiation programs in colorectal Cancer cells. PLOS ONE 9:e88950-11. DOI: https:// doi.org/10.1371/journal.pone.0088950

Dobin A, Davis CA, Schlesinger F, Drenkow J, Zaleski C, Jha S, Batut P, Chaisson M, Gingeras TR. 2013. STAR: ultrafast universal RNA-seq aligner. Bioinformatics 29:15-21. DOI: https://doi.org/10.1093/bioinformatics/ bts635, PMID: 23104886

Eferl R, Wagner EF. 2003. AP-1: a double-edged sword in tumorigenesis. Nature Reviews Cancer 3:859-868. DOI: https://doi.org/10.1038/nrc1209, PMID: 14668816

Esnault C, Gualdrini F, Horswell S, Kelly G, Stewart A, East P, Matthews N, Treisman R. 2017. ERK-Induced activation of TCF family of SRF cofactors initiates a chromatin modification cascade associated with transcription. Molecular Cell 65:1081-1095. DOI: https://doi.org/10.1016/j.molcel.2017.02.005, PMID: 282 86024

Fedele V, Dai F, Masilamani AP, Heiland DH, Kling E, Gätjens-Sanchez AM, Ferrarese R, Platania L, Soroush D, Kim H, Nelander S, Weyerbrock A, Prinz M, Califano A, lavarone A, Bredel M, Carro MS. 2017. Epigenetic regulation of ZBTB18 promotes glioblastoma progression. Molecular Cancer Research 15:998-1011. DOI: https://doi.org/10.1158/1541-7786.MCR-16-0494, PMID: 28512252

Fedele M, Cerchia L, Pegoraro S, Sgarra R, Manfioletti G. 2019. Proneural-Mesenchymal transition: phenotypic plasticity to acquire multitherapy resistance in glioblastoma. International Journal of Molecular Sciences $\mathbf{2 0}$ 2746. DOI: https://doi.org/10.3390/ijms20112746 
Fiscon G, Conte F, Paci P. 2018. SWIM tool application to expression data of glioblastoma stem-like cell lines, corresponding primary tumors and conventional glioma cell lines. BMC Bioinformatics 19:436. DOI: https://doi. org/10.1186/s12859-018-2421-x, PMID: 30497369

Fletcher MN, Castro MA, Wang X, de Santiago I, O'Reilly M, Chin SF, Rueda OM, Caldas C, Ponder BA, Markowetz F, Meyer KB. 2013. Master regulators of FGFR2 signalling and breast Cancer risk. Nature Communications 4:2464. DOI: https://doi.org/10.1038/ncomms3464, PMID: 24043118

Friedmann-Morvinski D, Bushong EA, Ke E, Soda Y, Marumoto T, Singer O, Ellisman MH, Verma IM. 2012. Dedifferentiation of neurons and astrocytes by oncogenes can induce gliomas in mice. Science 338:1080-1084. DOI: https://doi.org/10.1126/science.1226929, PMID: 23087000

Gao X-Q, Ge Y-S, Shu Q-H, Ma H-X. 2017. Expression of Fra-1 in human hepatocellular carcinoma and its prognostic significance. Tumor Biology 39:1010428317709635. DOI: https://doi.org/10.1177/ 1010428317709635

Gargiulo G, Cesaroni M, Serresi M, de Vries N, Hulsman D, Bruggeman SW, Lancini C, van Lohuizen M. 2013. In vivo RNAi screen for BMI1 targets identifies TGF- $\beta$ /BMP-ER stress pathways as key regulators of neural- and malignant glioma-stem cell homeostasis. Cancer Cell 23:660-676. DOI: https://doi.org/10.1016/j.ccr.2013.03. 030, PMID: 23680149

Gautier L, Cope L, Bolstad BM, Irizarry RA. 2004. Affy-analysis of affymetrix GeneChip data at the probe level. Bioinformatics 20:307-315. DOI: https://doi.org/10.1093/bioinformatics/btg405, PMID: 14960456

Gel B, Serra E. 2017. karyoploteR: an R/Bioconductor package to plot customizable genomes displaying arbitrary data. Bioinformatics 33:3088-3090. DOI: https://doi.org/10.1093/bioinformatics/btx346, PMID: 28575171

Graña O, Rubio-Camarillo M, Fdez-Riverola F, Pisano DG, Glez-Peña D. 2018. Nextpresso: next generation sequencing expression analysis pipeline. Current Bioinformatics 13:583-591. DOI: https://doi.org/10.2174/ 1574893612666170810153850

Günther HS, Schmidt NO, Phillips HS, Kemming D, Kharbanda S, Soriano R, Modrusan Z, Meissner H, Westphal M, Lamszus K. 2008. Glioblastoma-derived stem cell-enriched cultures form distinct subgroups according to molecular and phenotypic criteria. Oncogene 27:2897-2909. DOI: https://doi.org/10.1038/sj.onc.1210949, PMID: 18037961

Halliday J, Helmy K, Pattwell SS, Pitter KL, LaPlant Q, Ozawa T, Holland EC. 2014. In vivo radiation response of proneural glioma characterized by protective p53 transcriptional program and proneural-mesenchymal shift. PNAS 111:5248-5253. DOI: https://doi.org/10.1073/pnas.1321014111, PMID: 24706837

Hambardzumyan D, Amankulor NM, Helmy KY, Becher OJ, Holland EC. 2009. Modeling adult gliomas using RCAS/t-va technology. Translational Oncology 2:89-95. DOI: https://doi.org/10.1593/tlo.09100, PMID: 1 9412424

Hara T, Chanoch-Myers R, Mathewson ND, Myskiw C, Atta L, Bussema L, Eichhorn SW, Greenwald AC, Kinker GS, Rodman C, Gonzalez Castro LN, Wakimoto H, Rozenblatt-Rosen O, Zhuang X, Fan J, Hunter T, Verma IM, Wucherpfennig KW, Regev A, Suvà ML, et al. 2021. Interactions between Cancer cells and immune cells drive transitions to mesenchymal-like states in glioblastoma. Cancer Cell 39:779-792. DOI: https://doi.org/10.1016/j. ccell.2021.05.002, PMID: 34087162

Hasenfuss SC, Bakiri L, Thomsen MK, Hamacher R, Wagner EF. 2014. Activator protein 1 transcription factor Fosrelated antigen 1 (Fra-1) is dispensable for murine liver fibrosis, but modulates xenobiotic metabolism. Hepatology 59:261-273. DOI: https://doi.org/10.1002/hep.26518, PMID: 23703832

Hennig BP, Velten L, Racke I, Tu CS, Thoms M, Rybin V, Besir H, Remans K, Steinmetz LM. 2018. Large-Scale Low-Cost NGS library preparation using a robust Tn5 purification and tagmentation protocol. G3: Genes, Genomes, Genetics 8:79-89. DOI: https://doi.org/10.1534/g3.117.300257

Holland EC, Celestino J, Dai C, Schaefer L, Sawaya RE, Fuller GN. 2000. Combined activation of ras and akt in neural progenitors induces glioblastoma formation in mice. Nature Genetics 25:55-57. DOI: https://doi.org/10. 1038/75596, PMID: 10802656

Koschmann C, Calinescu AA, Nunez FJ, Mackay A, Fazal-Salom J, Thomas D, Mendez F, Kamran N, Dzaman M, Mulpuri L, Krasinkiewicz J, Doherty R, Lemons R, Brosnan-Cashman JA, Li Y, Roh S, Zhao L, Appelman H, Ferguson D, Gorbunova V, et al. 2016. ATRX loss promotes tumor growth and impairs nonhomologous end joining DNA repair in glioma. Science Translational Medicine 8:328ra28. DOI: https://doi.org/10.1126/ scitranslmed.aac8228, PMID: 26936505

Lambert SA, Jolma A, Campitelli LF, Das PK, Yin Y, Albu M, Chen X, Taipale J, Hughes TR, Weirauch MT. 2018. The human transcription factors. Cell 172:650-665. DOI: https://doi.org/10.1016/j.cell.2018.01.029, PMID: 2 9425488

Langmead B, Salzberg SL. 2012. Fast gapped-read alignment with bowtie 2. Nature Methods 9:357-359. DOI: https://doi.org/10.1038/nmeth.1923, PMID: 22388286

Lau EY, Lo J, Cheng BY, Ma MK, Lee JM, Ng JK, Chai S, Lin CH, Tsang SY, Ma S, Ng IO, Lee TK. 2016. CancerAssociated fibroblasts regulate Tumor-Initiating cell plasticity in hepatocellular carcinoma through c-Met/FRA1/ HEY1 signaling. Cell Reports 15:1175-1189. DOI: https://doi.org/10.1016/j.celrep.2016.04.019, PMID: 27134167

Li T, Fu J, Zeng Z, Cohen D, Li J, Chen Q, Li B, Liu XS. 2020. TIMER2.0 for analysis of tumor-infiltrating immune cells. Nucleic Acids Research 48:W509-W514. DOI: https://doi.org/10.1093/nar/gkaa407

Liu H, Ren G, Wang T, Chen Y, Gong C, Bai Y, Wang B, Qi H, Shen J, Zhu L, Qian C, Lai M, Shao J. 2015. Aberrantly expressed Fra-1 by IL-6/STAT3 transactivation promotes colorectal Cancer aggressiveness through epithelial-mesenchymal transition. Carcinogenesis 36:459-468. DOI: https://doi.org/10.1093/carcin/bgv017, PMID: 25750173 
Louis DN, Perry A, Reifenberger G, von Deimling A, Figarella-Branger D, Cavenee WK, Ohgaki H, Wiestler OD, Kleihues P, Ellison DW. 2016. The 2016 world health organization classification of tumors of the central nervous system: a summary. Acta Neuropathologica 131:803-820. DOI: https://doi.org/10.1007/s00401-016-1545-1, PMID: 27157931

Love MI, Huber W, Anders S. 2014. Moderated estimation of fold change and dispersion for RNA-seq data with DESeq2. Genome Biology 15:550. DOI: https://doi.org/10.1186/s13059-014-0550-8, PMID: 25516281

Mack SC, Singh I, Wang X, Hirsch R, Wu Q, Villagomez R, Bernatchez JA, Zhu Z, Gimple RC, Kim LJY, Morton A, Lai S, Qiu Z, Prager BC, Bertrand KC, Mah C, Zhou W, Lee C, Barnett GH, Vogelbaum MA, et al. 2019. Chromatin landscapes reveal developmentally encoded transcriptional states that define human glioblastoma. Journal of Experimental Medicine 216:1071-1090. DOI: https://doi.org/10.1084/jem.20190196, PMID: 309484 95

Mani SA, Guo W, Liao MJ, Eaton EN, Ayyanan A, Zhou AY, Brooks M, Reinhard F, Zhang CC, Shipitsin M, Campbell LL, Polyak K, Brisken C, Yang J, Weinberg RA. 2008. The epithelial-mesenchymal transition generates cells with properties of stem cells. Cell 133:704-715. DOI: https://doi.org/10.1016/j.cell.2008.03.027, PMID: 1 8485877

Mansuy IM, Bujard H. 2000. Tetracycline-regulated gene expression in the brain. Current Opinion in Neurobiology 10:593-596. DOl: https://doi.org/10.1016/S0959-4388(00)00127-6, PMID: 11084322

Mao P, Joshi K, Li J, Kim SH, Li P, Santana-Santos L, Luthra S, Chandran UR, Benos PV, Smith L, Wang M, Hu B, Cheng SY, Sobol RW, Nakano I. 2013. Mesenchymal glioma stem cells are maintained by activated glycolytic metabolism involving aldehyde dehydrogenase 1a3. PNAS 110:8644-8649. DOI: https://doi.org/10.1073/pnas. 1221478110, PMID: 23650391

Matsuo K, Owens JM, Tonko M, Elliott C, Chambers TJ, Wagner EF. 2000. Fosl1 is a transcriptional target of c-Fos during osteoclast differentiation. Nature Genetics 24:184-187. DOI: https://doi.org/10.1038/72855, PMID: 10655067

McCormick F. 1990. GAP as ras effector or negative regulator? Molecular Carcinogenesis 3:185-187. DOI: https://doi.org/10.1002/mc.2940030404, PMID: 2206281

Muñoz DM, Tung T, Agnihotri S, Singh S, Guha A, Zadeh G, Hawkins C. 2013. Loss of p53 cooperates with K-ras activation to induce glioma formation in a region-independent manner. Glia 61:1862-1872. DOI: https://doi. org/10.1002/glia.22563, PMID: 24038521

Neftel C, Laffy J, Filbin MG, Hara T, Shore ME, Rahme GJ, Richman AR, Silverbush D, Shaw ML, Hebert CM, Dewitt J, Gritsch S, Perez EM, Gonzalez Castro LN, Lan X, Druck N, Rodman C, Dionne D, Kaplan A, Bertalan MS, et al. 2019. An integrative model of cellular states, plasticity, and genetics for glioblastoma. Cell 178:835849. DOI: https://doi.org/10.1016/j.cell.2019.06.024

Oldrini B, Curiel-García Á, Marques C, Matia V, Uluçkan Ö, Graña-Castro O, Torres-Ruiz R, Rodriguez-Perales S, Huse JT, Squatrito M. 2018. Somatic genome editing with the RCAS-TVA-CRISPR-Cas9 system for precision tumor modeling. Nature Communications 9:1466. DOI: https://doi.org/10.1038/s41467-018-03731-w, PMID: 2 9654229

Ozawa T, Riester M, Cheng YK, Huse JT, Squatrito M, Helmy K, Charles N, Michor F, Holland EC. 2014. Most human non-GCIMP glioblastoma subtypes evolve from a common proneural-like precursor glioma. Cancer Cell 26:288-300. DOI: https://doi.org/10.1016/j.ccr.2014.06.005, PMID: 25117714

Patel AP, Tirosh I, Trombetta JJ, Shalek AK, Gillespie SM, Wakimoto H, Cahill DP, Nahed BV, Curry WT, Martuza RL, Louis DN, Rozenblatt-Rosen O, Suvà ML, Regev A, Bernstein BE. 2014. Single-cell RNA-seq highlights intratumoral heterogeneity in primary glioblastoma. Science 344:1396-1401. DOI: https://doi.org/10.1126/ science.1254257, PMID: 24925914

Phillips HS, Kharbanda S, Chen R, Forrest WF, Soriano RH, Wu TD, Misra A, Nigro JM, Colman H, Soroceanu L, Williams PM, Modrusan Z, Feuerstein BG, Aldape K. 2006. Molecular subclasses of high-grade glioma predict prognosis, delineate a pattern of disease progression, and resemble stages in neurogenesis. Cancer Cell 9 : 157-173. DOI: https://doi.org/10.1016/j.ccr.2006.02.019, PMID: 16530701

Ramírez F, Ryan DP, Grüning B, Bhardwaj V, Kilpert F, Richter AS, Heyne S, Dündar F, Manke T. 2016. deepTools2: a next generation web server for deep-sequencing data analysis. Nucleic Acids Research 44: W160-W165. DOI: https://doi.org/10.1093/nar/gkw257

Ricci-Vitiani L, Pallini R, Larocca LM, Lombardi DG, Signore M, Pierconti F, Petrucci G, Montano N, Maira G, De Maria R. 2008. Mesenchymal differentiation of glioblastoma stem cells. Cell Death \& Differentiation 15:14911498. DOI: https://doi.org/10.1038/cdd.2008.72, PMID: 18497759

Richards LM, Whitley OKN, MacLeod G, Cavalli FMG, Coutinho FJ, Jaramillo JE, Svergun N, Riverin M, Croucher DC, Kushida M, Yu K, Guilhamon P, Rastegar N, Ahmadi M, Bhatti JK, Bozek DA, Li N, Lee L, Che C, Luis E, et al. 2021. Gradient of developmental and injury response transcriptional states defines functional vulnerabilities underpinning glioblastoma heterogeneity. Nature Cancer 2:157-173. DOI: https://doi.org/10. 1038/s43018-020-00154-9

Ritchie ME, Phipson B, Wu D, Hu Y, Law CW, Shi W, Smyth GK. 2015. Limma powers differential expression analyses for RNA-sequencing and microarray studies. Nucleic Acids Research 43:e47. DOI: https://doi.org/10. 1093/nar/gkv007, PMID: 25605792

Sandberg CJ, Altschuler G, Jeong J, Strømme KK, Stangeland B, Murrell W, Grasmo-Wendler UH, Myklebost O, Helseth E, Vik-Mo EO, Hide W, Langmoen IA. 2013. Comparison of glioma stem cells to neural stem cells from the adult human brain identifies dysregulated wnt- signaling and a fingerprint associated with clinical outcome. Experimental Cell Research 319:2230-2243. DOI: https://doi.org/10.1016/j.yexcr.2013.06.004, PMID: 2379193 
Schep AN, Wu B, Buenrostro JD, Greenleaf WJ. 2017. chromVAR: inferring transcription-factor-associated accessibility from single-cell epigenomic data. Nature Methods 14:975-978. DOI: https://doi.org/10.1038/ nmeth.4401, PMID: 28825706

Schmitt MJ, Company C, Dramaretska Y, Barozzi I, Göhrig A, Kertalli S, Großmann M, Naumann H, SanchezBailon MP, Hulsman D, Glass R, Squatrito M, Serresi M, Gargiulo G. 2021. Phenotypic mapping of pathologic Cross-Talk between glioblastoma and innate immune cells by synthetic genetic tracing. Cancer Discovery 11: 754-777. DOI: https://doi.org/10.1158/2159-8290.CD-20-0219, PMID: 33361384

Serresi M, Kertalli S, Li L, Schmitt MJ, Dramaretska Y, Wierikx J, Hulsman D, Gargiulo G. 2021. Functional antagonism of chromatin modulators regulates epithelial-mesenchymal transition. Science Advances 7: eabd7974. DOI: https://doi.org/10.1126/sciadv.abd7974, PMID: 33627422

Sottoriva A, Spiteri I, Piccirillo SG, Touloumis A, Collins VP, Marioni JC, Curtis C, Watts C, Tavaré S. 2013. Intratumor heterogeneity in human glioblastoma reflects Cancer evolutionary dynamics. PNAS 110:4009-4014. DOI: https://doi.org/10.1073/pnas.1219747110, PMID: 23412337

Squatrito M. 2021. marques2020. Software Heritage. swh:1:rev:45e31e7d17f006d2d3a17e66a63449f758bf5998. https://archive.softwareheritage.org/swh:1:dir:9a190c31dcd2e5c1208d3701aedd95ee40cd3a52; origin=https:// github.com/squatrim/marques2020; visit=swh:1:snp:d5d44f19da835e0a371 b432aa30cf3dedc117fa1; anchor=swh:1: rev:45e31e7d17f006d2d3a17e66a63449f758bf5998

Subramanian A, Tamayo P, Mootha VK, Mukherjee S, Ebert BL, Gillette MA, Paulovich A, Pomeroy SL, Golub TR, Lander ES, Mesirov JP. 2005. Gene set enrichment analysis: a knowledge-based approach for interpreting genome-wide expression profiles. PNAS 102:15545-15550. DOI: https://doi.org/10.1073/pnas.0506580102, PMID: 16199517

Suvà ML, Rheinbay E, Gillespie SM, Patel AP, Wakimoto H, Rabkin SD, Riggi N, Chi AS, Cahill DP, Nahed BV, Curry WT, Martuza RL, Rivera MN, Rossetti N, Kasif S, Beik S, Kadri S, Tirosh I, Wortman I, Shalek AK, et al. 2014. Reconstructing and reprogramming the tumor-propagating potential of glioblastoma stem-like cells. Cell 157:580-594. DOI: https://doi.org/10.1016/j.cell.2014.02.030, PMID: 24726434

Tam WL, Lu H, Buikhuisen J, Soh BS, Lim E, Reinhardt F, Wu ZJ, Krall JA, Bierie B, Guo W, Chen X, Liu XS, Brown M, Lim B, Weinberg RA. 2013. Protein kinase $C \alpha$ is a central signaling node and therapeutic target for breast Cancer stem cells. Cancer Cell 24:347-364. DOI: https://doi.org/10.1016/j.ccr.2013.08.005, PMID: 24029232

Tam WL, Weinberg RA. 2013. The epigenetics of epithelial-mesenchymal plasticity in Cancer. Nature Medicine 19: 1438-1449. DOI: https://doi.org/10.1038/nm.3336, PMID: 24202396

Tso CL, Shintaku P, Chen J, Liu Q, Liu J, Chen Z, Yoshimoto K, Mischel PS, Cloughesy TF, Liau LM, Nelson SF. 2006. Primary glioblastomas express mesenchymal stem-like properties. Molecular Cancer Research 4:607-619. DOI: https://doi.org/10.1158/1541-7786.MCR-06-0005, PMID: 16966431

Uhrbom L, Dai C, Celestino JC, Rosenblum MK, Fuller GN, Holland EC. 2002. Ink4a-Arf loss cooperates with KRas activation in astrocytes and neural progenitors to generate glioblastomas of various morphologies depending on activated akt. Cancer Research 62:5551-5558. PMID: 12359767

Usui A, Hoshino I, Akutsu Y, Sakata H, Nishimori T, Murakami K, Kano M, Shuto K, Matsubara H. 2012. The molecular role of Fra-1 and its prognostic significance in human esophageal squamous cell carcinoma. Cancer 118:3387-3396. DOI: https://doi.org/10.1002/cncr.26652, PMID: 22028113

Vallejo A, Perurena N, Guruceaga E, Mazur PK, Martinez-Canarias S, Zandueta C, Valencia K, Arricibita A, Gwinn D, Sayles LC, Chuang CH, Guembe L, Bailey P, Chang DK, Biankin A, Ponz-Sarvise M, Andersen JB, Khatri P, Bozec A, Sweet-Cordero EA, et al. 2017. An integrative approach unveils FOSL1 as an oncogene vulnerability in KRAS-driven lung and pancreatic Cancer. Nature Communications 8:14294. DOI: https://doi.org/10.1038/ ncomms14294, PMID: 28220783

Varn FS, Johnson KC, Wade TE, Malta TM, Sabedot TS, Barthel FP, Kim H, Ahmed N, Datta I, Barnholtz-Sloan JS, Bakas S, D'Angelo F, Gan HK, Garofano L, Huse JT, Khasraw M, Kocakavuk E, Migliozzi S, Ormond DR, Paek SH, et al. 2021. Longitudinal analysis of diffuse glioma reveals cell state dynamics at recurrence associated with changes in genetics and the microenvironment. bioRxiv. DOI: https://doi.org/10.1101/2021.05.03.442486

Verde P, Casalino L, Talotta F, Yaniv M, Weitzman JB. 2007. Deciphering AP-1 function in Tumorigenesis: fraternizing on target promoters. Cell Cycle 6:2633-2639. DOI: https://doi.org/10.4161/cc.6.21.4850, PMID: 17 957143

Verhaak RG, Hoadley KA, Purdom E, Wang V, Qi Y, Wilkerson MD, Miller CR, Ding L, Golub T, Mesirov JP, Alexe G, Lawrence M, O'Kelly M, Tamayo P, Weir BA, Gabriel S, Winckler W, Gupta S, Jakkula L, Feiler HS, et al. 2010. Integrated genomic analysis identifies clinically relevant subtypes of glioblastoma characterized by abnormalities in PDGFRA, IDH1, EGFR, and NF1. Cancer Cell 17:98-110. DOI: https://doi.org/10.1016/j.ccr. 2009.12.020, PMID: 20129251

Wang J, Cazzato E, Ladewig E, Frattini V, Rosenbloom DIS, Zairis S, Abate F, Liu Z, Elliott O, Shin Y-J, Lee J-K, Lee I-H, Park W-Y, Eoli M, Blumberg AJ, Lasorella A, Nam D-H, Finocchiaro G, lavarone A, Rabadan R. 2016. Clonal evolution of glioblastoma under therapy. Nat Genet 48:768-776. DOI: https://doi.org/10.1038/ng.3590

Wang Q, Hu B, Hu X, Kim H, Squatrito M, Scarpace L, deCarvalho AC, Lyu S, Li P, Li Y, Barthel F, Cho HJ, Lin YH, Satani N, Martinez-Ledesma E, Zheng S, Chang E, Sauvé CG, Olar A, Lan ZD, et al. 2017. Tumor evolution of Glioma-Intrinsic gene expression subtypes associates with immunological changes in the microenvironment. Cancer Cell 32:42-56. DOI: https://doi.org/10.1016/j.ccell.2017.06.003, PMID: 28697342

Wang L, Babikir H, Müller S, Yagnik G, Shamardani K, Catalan F, Kohanbash G, Alvarado B, Di Lullo E, Kriegstein A, Shah S, Wadhwa H, Chang SM, Phillips JJ, Aghi MK, Diaz AA. 2019. The phenotypes of proliferating glioblastoma cells reside on a single Axis of variation. Cancer Discovery 9:1708-1719. DOI: https://doi.org/10. 1158/2159-8290.CD-19-0329 
Wu J, Ji A, Wang X, Zhu Y, Yu Y, Lin Y, Liu Y, Li S, Liang Z, Xu X, Zheng X, Xie L. 2015. MicroRNA-195-5p, a new regulator of Fra-1, suppresses the migration and invasion of prostate Cancer cells. Journal of Translational Medicine 13:289. DOI: https://doi.org/10.1186/s12967-015-0650-6, PMID: 26337460

Wu Y, Fletcher M, Gu Z, Wang Q, Costa B, Bertoni A, Man KH, Schlotter M, Felsberg J, Mangei J, Barbus M, Gaupel AC, Wang W, Weiss T, Eils R, Weller M, Liu H, Reifenberger G, Korshunov A, Angel P, et al. 2020. Glioblastoma epigenome profiling identifies SOX10 as a master regulator of molecular tumour subtype. Nature Communications 11:6434. DOI: https://doi.org/10.1038/s41467-020-20225-w, PMID: 33339831

Xu H, Jin X, Yuan Y, Deng P, Jiang L, Zeng X, Li XS, Wang ZY, Chen QM. 2017. Prognostic value from integrative analysis of transcription factors c-Jun and Fra-1 in oral squamous cell carcinoma: a multicenter cohort study. Scientific Reports 7:7522. DOI: https://doi.org/10.1038/s41598-017-05106-5, PMID: 28790303

Ye X, Tam WL, Shibue T, Kaygusuz Y, Reinhardt F, Ng Eaton E, Weinberg RA. 2015. Distinct EMT programs control normal mammary stem cells and tumour-initiating cells. Nature 525:256-260. DOl: https://doi.org/10. 1038/nature14897, PMID: 26331542

Younesy H, Nielsen CB, Lorincz MC, Jones SJ, Karimi MM, Möller T. 2016. ChAsE: chromatin analysis and exploration tool. Bioinformatics 32:3324-3326. DOI: https://doi.org/10.1093/bioinformatics/btw382, PMID: 27378294

Yu G, Wang L-G, Han Y, He Q-Y. 2012. clusterProfiler: an R package for comparing biological themes among gene clusters. OMICS: A Journal of Integrative Biology 16:284-287. DOI: https://doi.org/10.1089/omi.2011. 0118

Zhang Y, Liu T, Meyer CA, Eeckhoute J, Johnson DS, Bernstein BE, Nusbaum C, Myers RM, Brown M, Li W, Liu XS. 2008. Model-based analysis of ChIP-Seq (MACS). Genome Biology 9:R137. DOI: https://doi.org/10.1186/ gb-2008-9-9-r137, PMID: 18798982

Zhao Z, Meng F, Wang W, Wang Z, Zhang C, Jiang T. 2017. Comprehensive RNA-seq transcriptomic profiling in the malignant progression of gliomas. Scientific Data 4:1-7. DOI: https://doi.org/10.1038/sdata.2017.24 